\title{
Modernising the Constitution - An Armed Forces Act
}

\author{
Graham McBain ${ }^{1,2}$ \\ ${ }^{1}$ Peterhouse, Cambridge, UK \\ ${ }^{2}$ Harvard Law School, USA \\ Correspondence: Graham McBain, 21 Millmead Terrace, Guildford, Surrey GU2 4AT, UK. E-mail: \\ gsmcbain@aol.com
}

Received: January 2, 2022 Accepted: February 6, 2022 Online Published: February 9, 2022

doi:10.5539/ilr.v11n1p197 URL: https://doi.org/10.5539/ilr.v11n1p197

\section{INTRODUCTION}

A prior series of articles has proposed the consolidation of c. 150 pieces of constitutional legislation relating to the UK into 4 Acts viz. a:

- Crown Act

- Parliament Act

- Courts Act

- Government Act. $^{1}$

These can, then, be consolidated into 1 Constitution Act. ${ }^{2}$ Another article (in two parts) has argued for another $\mathrm{c}$. 150 pieces of constitutional legislation which relate to foreign affairs being consolidated into a British Territories and Foreign Affairs Act (a 'BTFRA'), ${ }^{3}$ which Act can - in due course - also, be consolidated into a Constitution Act. The effect of the above would be to remove a large number of obsolete Crown prerogatives (about $85 \%$ are obsolete anyway) and to consolidate c. 300 (piecemeal) Acts of Parliament into 5 Acts. Then, into one Constitution Act. $^{4}$

All the above have considered a large number of Crown prerogatives which still exist. However, others still remain. This is especially so in the field of military law. That is, the law relating to the armed forces. A number of these have already been considered in the context of a Crown Act and a Government Act. This article reviews those that remain.

\section{In conclusion, this article looks at remaining Crown prerogatives in the field of military law.}

\section{LEGAL TEXTS}

When considering military law, there have been a number of legal texts down the centuries (see Appendix $\boldsymbol{C}$ ). However, the (vast) majority of these are obsolete due to military law now (mainly) being in the form of (modern) legislation. Also, due to the re-organisation of the armed forces. Apart from these, there are many legal texts relating to constitutional law. ${ }^{5}$ There are, also, various editions of Halsbury, Laws of England ${ }^{6}$ and Halsbury, Statutes of England. Further, it is useful to refer to the following texts when describing the legal history of the matters discussed in this article:

- Chitty Jun, $A$ Treatise of the Law of the Prerogatives of the Crown (1820) ('Chitty'); ${ }^{7}$

- Bowyer, Commentaries on Constitutional Law (1846)('Bowyer'); ${ }^{8}$

- Maitland, English Constitutional History (1908) ('Maitland');

\footnotetext{
${ }^{1}$ GS McBain, Modernising the Constitution - A Crown Act (2021) International Law Research ('ILR'), vol 10, no 1, pp 33-100. Ibid, Modernising the Constitution - A Parliament Act (2021) ILR, vol 10, no 1, pp 101-84. Ibid, Modernising the Constitution - A Courts Act (2021) ILR, vol 10, no 1, pp 195-248. Ibid, Modernising the Constitution - Quangos (2022) ILR, vol 11, no 1, pp 1-61.

${ }^{2}$ That said, it may be better to leave the Courts Act - which is more likely to be amended on a regular basis - distinct.

${ }^{3}$ GS McBain, Modernising the Constitution - British Territories and Foreign Relations Act: Parts 1 and 2 (2021) ILR, vol 11, no 1, pp 117$61 \& 162-96$.

${ }^{4}$ As with a Courts Act, it would seem best to leave an Armed Forces Act (or Code) distinct. Possibly, also, a Government Act.

${ }^{5}$ For an attempt to list the same, see McBain, n 1 (Crown Act), pp 62-8.

${ }^{6}$ Halsbury, Laws of England $\left(1^{\text {st }}\right.$ ed, $1907-17$ with supp; $2^{\text {nd }}$ ed, 1931-42 with supp; $3^{\text {rd }}$ ed, $1953-63$ with supp; $4^{\text {th }}$ ed, 1973 with supp; $5^{\text {th }}$ ed, 2008 with supp). The relevant volumes on constitutional law in the $1^{\text {st }}$ ed were vols $6 \& 7$.

${ }^{7} \mathrm{~J}$ Chitty Jun, A Treatise of the Law of the Prerogatives of the Crown (1820).

${ }^{8} \mathrm{G}$ Bowyer, Commentaries on the Constitutional Law of England (1846).

${ }^{9} \mathrm{FW}$ Maitland, English Constitutional History $\left(1^{\text {st }}\right.$ ed, 1908) (it contained a course of lectures delivered in 1887-8 at Cambridge university).
} 
- $\quad$ Feilden, Short Constitutional History of England (1922)('Feilden'); $;^{10}$

- Chalmers \& Asquith, Outlines of Constitutional Law (1922) ('Chalmers'); ${ }^{11}$

- $\quad$ Wade \& Phillips, Constitutional Law (1 ${ }^{\text {st }}$ ed, 1931) ('Wade'); ${ }^{12}$

- $\quad$ Ridges, Constitutional Law of England (1934)('Ridges'); ${ }^{13}$

- Anson, The Law and Custom of the Constitution (1935)('Anson'); ${ }^{14}$

- Dicey, Introduction to the Study of the Law of the Constitution (1948 ed) ('Dicey'), ${ }^{15}$

- $\quad$ Plucknett, Taswell-Langmead's Constitutional History (1960)('Plucknett'); ${ }^{16}$

- Jennings, Cabinet Government (1969) ('Jennings'); ${ }^{17}$

- $\quad$ Brazier, Constitutional Practice (1994)('Brazier'); ${ }^{18}$

- $\quad$ De Smith \& Brazier, Constitutional and Administrative Law (1998)('DeSmith'); ${ }^{19}$

- $\quad$ Munro, Studies in Constitutional Law (1999)('Munro'); ${ }^{20}$

- $\quad$ Leyland, The Constitution of the UK (2012)('Leyland'); ${ }^{21}$

- Bradley et al, Constitutional and Administrative Law (2018)('Bradley'), ${ }^{22}$

- $\quad$ Barnett, Constitutional and Administrative Law (2020)('Barnett'). ${ }^{23}$

In particular, Chitty is useful to indicate the state of the law in 1820, Wade that in 1931 and Bradley that in 2018. Prior to Chitty (in 1820), there were various texts dealing with the Crown prerogative;

- $\quad$ Staunford, An Exposition of the King's Prerogative (1567-1607) ('Staunford'); ${ }^{24}$

- $\quad$ Coke, Institutes of the Laws of England (1628-41) ('Coke'); ${ }^{25}$

- Hale, Prerogatives of the King (written 1640's) ('Hale'), ${ }^{26}$

- Blackstone, Commentaries on the Laws of England (1765-9 ('Blackstone'), ${ }^{27}$

- $\quad$ Bacon, A New Abridgment of the Law (5 $5^{\text {th }}$ ed, 1795-8) ('Bacon'). ${ }^{28}$

\section{AN ARMED FORCES ACT - ARMED FORCES CODE}

A previous article on a Government Act has asserted that it would be very beneficial (and, doubtless, save much money for the armed forces and the taxpayer) if c. 106 Acts of Parliament which govern the armed forces at present were consolidated into 1 Armed Forces Act (or Code, an 'AFC'). Such would be easily achieved by MOD draftsmen using the (useful) Armed Forces Act 2006 as a base. The 106 pieces of legislation are set out in Appendix A. In this article, further points may be noted in respect of this military legislation:

- $\quad$ Armed Forces Pensions. This material does not need to be in primary legislation. It would be more useful for it to be in a SI, enabling easier amendment;

\footnotetext{
${ }^{10}$ HC Feilden, Short Constitutional History of England (1922).

${ }^{11}$ D Chalmers \& C Asquith, Outlines of Constitutional Law (1922). Also, $5^{\text {th }}$ ed (in 1936, edited by C Asquith).

${ }^{12}$ ECS Wade \& GC Phillips, Constitutional Law (1 $1^{\text {st }}$ ed, 1931).

${ }^{13}$ EW Ridges, Constitutional Law of England (5 ${ }^{\text {th }}$ ed, 1934, ed AB Keith).

${ }^{14}$ WR Anson, The Law and Custom of the Constitution (ed AB Keith, $4^{\text {th }}$ ed, 1935).

15 The first edition was in 1885. Reference in this article is to AV Dicey, Introduction to the Study of the Law of the Constitution (9 $9^{\text {th }}$ ed, 1948 ed, ed ECS Wade).

${ }^{16}$ TFT Plucknett, Taswell-Langmead's English Constitutional History (1960).

${ }^{17}$ I Jennings, Cabinet Government ( $9^{\text {th }}$ ed, 1969, ed ECS Wade).

${ }^{18}$ R Brazier, Constitutional Practice ( $2^{\text {nd }}$ ed, 1994).

${ }^{19} \mathrm{~S}$ De Smith \& R Brazier, Constitutional and Administrative Law (1998).

${ }^{20}$ CR Munro, Studies in Constitutional Law (2 ${ }^{\text {nd }}$ ed, 1999).

${ }^{21}$ P Leyland, The Constitution of the United Kingdom (2012).

${ }^{22}$ AW Bradley, KD Ewing \& CJS Knight, Constitutional and Administrative Law (2018). This text is the successor to Wade, see $\mathrm{n} 12$.

${ }^{23} \mathrm{H}$ Barnett, Constitutional and Administrative Law (13 ${ }^{\text {th }}$ ed, 2020).

${ }^{24} \mathrm{~W}$ Staunford, Exposition of the Kinges Prerogative collected out of the great Abridgement of Fitzherbert, and other olde writers of the lawes of England; [with] the process to the same prerogative appertayning.' The first edition was in 1567 . Later editions were published in 1567 , 1568, 1573, 1577, 1568-77, 1590 and 1607. For texts prior to Staunford dealing with constitutional law see McBain, n 1 (Crown), pp 62-3.

${ }^{25}$ E Coke, Institutes of the Laws of England (W Clarke \& Sons, London, last ed, 1824).

${ }^{26}$ DEC Yale (ed), Sir Matthew Hale's Prerogatives of the King, Selden Society, vol 92 (London, 1976).

${ }^{27}$ W Blackstone, Commentaries on the Laws of England (Oxford, Clarendon Press, $1^{\text {st }}$ ed, 1765-9, University of Chicago Press rep 1979).

${ }^{28} \mathrm{M}$ Bacon, A New Abridgment of the Law (5th ed, 7 vols, 1798). Volume 5 (prerogative) contains material on the Crown prerogative. The first edition of Bacon was in 1736-66 (5 vols). The last was in 1832 (8 vols). Bacon is useful since it bridged the historical period from Blackstone (1765) to Chitty (1820) and it was detailed. It is clear that Chitty used Bacon when compiling his own text.
} 
- $\quad$ Prize \& Booty. It is suggested that the law on this (which only applies in war time) is wholly out of date and should be abolished. It may be noted that British civilian subjects ('private persons') had no right to take prize or booty (i.e. to plunder); ${ }^{29}$

- $\quad$ Armed Forces Wills. Any material on this should be in a Wills Act;

- Greenwich \& Chelsea Hospitals. This material does not need to be in primary legislation. It would be more useful for it to be in a SI, enabling easier amendment. So too, material relating to the Imperial War Museum and to War Graves;

- $\quad$ Court Martial Appeals. It is suggested the Court Martial (Appeal) Court be abolished and merged into the Court of Appeal;

- $\quad$ Others. Material on Armed Forces (Housing) Loans, the Registration of Births, Deaths and Marriages, Services Complaints, Protection of Military Remains - and, possibly, some of the other Acts mentioned - do not need to be in primary legislation. It would be more useful for such to be in a SI, enabling easier amendment.

In conclusion, there should be an Armed Forces Code (or Act) consolidating armed forces legislation.

\section{MILITARY CROWN PREROGATIVES PREVIOUSLY DISCUSSED}

In the context of a Crown Act and a Government Act, the following Crown prerogatives were discussed:

- $\quad$ Sovereign as Commander-in-Chief (' $\mathbf{C}$-in- $\mathbf{C}$ '). Historically, the sovereign was $\mathbf{C}$-in-C since the same was responsible for leading his troops into battle. This did not occur with Queen Mary (1553-8) or Elizabeth I (15581603). The last sovereign to lead his troops into battle was George II in 1743 and the role of the sovereign as an active (i.e. an executive) $\mathrm{C}$-in-C ended in $1793 .{ }^{30}$ Thus, any Crown prerogative for the sovereign to act other than as a titular (ceremonial) $\mathrm{C}$-in-C should be abolished. Also, no member of the royal family should hold any ceremonial title in the armed forces. In short, a Crown Act (or Armed Forces Act) should state that:

(1) The sovereign is, ex officio, titular commander-in-chief of the Armed Forces.

(2) Apart from (1), no person shall hold a ceremonial rank in the Armed Forces, including any member of the

$$
\text { Royal Family. }{ }^{31}
$$

Such will complete the ending of military sinecures, a process initiated by Queen Victoria in 1871. She abolished the purchasing of army ranks, by means of a royal warrant (issued under the sign manual); ${ }^{32}$

- Embargo and Blockade. There is a Crown prerogative to impose an:

- embargo; ${ }^{33}$ or

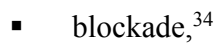

on civilian shipping in war time (but not during peace time). ${ }^{35}$ Today, in the (unlikely) ${ }^{36}$ event of such being employed, it would seem wholly appropriate that any embargo (or blockade) of civilian shipping (whether in peace or war time) only be effected with the consent (resolution) of Parliament. ${ }^{37}$ And, that any Crown prerogative applicable be abolished. ${ }^{38}$ In any case, war time legislation would (likely) cover such an eventuality (in WW1 and WW2 extensive war time legislation was passed);

\footnotetext{
${ }^{29}$ W Forsyth, Cases and Opinions on Constitutional Law (1869), p 479 (possible legal opinion of Sir James Marriott) c. 1764-98 'no private person hath power to make devastations [that is, to destroy enemy property, real and personal] in an enemy's country, or to carry off spoil or plunder [i.e. booty] without permission from his sovereign.'

${ }^{30}$ Maitland, n 9, pp 454 'What led to the appointment of a [professional C-in-C] was, it seems, the use for political ends of the king's power of appointing and dismissing officers.'

${ }^{31}$ See McBain, $\mathrm{n} 1$ (Crown Act), p 73 (with slight amendment of wording).

${ }^{32}$ See S Amos, Fifty Years of the English Constitution 1830-1880 (1880), pp 28-31. Also, AB Keith, The King and the Imperial Crown (1936), vol 2, pp $71 \& 308$.

${ }^{33} \mathrm{~F}$ Stroud, The Judicial Dictionary ( $2^{\text {nd }}$ ed, 1903) (embargo) 'An embargo is an arrest laid on ships or merchandise by public authority, or an order prohibiting ships from putting to sea, and sometimes from entering ports'.

${ }^{34}$ Ibid, (blockade) 'A blockade may be more or less rigorous, either, (1) for the single purpose of watching the military operations of the enemy and preventing the egress of their fleet; or (2) to cut off all access of neutral vessels to the interdicted place: the latter is strictly and properly a blockade; for the other is, in truth, no blockade at all as far as neutrals are concerned.' Quoting Lord Stowell in The Juffrow Maria (1800) 3 Rob C 154, 156. See also Halsbury, Laws, n 6, (5 ${ }^{\text {th }}$ ed), vol 20, para 551.

${ }^{35}$ As Halsbury, Laws ( $5^{\text {th }}$ ed), n 6, vol 20, para 549 notes, embargos are illegal in peace time. Also, 'In anticipation of the outbreak of war in 1939 the Crown's prerogative powers were augmented by wide powers to make defence regulations by [OIC], and those powers were used to control the departure of shipping... from the country.'

36 'Unlikely' because of the nature of modern warfare with submarines, aircraft etc. Also, civilian ships (generally) keep well away from warring countries - due to insurance issues, a risk of breaching sanctions etc.

${ }^{37}$ Doing so in the case of neutral civilian ships would be a charged political matter. In the case of enemy civil ships, such would (for obvious reasons) be unlikely to enter UK ports during war time.

${ }^{38}$ See McBain, n 1 (Crown Act), p 73.
} 
- $\quad$ Requisitioning of British (or British Territory) Civilian Ships. There is an existing Crown prerogative, of unclear purport, to be able to requisition British civilian ships in the case of an emergency (especially, during war time). ${ }^{39}$ Such is rare (not least, since armed forces and police vessels may be utilised). The payment of (reasonable) compensation would seem requisite. Today, it would, also, seem appropriate that any requisition (that is, compulsory acquisition) only be effected with the consent of Parliament, whether in peace time or war time. And, that any Crown prerogative relating to same be abolished; 40

- Compulsory Acquisition (Requisition) of Real Property. The Crown asserted that it had a prerogative to compulsory acquire land during war time (or other great emergency). This became rare since the UK was never invaded by foreign powers and the only great threat of this was by the Spanish Armada (in 1558) in the time of Elizabeth I (1558-1603), a threat which never eventuated. From Victorian times, legislation provided for the compulsory requisition of land by legislation, with compensation payable. ${ }^{41}$ In the case of WW1 and WW2, legislation so provided. Thus, any Crown prerogative to compulsorily acquire (that is, to requisition) land, whether in war or peace time, should be abolished.

In conclusion, the above should be set out in a Crown Act - or in an Armed Forces Act - with the relevant Crown prerogatives being abolished.

Also discussed in the article on the Crown Act, were a number of military Crown prerogatives which it was asserted were obsolete, viz. any Crown prerogative to:

(a) billet any member of the armed forces on the general public; ${ }^{42}$

(b) impose martial law (including the jurisdiction of courts martial) on civilians, ${ }^{43}$

(c) impress civilian subjects for military service (see also 15); ${ }^{44}$

(d) issue letters of marque and reprisal; ${ }^{45}$

(e) dig for saltpetre (for gunpowder); ${ }^{46}$

(f) enter private land to dig for saltpetre;

(g) castellate (that is, to build a castle or fortified residence), ${ }^{47}$

(h) erect military fortifications on private land; ${ }^{48}$

\footnotetext{
${ }^{39}$ Halsbury, Laws ( $5^{\text {th }}$ ed), n 6, vol 20, para 547 'The Crown has a prerogative right in a national emergency to requisition British ships in territorial waters.' Such may also apply to British ships on the high seas and in foreign ports. Ibid. See also McBain, n 1 (Crown Act), p 73. The position as to its application to British Territories (i.e. the Channel Islands and BOT) is uncertain. However, since the UK is responsible for their defence, reference to them would seem appropriate.

${ }^{40}$ See McBain, n 1 (Crown Act), pp 45 \& 74.

${ }^{41}$ In the case of the acquisition of land by the military see various Military Lands Acts, see Appendix $\boldsymbol{A}$ hereto. Also, Halsbury, Statutes $\left(4^{\text {th }}\right.$ ed), vol 3 (2021 reissue)

${ }^{42}$ This was replaced by legislation and could not include the air force in any case. It was hugely resented. It also became unnecessary when permanent army barracks were built in the $19^{\text {th }}$ century. Halsbury $\left(5^{\text {th }} \mathrm{ed}\right), \mathrm{n} 6$, vol 20, para $560^{\text {' }}$ The term 'billeting' is no longer in statutory use, and any requirement for the accommodation of members of the armed forces may now be made under emergency regulations under the Civil Contingencies Act 2004'. See also Maitland (in 1887-8), n 9, p 452.

${ }^{43}$ Martial law (or the law martial) was an older term for military law. However, after 1688, when military law became laid down in legislation it's secondary meaning - that of applying military law to civilians - prevailed. This Crown prerogative was never exercised post-1627 in England, see GS McBain, Abolishing Obsolete Crown Prerogatives relating to Martial Law, Conscription and Billeting [2012] International Law Research, vol 1, no 1, pp 13-52. Its application in colonies was fairly disastrous, Ibid, p 35 et seq. See also Anson, n 14 vol 2, pt 1, pp 315-8.

${ }^{44}$ This applied (in practice) only to the conscription of able-bodied civilian seamen aged 18-55 for the navy (after 1740, the age limit was 18 45, see Maitland, $n 9, p$ 462). Whether there was a Crown prerogative to conscript (i.e. forcibly impose service) in the army is dubious, see 15. In WW1 and WW2 legislation was used to provide for compulsory military service. Chalmers (in 1936), n 11, p 205 'impressment [for the navy] being now obsolete, though never formally abolished.'

${ }^{45}$ This ended when privateering ended in 1856 (Declaration of Paris respecting Maritime Law, to which the UK was a party). As Chalmers (in 1922), n 11, p 107 put it: 'Letters of marquee [also, called letters of marque and reprisal] were...granted by the king in the old days, but this practice of privateering is not adopted now, as England abandoned the practice by entering into an international convention.'

${ }^{46}$ This was obsolete by the $19^{\text {th }}$ century at the latest with the development of chemical methods to make gunpowder.

${ }^{47}$ Castellation was obsolete by the end of the medieval ages. See also GS McBain, Expanding Democracy - Transferring the Crown Prerogative to Parliament (2014) Review of European Studies (2014), vol 6, no 1, pp 34-5.

${ }^{48}$ This is not the same as castellation, supra - which was when private landowners fortified their homes (by turning them into castles for military purposes). Nor the same as the compulsory acquisition (i.e. requisition) of land by the military, although it was similar. This was an older Crown prerogative enabling, in the time of emergency, the Crown (as well as British subjects) to erect fortifications (bulwarks) on another's land when invasion was threatened - or, possibly, when sea walls failed. See Chitty, n 7, p 49 'in case of necessity, the king may enter on the lands of his subjects to make fortifications.' Also, Saltpetre's Case (1606) 12 Co Rep at p 12 and Chalmers (in 1922), n 11, pp 111-2. See also Halsbury, Laws, n 6, ( th $\left.^{\text {ed }}\right)$, vol 20, para 546 'In time of war the Crown may enter on a person's land, for example to erect fortifications. but in... the 1914-18 and 1939-45 wars special powers were conferred by statute and regulations to take necessary action with regard to the requisition of property, the entry on land and many other national needs, and the wide scope of those powers rendered unnecessary recourse to the royal prerogative...' Ibid, para 552 'statutory powers for the compulsory acquisition of land and the stopping up of footpaths,
} 
(i) impose a toll for murage (in order to build city or town defensive walls); ${ }^{49}$

(j) take prize ${ }^{50}$ or booty. ${ }^{51}$

Some of these have been previously discussed in the context of a Crown $A c t^{52}$ and they are not dealt with here (though, their abolition could be placed in an Armed Forces Act or Code as an alternative to a Crown Act). Further, there are other Crown prerogatives sometimes mentioned in the military context (because they concerned the borders of the realm) which have, also, been discussed in the context of a Crown Act viz. any Crown prerogative to:

(k) issue a letter of safe conduct (the precursor to the passport); ${ }^{53}$

(1) prohibit a subject from leaving the realm (including by means of the writ ne exeat regno) $;{ }^{54}$

(m) order a subject to return to the realm. ${ }^{55}$

It has been asserted these Crown prerogatives are obsolete. These have been previously discussed in the context of a Crown Act and - in the case of passports - in the context of a BTFRA and they are not dealt with here although, their abolition could, also, be placed in an Armed Forces Act (Code).

In conclusion, all the above should be set out in a Crown Act (or an Armed Forces Act) with the relevant Crown prerogatives being abolished.

\section{MILITARY STRUCTURE}

As noted in articles on Quangos $^{56}$ - and on Government ${ }^{57}$ - the MOD needs a corporate structure. One which could incorporate many quangos relating to the military. Thus, it was suggested that it needed an Armed Forces Command Board, with various divisions. This will not be discussed further.

\section{MILITARY CROWN PREROGATIVES NOT YET DEALT WITH}

Instead, this Article considers various military Crown prerogatives not previously dealt with. These comprise Crown prerogatives to:

- $\quad$ make (i.e. wage) war;

- declare war;

- make peace;

- declare peace.

From the prerogative to make war derives the following sub-prerogatives. Crown prerogatives in respect of:

- the management, and operation, of the UK's armed forces (also, the territorial army);

- the management, and operation, of the UK's military installations;

- exporting UK military equipment in war time; $\quad$ (obs, replaced by legislation)

- trading with the enemy in war time; $\quad$ (obs, replaced by legislation)

- conscripting British subjects for the army; $\quad$ (obs, replaced by legislation)

- $\quad$ angary (i.e. the requisition of neutrals' property during war time). ${ }^{58}$

which may be exercised by the [SS] for Defence for the service of his department or the defence of the realm.' In any case, there is no need for subjects to have such a right today, whether in the case of war or emergency. See also McBain, n 47, pp 36-8.

${ }^{49}$ This was obsolete by the end of the medieval ages.

${ }^{50}$ Stroud ( $2^{\text {nd }}$ ed, 1903) (prize), n 33, 'A prize of war, as distinguished from booty, is a belligerent capture [i.e. during war] of an enemy's ship or other property at sea.'

${ }^{51}$ Booty is prize but on land. Stroud ( $2^{\text {nd }}$ ed, 1903) (booty), n 33 'Booty consists in whatever can be seized upon land by a belligerent force irrespectively of its own requirements, and simply because the object seized is the property of the enemy. In common use, the word is applied to arms and munitions in possession of an enemy force, which are confiscable as booty although they may be private property' but rightly, the term includes also all property which is susceptible of appropriation.'

${ }^{52}$ See McBain, n 1 (Crown Act), p 73.

${ }^{53}$ Letters of safe conduct were supplanted by passports by Victorian times. See also McBain, n 3, (BTFRA), Pt 1. Also, GS McBain, Abolishing Obsolete Crown Prerogatives relating to the Military (2011) Nottingham LJ, pp 23-6. For an early example of a safe conduct see HWC Davis, Regesta Regum Anglo-Normannorum 1066-1154 (1913), p 78 (1088).

${ }^{54}$ In abeyance, pre-1688. The reference is to a State writ, not to a writ between private parties in an equity suit, see McBain, $\mathrm{n} 1$ (Crown Act), p 86. See also Halsbury ( $5^{\text {th }}$ ed), n 6, vol 20, para 549. Also, McBain, n 53, pp 26-33.

${ }^{55}$ In abeyance, pre-1688. See McBain, n 1 (Crown Act), p 86. See also Halsbury ( $5^{\text {th }}$ ed), n 6, vol 20, para 549 and McBain, n 53, pp 33-5.

${ }^{56}$ See McBain, n 1 (Quangos), pp 41-3.

${ }^{57}$ Ibid, (Government Act), n 1, pp 89, 111-2.

${ }^{58}$ See Halsbury, Laws $\left(5^{\text {th }}\right.$ ed), n 6, vol 20, para 547, n 1. 
As will be seen, this article asserts that all the above (where not obsolete) should be inserted in legislation. And, that the relevant common law Crown prerogative be abolished, since the latter is out of date and not fit for purpose.

In conclusion, all military Crown prerogatives should be abolished and those still required, placed in legislation.

\section{CROWN PREROGATIVE - MAKING WAR}

Since Anglo-Saxon times the sovereign has had the prerogative to make war. ${ }^{59}$ This is unsurprising since, among the Anglo-Saxons (like their German forebears), early kings were (usually) chosen for their martial prowess and they led their troops into battle. ${ }^{60}$ This did not change under the Anglo-Normans. Indeed, William I (1066-87) acquired England by conquest, as well as via his assertion that he was the legitimate successor of Edward the Confessor (1042-66) to the Crown.

\section{(a) Historical Background}

A previous article has dealt with this in detail. ${ }^{61}$ As noted therein, it has long been the legal proposition that the sovereign alone has the prerogative (the right) to wage war. Thus, Smith (writing 1562-5) stated:

The monarch...has absolutely in his power the authority of war and peace, to defy what prince it shall please him, and to bid him war, and again to reconcile himself and enter into league [i.e. a peace treaty] or truce with him at his pleasure or the advice only of his privy council (spelling modernized) ${ }^{62}$

Blackstone (writing in 1765) stated:

Upon the same principle [as that of making treaties] the king has also the sole prerogative of making war and peace. For it is held by all the writers on the law of nature and nations, that the right of making war, which by nature subsisted in every individual, is given up by all private persons that enter into society, and is vested in the sovereign power: and this right is given up not only by individuals, but even by the intire [entire] body of people, that are under the dominion of a sovereign. It would indeed be extremely improper, that any number of subjects should have the power of binding the supreme magistrate [i.e. the sovereign], and putting him against his will in a state of war. ${ }^{63}$

Chitty (in 1820) stated:

As representative of his people, and executive magistrate, the king possesses...the exclusive right to make war or peace, either within or out of his dominions; and the constitution leaves it to the king's discretion to grant or refuse a capitulation or truce to an enemy. ${ }^{64}$

Wade (in 1931) stated:

The king is the sole representative of the nation in international dealings; it is his prerogative...to make war and peace...65

Chalmers (in 1936) stated:

As representative of his people and as executive magistrate the king possesses the exclusive right to make war or peace, and the law of the constitution leaves it to the king's discretion to grant or refuse a capitulation or truce to an enemy. ${ }^{66}$

Moreover, until 1688, there was no other person or body with the authority (or the capacity) to raise and control the armed forces. ${ }^{67}$ In 1688, a limitation was imposed on the sovereign with the Bill of Rights 1688 providing (and it still does) that:

\footnotetext{
${ }^{59}$ FCT Tudsbery, Prerogative in Time of War (1916) 32 LQR 384 'The defence of the realm has by our constitution been entrusted to the Crown, and from the time of the Norman Conquest onwards the military forces of the [UK] have always been maintained by the Crown as the authority responsible for the defence of the kingdom.' See also GS McBain, n 53, pp 16-7 and McBain, n 47, pp 19-31.

${ }^{60}$ The last English king to do so was George II (1727-60) who fought at Dettingen in 1743. In 1793, the sovereign gave up personal command of the armed forces when a commander in chief was appointed. See McBain, n 53, p 17, n 29. Also, AB Keith, The Constitution of England from Queen Victoria to George VI (1940), vol 2, p 164 'In 1793 the king surrendered command-in-chief to the General Commanding-inChief...'.

${ }^{61}$ McBain, n 47, pp 19-31.

${ }^{62}$ T Smith, De Republica Anglorum (trans. Dewar, CUP, 2009), p 85. See also Coke (work published 1641), n 25, vol 3, p 9 'no subject can levy war within the realm without authority from the king, for to him it only belongeth.'

${ }^{63}$ Blackstone, $\mathrm{n} 27$, vol 1, p 249. See also Bacon, n 28, vol 5, p 532 'The power of making war or peace inter jura summi imperii and is lodged singly in the king; though, as my Lord Hale says, it ever succeeds best when done by parliamentary.' The reference is to M Hale (C-J), History of Pleas of the Crown (1736), vol 1, p 130. See also McBain, n 53, pp 19-20 and McBain, n 47, pp 19-31.

${ }^{64}$ Chitty, n 7, p 43. Ibid, p 6 ' $[\mathrm{HM}]$ alone can legally... declare war and peace. As depository of the strength of his subjects, and as manager of their wars, the king is generalissimo of all land and naval forces: $[\mathrm{HM}]$ alone can levy troops, equip fleets, and build fortresses.'

${ }^{65}$ Wade, $n 12, \mathrm{p} 67$. However, he accepted that the control of the armed forces was, $\mathrm{p} 326$, 'exercised through civilian cabinet ministers at the head of government departments, composed partly of service members and partly of civilians...The king is, however, technically the [C-inC] of all the forces of the Crown.'

${ }^{66}$ Chalmers (in 1936), n 11, p 160.

${ }^{67}$ That said, it was not until 1793 that the sovereign relinquished his post as executive C-in-C, see ns $30 \& 60$.
} 
The raising and keeping a standing army ${ }^{68}$ within this kingdom in time of peace unless it is with the consent of Parliament is against [the] law. (italics supplied)

This section was specifically designed to preclude the sovereign (at that time, James II (1685-8) from keeping a standing army without Parliamentary consent. ${ }^{69}$ However, obviously, if legislation (a Crown Act) makes it clear that the sovereign has no executive role in relation to the armed forces (especially, the army) this section is no longer required. The Settlement Act 1700, s 3 (still extant) also provided:

That in case the crown and imperial dignity of this realm shall hereafter come to any person not being a native of this kingdom of England, this nation shall not be obliged to engage in any war for the defence of any dominions or territories which do not belong to the crown of England, without consent of Parliament. ${ }^{70}$ (italics supplied)

Similarly, if legislation (a Crown Act) makes it clear that the sovereign has no executive role in relation to the armed forces (especially, the army) this s 3 is no longer required.

\section{(b) Making War: Post-1688}

After 1688, the role of the sovereign in the making of war diminished and it (effectively) ended by 1743 when the sovereign no longer went into battle with his troops. Instead, the decision to make war was one in which the sovereign took the advice of his ministers in cabinet. And, the control - and administration - of the armed forces became the task of the Ministry of Defence (the 'MOD') (albeit, there were many name changes prior to this description being chosen for the relevant ministry). ${ }^{71}$ Thus, Anson (in 1935) stated:

The king, acting on the advice of his ministers, makes war and peace..$^{72}$

There was, also, increasing involvement of Parliament in the process. Keith (in 1940) stated:

The right to make war and peace and declare neutrality is vested in the Crown as part of the prerogative...The assent of the Commons to the making of war is demanded by constitutional usage; its support was awaited in 1914, though steps had been taken in preparation to have naval and military forces ready for defence. In like manner in 1938 the mobilisation of the fleet was ordered in the crisis before it was known whether war could be avoided. It is however, noteworthy that in that case a guarantee to Czechoslovakia of her remaining territories by the [PM] before consulting the House of Commons, which was compelled to homologate [ratify] it or to repudiate his leadership. ${ }^{73}$

Halsbury (in 2014) stated:

War can be commenced or terminated only by the authority of the Crown. ${ }^{74}$

Barnett (in 2020) stated:

The sovereign is $\left[\mathrm{C}\right.$-in-C] of the armed forces ${ }^{75} \ldots$ [However] The $[\mathrm{PM}]$, acting in the name of the Crown, has hitherto had the ultimate say in committing troops to British troops to military action. For example in $1939 \ldots$ when German troops invaded Poland on 1 September, the British [PM] declared that Britain was at war with Germany. More recently, in 2003 the British [PM] backed the United States' invasion of Iraq by committing British troops, without prior parliamentary approval. In practical terms, the deployment of troops cannot be effected without Parliament's approval of finance - accordingly parliament must (albeit belatedly) approve the government's decision. ${ }^{76}$

The latter statement reflects the reality of the situation. It is the government and, more particularly, the cabinet which decides on war. This is appropriate since there is little point to waging war if the MOD and the armed forces do not actually have the capacity to undertake such. ${ }^{77}$ Further, the MOD (in any case) is responsible for the control and deployment of the military in practice, since modern warfare requires a huge amount of planning, logistics and supply (more so than in the past). Thus, waging war, today, is very much a political and a practical matter and

\footnotetext{
${ }^{68}$ This provision was not designed to deal with the navy (and was prior to the development of an air force). Wade, $\mathrm{n} 12, \mathrm{p} 318$ 'This provision was not due so much to the objection to military service as to the realisation that the army might be dangerous to the liberty of the subject in the hands of an unwise ruler.'

${ }^{69}$ See also OH Phillips \& P Jackson, Constitutional and Administrative Law ( $8^{\text {th }}$ ed, 2001), p 386 'Before the revolution of 1688 the legal authority for raising and maintaining an army and navy was the royal prerogative. To ensure Parliamentary control over the army the Bill of Rights 1688 provided that 'The raising and keeping a standing army within this kingdom in time of peace unless it is with the consent of Parliament is against law.' Also, Munro, n 20, p 266 'abolition of one...prerogative power, that of keeping a standing army in peace time without parliamentary consent.'

${ }^{70}$ See also Blackstone, n 27, vol 1, p 106.

${ }^{71}$ See also $\mathbf{1 0 ( b )}$.

${ }^{72}$ Anson, n 14, vol 2, pt 2, p 136.

${ }^{73}$ Keith, n 60, vol 2, p 128.

${ }^{74}$ Halsbury, Laws, n 6, (5 $5^{\text {th }}$ ed), vol 20, para 544.

${ }^{75}$ This is only technically true. The role of the sovereign is only a formal one today.

${ }^{76}$ Barnett, n 23, p 109.

${ }^{77}$ If one considers English domestic wars from the Norman Conquest (1066), most were lost because the sovereign decided on war without adequate preparation. That is, his advisers encouraging him to war when they had no knowledge (or experience) of the military need for logistical support, supply lines, back up, good communications etc. The Stuarts were particularly prone to this.
} 
the sovereign is no longer involved. More especially, in a democratic society, it is essential that Parliament be involved. Not just because it is footing the bill, but because waging war is a political decision of the highest order. Thus, at some stage, the consent of Parliament is essential.

\section{(c) International Armed Intervention - Not War}

Another issue must be taken into account when considering the legal nature of waging war. Since WW2 (1939$45)$ the UK has been involved in many armed inventions without the same comprising the making of war as such. Thus Barnett (in 2020) noted:

Interventions by armed forces in another sovereign state may involve either the use of military force or humanitarian aid. Interventions have to be seen within the context of the UK's membership of both the [UN] and [NATO]. Since the 1990s, UK armed forces have been involved in military interventions including Bosnia (1992), Kosovo (1999), Sierra Leone (2000), Afghanistan (2001), Iraq (2003), Libya (2011) and Mali (2012). The wide-reaching power relating to the deployment of troops, exercised without Parliament's prior consent, is controversial. The Constitutional Reform and Governance Bill 2009-2010 provided that in relation to war, international armed conflict and international peace-keeping activities, prior approval must be given by each House, by resolution, except when the $[\mathrm{PM}]$ considers that exceptional considerations require immediate action. The provision, however, did not survive the passage of the Bill and accordingly the prerogative power relating to the deployment of troops remained in the hands of the government. It is, however, accepted there now exists a constitutional convention that Parliament should have the opportunity to debate the issue, and that Parliament's decision binds the government.

In 2011 the Foreign Secretary committed the government to 'enshrine in law for the future the necessity of consulting Parliament on military action'. On 29 August 2013 the government was defeated on a proposal to authorise the use of military force in response to the situation in Syria and the use by the Syrian government of chemical weapons. Following the vote (322 to 220), the [PM] stated that: 'It is very clear tonight that...the British Parliament, reflecting the views of the British people, does not want to see military action. I get that, and the Government will act accordingly. ${ }^{78}$

In conclusion, these days, war is rarely declared by any country and - in the case of the UK - there have only been limited international military engagements undertaken by the UK, post-WW2. Parliament must be involved in some way, anyway, in respect of these (and of war) since it is the only body which can vote supplies. Further, there appears to have developed a convention that any military action taken by the UK abroad (including peace keeping) requires a prior Parliamentary resolution (approval).

(d) $\underline{\mathrm{HC} \text { Select Committee }}$

Another important matter which Barnett (in 2020) noted was the stance of the House of Commons, through their Select Committee. She stated:

The Political and Constitutional Affairs Select Committee of the $[\mathrm{HC}]$ has published several reports on the role of Parliament in relation to conflict decisions. In its Twelfth Report of 2013-2014, 'Parliament's Role in Conflict Decisions: A Way Forward', the [C-ee] was critical of the lack of progress made by the government on the issue. One difficulty lies with ministerial responsibility: responsibility for constitutional issues lies with the Deputy [PM]. However, decision relating to [the] deployment of troops involves also both the [MOD] and [FCO]. The [C-ee] recommended that one minister should be appointed to take special responsibility for advancing progress.

The two options for reform are, first an Act of Parliament or, second, a parliamentary resolution. In relation to an Act of Parliament the government has several concerns. One is that there are a wide range of situations in which the armed forces might be deployed and these lead to definitional difficulties. A second expressed concern is that an Act of Parliament might run the risk of judicial review. This ' $r i s k$ ', however, is slight in that the courts would regard any question of deployment of troops as non-justiciable. A further concern involved the legal advice given to the government by the $[\mathrm{A}-\mathrm{G}]$ on the legality of military action. By convention that advice is never disclosed. However, it would be difficult for [MP's] to decide an issue if it did not have the benefit of legal advice.

The Select [C-ee] favoured an Act of Parliament but recognising the difficulties, accepted that a resolution might be the best way forward in advance of an Act. The resolution would: 'have the effect of setting out in writing the procedure by which Parliament is consulted on conflict decisions, and creating a strong political expectation that the government would follow this procedure. ${ }^{79}$

\section{(e) Civil Contingencies Act 2004}

Another important issue to take into account is the nature of modern warfare (especially, nuclear war), war may have to be initiated very rapidly, preventing Parliament being able to meet to confirm the decision of cabinet. The

\footnotetext{
${ }^{78}$ Barnett, $\mathrm{n} 23$, pp 109-10. She continued 'Professor Malcolm Chambers if the Royal United Services Institute was to comment that: 'It is now hard to see how any UK Government could undertake significant military action without the support of Parliament, or indeed the wider public.'

${ }^{79}$ Ibid, p 110.
} 
Civil Contingencies Act 2004 deals with national emergencies, This includes 'war' that threatens 'serious damage' to the security of the UK. ${ }^{80}$ In such a case regulations may be made by:

- $\quad$ the privy council (i.e. HM in council); or

- a 'senior minister' who comprises (i) the PM; (ii) any of HM's principal Secretaries of State; or (iii) commissioners of HM's treasury. ${ }^{81}$

The Act of 2004 is now somewhat dated, in that it is now nearly 20 years old and there have been huge advances in warfare. For example, missiles can wipe out a country within minutes and there may be no advance declaration from an enemy country. Then, there is electronic warfare which can achieve much the same effect and paralyse government and military computer systems within minutes (seconds). Further, the privy council referred to above is (and has long been only a formal body). The real decisions are taken by cabinet and other ministries with the privy council simply rubber-stamping them (which is why a prior article has suggested the abolition of the privy council).

Thus, in any case it is suggested that the 2004 Act be amended, to provide for regulations being made by: (a) the cabinet; or (b) the PM and certain designated ministers - such as the MOD minister and the FCDO minister. Finally, it should be indicated that they come into effect immediately (this being an emergency) but that, for their continuance, they must be laid before Parliament within (say) 7 days. And, that they are nullified if the latter so resolves.

\section{(f) Current Position - A Recipe for Disaster?}

One of the great disasters in UK past history was the Crimean War (1855). Much of the problem was due to the lack of a clear 'chain of command' and a lack of accountability. WWI also provides various examples of huge loss of British life through poor decision-making, lack of adequate communications, service rivalry etc. Looking at the present law cited above in relation to 'war' and ' $U K$ involvement in armed conflict abroad', one can see great potential for disaster in the future. Why? The present chain of command (in legal terms) is completely opaque. In particular, one would suggest the following changes:

- $\quad$ Sovereign. The same is now only a titular $\mathrm{C}$-in-C and this should be made clear in legislation. Further, it would seem advisable to excise any remaining military sinecures (such as those relating to the royal family);

- $\quad$ Crown Prerogatives. All of these in relation to: (a) war; and (b) to armed intervention abroad (including peace keeping) are opaque. All Crown prerogatives relating to the military should be abolished and things set out clearly (and intelligibly) in legislation.

- $\quad$ Distinction. Legislation should clearly distinguish between: (a) war; and (b) armed intervention abroad in peace time (including peacekeeping) which is not war. The first has a different level of gravity. In the case of (b), a resolution of Parliament should not just be a convention, but a statutory pre-requisite. ${ }^{82}$ Further, there is long established precedent, the Confirmation of the Charters 1297 (still extant) provides that the Crown cannot raise money by way of any tax ('tasks') or aid (i.e. a request for a voluntary donation which is actually a demand) to finance the business of war without the consent of Parliament (see 15)..$^{83}$

- Chain of Command. In WW1, after much trial and error, it was seen that - in the case of war - a War Cabinet comprising a small number of people worked, since it enabled urgent decisions to be reached quickly. ${ }^{84}$ Further, since WW2, the MOD ${ }^{85}$ is in overall charge of the control, supply and operation of the Armed Forces. This should

\footnotetext{
${ }^{80}$ Civil Contingencies Act 2004, ss 1 \& 19 (definition of emergency).

${ }^{81}$ There is no provision for the sovereign to declare war in person or to issue a proclamation.

${ }^{82}$ See the observation of RFV Heuston, Essays in Constitutional Law (1964), p 65 'action may be taken under the prerogative without the necessity of that prior parliamentary approval which the promotion of a statute requires. If the conduct of foreign affairs and the disposition of the armed forces of the Crown had not been included within the prerogative, the cabinet might have hesitated in 1956 before embarking on the Suez adventure.' However, the Suez adventure (disaster) is a good reason to argue for a parliamentary resolution.

${ }^{83}$ See Confirmation of the Charters 1297 c 6 'for no business from henceforth we shall take such manner of aids, tasks, nor prises, but by the common assent of the realm, and for the common profit thereof, saving the ancient aids and prises due and accustomed.' 'Tasks' was the Anglo-Norman word for 'tax'. See generally, GS McBain, Modernising the Monarchy in Legal Terms (2010) King's Law Journal, vol 21(3), p 544 .

${ }^{84}$ LS Amery, Thoughts on the Constitution (1964), p 79 'The War Cabinet of 1916 consisted of five members...This freedom from routine enabled the cabinet to meet every morning for five days of the week and oftener without disorganising the work of departmental ministers who only attended when their own particular business was affected. It afforded much more time for the discussion and thinking out of policy among members of the war cabinet...Besides ministers directly affected their expert advisers and, more particularly, the Chiefs of Staff habitually attended...Members of the War Cabinet presided over all important ministerial committees...Their higher authority and the time at their disposal enabled them to play a dominating part both in shaping the conclusions of such committees and in securing their acceptance by the cabinet. The decisions where those of the cabinet and not compromises between conflicting departmental views.'

${ }^{85}$ The modern MOD and Minister of Defence is really post WW2, see Amery, n 84, p 84 who noted 'The appointment in 1936 of a minister to coordinate defence at large with no department of his own served little purpose. Full value was only secured from the Chiefs of Staff Committee when [Churchill] became his own Minister of Defence and the Chiefs of Staff became in effect his direct subordinates. In this way the Chiefs of Staff Committee, assisted by Joint Intelligence and Planning Staffs set up in the Cabinet Offices, provided a much better instrument for dealing with strategical problems than [Lloyd George] had at his disposal in [WW1]...'.
} 
also be recognised. Legislation should recognise this since the ministry with such responsibilities is the only one that can actually deliver the support to ensure military success;

- $\quad$ Emergencies. The Civil Contingencies Act 2004 (usefully) deals with emergency. However, war is of the greatest emergency. Thus, it would seem useful for any provisions to be dealt with very clearly in modern legislation, taking into account things such as nuclear war, ${ }^{86}$ a first strike without warning etc.

\section{(g) Conclusion}

The Crown prerogative as to the making of war was (likely) the first, most basic - and most important - of all Crown prerogatives in Anglo-Saxon times. Today, for obvious reasons, it is vital that it be up-to-date and clear.

War. Hence, the Crown prerogative to make war should be abolished since the 'Crown' - as such - is no longer involved.$^{87}$ Instead, the decision is an executive one, taken by the cabinet. An executive decision which should require a prior resolution of Parliament - save where there is an absolute emergency. Given the nature of modern warfare (especially, nuclear war), war may have to be initiated very rapidly, preventing Parliament from being able to meet to confirm the decision of cabinet. Thus, provision should also be (tailor) made in legislation for war to be waged without a prior resolution of Parliament in the case of absolute emergency. ${ }^{88}$

Armed Intervention Abroad. In the case of armed intervention abroad by the UK, in modern times, this is likely to be in the form of peacekeeping (or a military intervention) in the company of long time allies (or NATO or UN forces) ${ }^{89}$ As a result, there is more time to enable the prior consent of Parliament - and Parliament can (these days) meet quickly to pass a resolution. Thus, any modern convention on this should be put in legislation - to clarify the position.

In conclusion, any Crown prerogative to wage war should be abolished and the matter set out in legislation. So too, in respect of any armed intervention abroad (including peace keeping).

\section{CROWN PREROGATIVE - DECLARATION OF WAR}

(a) Background

As noted in a prior article, ${ }^{90}$ war did not have to be declared, prior to being initiated. However, an international convention grew up (mainly fostered by legal writers) that a formal declaration of war should be made. Blackstone (in 1765) stated:

And the reason which is given by Grotius, ${ }^{91}$ why according to the law of nations a denunciation of war ought always to precede the actual commencement of hostilities, is not so much that the enemy may be put upon his guard, (which is a matter rather of magnanimity than right) but it may be certainly clear that the war is not undertaken by private persons, but by the will of the whole community; whose right of willing is in this case transferred to the supreme magistrate by the fundamental laws of society. So that, in order to make a war completely effectual, it is necessary with us in England that it be publicly declared and duly proclaimed by the king's authority; and, then, all parts of both the contending nations, from the highest to the lowest, are bound by it. ${ }^{92}$

However, Chitty (in 1820) stated:

The reason which is given by Grotius why, according to the law of nations, a formal denunciation [i.e. declaration] of war ought always to proceed the actual commencement of hostilities, is, not so much that the enemy may be put upon his guard (which is a matter of magnanimity than right), but that it may be clear that the war is undertaken not by private persons, but the will of the whole community, which, as we have already seen, is in legal contemplation, transferred to and vested in the king. Blackstone argues, from this reason assigned by Grotius, that in order to make a war completely effectual, it is necessary by the law of this country, that it be publicly declared, and duly proclaimed by the king's authority, and then all parts of both the contending nations, from the highest to the lowest, are bound by it. Notwithstanding this, it seems that no public declaration, or formal proclamation of war is, by law, absolutely necessary to render it the duty of the king's subjects to consider and

\footnotetext{
${ }^{86}$ The issue whether the PM should have (like the US President) a nuclear button should be considered since it is unlikely that various countries hostile to the UK will observe past conventions as to the need for a formal declaration of war etc.

${ }^{87}$ For commentary on the influence of Victoria (1837-1901), Edward VII (1901-10) and George V (1910-36) over defence issues in their time, see Keith, n 32, (in 1936), ch 11.

${ }^{88}$ For example, given modern warfare one would well see the possibility of an attempt to kill the PM and other members of cabinet as well as a strike on Parliament. If Parliament is destroyed or incapable of meeting, it is obvious that someone must take the decision without the same. So too, in the case of the destruction of the cabinet.

${ }^{89}$ De Smith (in 1998), n 19, p 155 'the age of military intervention is not over, though one can optimistically assume that nowadays intervention will seldom take place except at the request or with the concurrence of the government of the territory or country concerned or as part of a [UN] or other international force.'

${ }^{90}$ See McBain, n 47, p 28. For example, the war between Spain and England in 1588 (Spanish Armada) did not begin with any formal declaration. Ibid, p 28, n 215. See also Hale CJ (writing in the 1640's) 'a state of war may be between two kingdoms without any proclamation or indication thereof or other matters of record to prove it.' See Bacon, n 28, vol 5, p 532 referring to Hale.

${ }^{91}$ Blackstone followed Grotius (1583-1645) De Jue Belli ac Pacis (On the Law of War and Peace, 1625), see McBain, n 47, p 28.

${ }^{92}$ Blackstone, n 27, vol 1, pp 249-50.
} 
treat as an enemy, any foreign power against whom war has in point of fact been resolved upon and commenced by $[H M] . .^{93}$ (italics supplied)

Maitland (in 1887-8) agreed with Chitty that no declaration of war was required. He stated:

Stephen (following Blackstone) says that to make a war completely effectual it is necessary that it be publicly declared, and duly proclaimed by the sovereign's authority. I believe that to be misleading, and that neither English law, nor what is called international law, requires any formal declaration of war. I believe than an English court would hold that there was war as soon as the queen had authorised acts of hostility. ${ }^{94}$

Halsbury, Laws (1909) stated:

In order to constitute a legal state of war between this country and a foreign state there must be either a formal declaration of war by the Crown or hostilities must have been commenced by the authority of the Crown. ${ }^{95}$

This statement of Halsbury in 1909 seems more accurate legally than that of Blackstone, albeit the convention is that war be officially declared by the Crown.

\section{(b) How War was Declared in the Past}

As to how war was declared, this has changed over time and distinction was made in the case of a civil war and a foreign one.

- $\quad$ Civil War. In the case of a civil war, in times past, the sovereign summoned his army and raised his royal standard prior to battle (whether a civil or a foreign war). Further, the courts were closed (symbolising the closure of civil and criminal justice and the application of military law). ${ }^{96}$ Thus, anyone who then opposed it could be killed in battle (and, often, just after it) and such was - under martial law - not treated as murder; 97

- $\quad$ Foreign War. ${ }^{98}$ Hale (writing in the 1640 's) noted that the sovereign could make a foreign war (or peace) by proclamation. ${ }^{99}$

However, in modern times, the declaration of war was made by the PM. For example, in WW2 (1939-45) the declaration of war against Germany on 3 September 1939 was made by Neville Chamberlain. And, against Japan on 8 December 1941, it was made by Winston Churchill. ${ }^{100}$ Keith (in 1940) noted:

It lies with the executive government to make binding pronouncements on certain issues. Thus the courts will accept declarations as to the status of a foreign government and as to the recognition or non-recognition of a government or of [a] state of belligerency. They accept also any declaration as to whether any person is entitled to recognition as a diplomatic agent or a foreign sovereign immune from British jurisdiction...The existence and determination of a war are likewise so declared, though in the absence of any declaration on this or on the other points mentioned, the court might have to act on its own judgment (italics supplied). ${ }^{101}$

De Smith (in 1998) stated:

The dissolution, summoning and prorogation of Parliament are effected by royal proclamations in council; so too are the declaration and termination of a state of war, and the declaration of a statutory state of emergency. ${ }^{102}$

\section{(c) Conclusion}

In the past, declaring war was the act of the sovereign as the commander-in-chief of the armed forces. However, his role finished by 1793 and the act of declaring war became that of the 'Crown' (the sovereign in the body politic) - albeit a declaration was not legally required as such. In the $20^{\text {th }}$ century, any declaration has been in the hands of the cabinet and it is made in Parliament. Today, statutory provision should be made for the same, with

\footnotetext{
${ }^{93}$ Chitty, n 7, p 44.

${ }^{94}$ Maitland, $\mathrm{n} 9, \mathrm{p} 424$. The reference to Stephen is HJ Stephen, New Commentaries on the Laws of England (14 ${ }^{\text {th }}$ ed), vol 2, p 495.

${ }^{95}$ Halsbury, Laws, n 6, (1 $\left.1^{\text {st }} \mathrm{ed}, 1909\right)$, vol 6, p 442. It continued 'Thus, hostilities against a foreign state, though the whole nation joins therein, without the concurrence of the executive do not constitute a legal state of war or a legal breach of the peaceful relations existing between the two countries.'

${ }^{96}$ Mt Cicero, Pro Milone (ed FH Colson, British Classical Press), 'silent enim leges inter arma' ('For laws are silent when arms are raised, and do not expected themselves to be waited for, when he who waits will have to suffer an undeserved penalty before he can exact a merited punishment.'). See also Roman law and the unfettered power of the Roman general to order death, McBain, n 47, p 33, n 251.

${ }^{97}$ Modern 'military law' is not the same as the 'law martial' which latter expression, today, means imposing military courts and punishments on civilians). A previous article has argued that the latter should be abolished. See GS McBain, Abolishing Obsolete Crown Prerogatives relating to Martial Law, Conscription and Billeting (2012) International Law Research, vol 1, no 1, pp 13-62.

${ }^{98}$ Hale (writing in the 1640's) 'when the king by his writ styled summonitio exercitus [summoning the army], hath prefixed the convening of his army, the usual badge whereof is...the setting up of his standard...And is regularly ended when the king by writ proclaimed his peace.' See McBain, n 47, p 27. See also McBain, n 53, pp 16-7.

${ }^{99} \mathrm{Ibid}, \mathrm{p} 28$. See also opinion of law officers in 1855 in Forsyth, n 29, p 477

${ }^{100}$ McBain, n 53, p 16, n 24.

${ }^{101}$ Keith, n 60, pp 128-9.

${ }^{102}$ De Smith (in 1998), n 19, p 160.
} 
the excision of reference to the Crown. Thus, the PM should declare war. A draft Bill prepared for a House of Commons Committee in 2004 provided that:

No declaration of war shall be made on behalf of the [UK] unless that declaration has been approved by resolution of each House of Parliament. ${ }^{103}$

It would seem appropriate that this be contained in modern legislation, save that such should provide that the:

- declaration should be made by the PM in the House of Commons;

- declaration (and the time at which war commenced) should be evidenced in a SI - not in a proclamation - since the Crown is not involved and the declaration is made pursuant to a resolution of Parliament;

- the wording should leave clear that a declaration is not needed in the case of emergency (such as reflected in the Civil Contingencies Act 2004).

As to the latter point, we live in a nuclear age. If a foreign country launches a nuclear attack against the UK and destroys Parliament, there is little point in envisaging the meeting of the same to declare war. And - even if such does not occur - it takes time for Parliament to assemble. Thus, it stands to common sense that no declaration of war is needed in the case of an emergency (including where an unpremeditated attack has been launched). It is obvious that provision must be made for such a scenario - a situation which the House of Commons committee did not really consider.

\section{In conclusion, an Armed Forces Act should make provision on the need - and method - for declaring war. 9. CROWN PREROGATIVE - MAKING \& DECLARING PEACE}

(a) Background

A previous article has considered this in more detail. ${ }^{104}$ Blackstone (writing in 1765) stated:

the king has...the sole prerogative of making war and peace...And, wherever the right resides of beginning a national war, there also must reside the right of ending it, or the power of making peace. ${ }^{105}$

Chitty (in 1820) stated:

As representative of his people, and executive magistrate, the king possesses...the exclusive right to make war or peace, either within or out of his dominions; and the constitution leaves it to the king's discretion to grant or refuse a capitulation or truce to an enemy. ${ }^{106}$

Halsbury, Laws (first edition in 1909) stated:

As war can only be commenced so it can only be terminated by the authority of the Crown, and this is usually effected by a treaty of peace and announced to the nation by proclamation. ${ }^{107}$

Wade (in 1931) stated:

The king is the sole representative of the nation in international dealings; it is his prerogative to...make peace ${ }^{108}$

Halsbury (in 2014) stated:

Termination of war is usually effected by a treaty of peace and announced to the nation by proclamation or [OIC] 1 [i.e. by a SI]. Proclamations and [OIC] of this nature were made after the 1939-45 war, as also after the 1914-18 war. It may be found necessary for the interpretation of documents referring to the duration of the war in various terms to fix one date, irrespective of the state with which peace was concluded. ${ }^{109}$

Also:

It is usual on such occasions to publish notices as to the signing and ratification of the treaty of peace in the London Gazette, and after ratification the fact that peace is established is usually announced by proclamation. ${ }^{110}$

However, it should be noted that peace did not have to be effected by way of a peace treaty as such. ${ }^{11}$

\footnotetext{
${ }^{103}$ House of Commons, Public Administration Select Committee. $4^{\text {th }}$ Report of Session 2003-4. Taming the Prerogative: Strengthening Ministerial Accountability to Parliament. HC 422 (16 March 2004) ('HC').

${ }^{104}$ McBain, n 47, pp 24, 27-31.

${ }^{105}$ Blackstone, n 27, vol 1, pp 249-250.

${ }^{106}$ Chitty, $\mathrm{n} 7, \mathrm{p}$ 43. He also stated 'The general rule is, 'ubi bellum non est pax est' [where there is no war there is peace]; and therefore, though no league or articles of peace subsist between this and a foreign state, such state is not to be considered or treated as inimical until the king has denounced war against it.' See also Bacon, n 28, vol 5, p 532.

${ }^{107}$ Halsbury, Laws, n 6 (1 $1^{\text {st }}$ ed, 1909), p 444. It continued in a fn 'It is usual on such occasions to publish notices as to the signing and ratification of the treaty of peace in the London Gazette, and after ratification the fact that peace is established is usually announced by a proclamation.'

${ }^{108}$ Wade, n 12, p 67.

${ }^{109}$ Halsbury, Laws, n 6 ( $5^{\text {th }}$ ed), vol 20, para 544. In the case of WW1 the Termination of the Present War (Definition) Act 1918 gave the power to declare the date of the termination of the war by means of an [OIC], which occurred. Ibid, fn 6. See also McBain, $\mathrm{n} 47, \mathrm{p} 29$.

${ }^{110}$ Ibid, fn 4.

${ }^{111}$ An agreement with Thailand on 1 January 1946 (Cmd 8140) as an agreement not amounting to a peace treaty. See also Halsbury, Laws, $\mathrm{n}$ $6,\left(5^{\text {th }}\right.$ ed), vol 20 , para 544 , fn 5 (execution of various peace treaties)
} 


\section{(b) $\underline{\text { Conclusion }}$}

Generally, making peace and declaring such has not been legally contentious. That is, making peace by means of a treaty or other legal agreement. And announcing peace by means of a SI or proclamation. Today, the sovereign is not involved in making - or declaring - peace. However, Parliament should be - very much so. Thus, an Armed Forces Act should indicate that peace shall be:

- $\quad$ made by a 'treaty or other agreement';

- declared by means of a SI (indicating the date and time).

Also, that the FCDO (or such other ministry ${ }^{112}$ as is indicated in a SI) is responsible for the above.

\section{CROWN PREROGATIVE - MANAGEMENT OF THE ARMED FORCES}

In times past, when there was no standing army (or navy), the sovereign as commander-in-chief was responsible for the management - and operation - of the armed forces. However, the sovereign had no Crown prerogative to maintain a standing armed forces. Indeed, it was (mainly) for attempting to maintain a standing army, the reason why Charles I (1625-49) and James II (1685-8) both fell from power. After 1688, a standing army was maintained with the consent of Parliament, such consent being renewed on an annual basis, being the annual Mutiny Acts. ${ }^{113}$ Although the involvement of the sovereign as $\mathrm{C}$-in- $\mathrm{C}$ of his armed forces ended in the $18^{\text {th }}$ century, ${ }^{114}$ the legal fiction that the sovereign was in some way legally and practically responsible for its operation and maintenance continued (the armed forces, in those times, only comprising small, shire-based, (local) militias (formerly, called commissions of array) and a navy).

\section{(a) Historical Position}

Blackstone (writing in 1765) stated:

The king is considered... as the generalissimo, or the first in military command, within the kingdom. The great end of society is to protect the weakness of individuals by the united strength of the community: and the principal use of government is to direct the united strength in the best and most effectual manner, to answer the end proposed. Monarchical government is allowed to be the fittest of any for this purpose: it follows therefore, from the very end of it's institution, that in a monarchy the military power must be trusted in the hands of the prince. In this capacity therefore, of general of the kingdom, the king has the sole power of raising and regulating fleets and armies. ${ }^{115}$

Chitty (writing in 1820) stated:

As the constitution of the country has vested in the king the right to make war or peace, it has necessarily and incidentally [been] assigned to him on the same principles the management of the war; together with various prerogatives which may enable $[\mathrm{HM}]$ to carry it on with effect. Thus the king is at the head of his army and navy, is alone entitled to order their movements, to regulate their internal arrangements, and to diminish, or, during war, increase their numbers, as may seem to $[\mathrm{HM}]$ most consistent with political propriety. ${ }^{116}$

\section{(b) Victorian Reforms}

During Victorian times, there was a process of dis-involvement of the Crown in the management of the armed forces (as noted, personal involvement of the sovereign as commander-in-chief had ended by 1793). This was summarised by Halsbury, Laws (1 $1^{\text {st }}$ ed, 1909) which stated:

Between 1794 and 1854 the duties relating to war were shared by the [SS] for War and the Colonies (whose office was created in 1794) and the Home Secretary, the office of Secretary at War (created in the reign of Charles II) existing side by side with these...At the time of the Crimean war, in 1855, an additional [SS] for the War Department was created whose office was combined with that of the Secretary at War, and the Colonial Secretary was relieved of his war duties. The Office of Secretary at War was finally abolished in 1863, his duties becoming amalgamated

\footnotetext{
${ }^{112}$ For example, the Ministry of Justice. It would not seem appropriate the MOD be in charge of the same.

${ }^{113}$ Chitty, n 7, p 46 'But the constitution has, with the wisest jealousy, ordained that a standing force is not legal in time of peace, unless by consent of Parliament. During peace the king has therefore no legal authority or prerogative to keep an army on foot. However, as remarked by Sir W[illia]m Blackstone, it has for many years past been annually judged necessary by our legislature, for the safety of the kingdom, the defence of the possessions of the Crown of Great Britain, and the preservation of the balance of power in Europe, to maintain even in time of peace a standing body of troops of troops, under the command of the Crown; who are however ipso facto disbanded at the expiration of each year, unless continued by Parliament.'

${ }^{114}$ Munro, n 20, p 269 'as with acts involved in the negotiation of or the control of the armed forces, for example, the sovereign has no part to play at all, but the powers are purportedly exercised in his or her name. Thus, as to the largest class of prerogatives, the monarch today is little more than a cypher.' (italics supplied)

${ }^{115}$ Blackstone, n 27, vol 1, p 254. Blackstone cited 13 Car 2 c 6 (1661) (rep), see n 302 'Forasmuch as within all [HM's] realms and dominions the sole supreme government, command, and disposition of the militia, and of all forces by sea and land, and of all forts and places of strength is, and by the laws of England ever was, the undoubted right of [HM] and his royal predecessors, kings and queens of England, and that both or either of the Houses of Parliament cannot nor ought to pretend the same'. This wording paid lip-service to the Crown prerogative. However, in his reign (and that of James II, 1685-8) there was no standing army because Parliament prevented it. And after 1689, the army was a standing army regulated by annual Mutiny Acts. As for the old shire militia (abolished in 1907), see 15.

${ }^{116}$ Chitty, n 7, p 45.
} 
with those of the [SS] for War (Secretary at War Abolition Act 1863...The present interior organisation of the War Office [i.e. in 1909] dates from the year 1904, when the system of dual control exercised since 1855, with regard to military administration, by the [SS] for War, and the [C-in-C], gave place to the present distribution of administrative duties between the [SS] for War and other members of the Army Council, whilst the executive duties of inspection formerly exercised by the [C-in-C], in addition to his administrative duties at the War Office, were decentralised or separated entirely from the administrative duties now exercised by the Army Council, and were handed over to the Inspector-General of the Forces, assisted by seven subordinate inspectors for the different branches of the services(s). ${ }^{117}$

\section{(c) One Ministry and Minister - MOD}

By 1931, there had been further consolidation and - although Wade (in 1931) indicated that the Crown prerogative in relation to the command of the forces was still 'largely uncontrolled' by statute - this was only technically so, by way of a legal fiction. The reality - which he accepted - was that the administration and movement of troops was undertaken by ministers. Thus, he stated:

The royal prerogative in relation to the command of the forces is still largely uncontrolled by statute. Even in relation to the army (and the air force), to which the Army Act applies, the prerogative is all important as regards administration and movement of troops. This branch of the prerogative is exercised through civilian cabinet ministers composed partly of service members and partly of civilians. ${ }^{118}$ (italics supplied)

Halsbury (in 2014) stated:

The supreme government and command of all forces by sea, land and air, and of all defence establishments is vested in the Crown by prerogative right at common law $^{119}$ and by statute. The monarch has, however, long ceased to exercise the supreme command in person... The formulation and general application of a unified policy relating to the armed forces as a whole and their requirements is the duty of the [SS] for Defence, who is a member of the cabinet... ${ }^{120}$

Also:

Although the supreme command and governance of the armed forces are vested in the Crown at common law and by statute, most matters relating to them are today primarily regulated by statute, for example the raising or embodying of the regular, reserve, territorial and auxiliary forces and their subjection, when raised or embodied, to special codes of military or naval discipline ; the general mode of enlistment and term of service of soldiers, sailors and airmen, with many other matters relating to the pay, pensions, decorations, effects, accommodation, privileges and exemptions, and civil duties and liabilities of soldiers, sailors and airmen; and the requisitioning of vehicles. The general administration of the Acts relating to these matters is controlled by the [MOD]. (italics supplied $)^{121}$

These statements reflect the modern reality of the armed forces. They are managed and controlled, at the apex, by the MOD, headed by the Secretary of State for Defence. This is as it should be in peace time. And, indeed, even in war time, given modern war, it is vital that there be a clear chain of command - with one ministry and one minister controlling the three disparate armed forces (army, navy, air force). Also, with the MOD minister reporting to cabinet and to the PM - who are both accountable to Parliament. Thus, in Sunkin (1999), Rowe stated:

In the absence of a constitution, the legal status of the armed forces in the [UK] has gradually evolved from a body under the total control of the Crown based on the royal prerogative, subject to parliamentary approval as to the raising and keeping of an army (and subsequently all three services) in peace time, to one where it is subject to judicial decisions both within and without the [UK], along with regular parliamentary scrutiny. ${ }^{122}$

\section{(d) $\underline{\text { Conclusion }}$}

The Crown prerogative in respect of the management, and control, of the UK's armed forces should be abolished. It is too opaque and too grounded in the past. Thus, legislation should make it clear (this, being the reality) that the MOD is the ministry charged with the management, control and operation of the UK's armed forces as well as the reserve forces (which includes the territorial army) ${ }^{123}$ - just as the FCDO should be responsible for the

\footnotetext{
${ }^{117}$ Halsbury, Laws, (5 ${ }^{\text {th }}$ ed), n 6, vol 20, pp 92-3.

${ }^{118}$ Wade, n 12, p 326. He continued 'The First Lord of the Admiralty is responsible to Parliament and to the king for the navy and is the political chief of the Board of Admiralty. The army is administered by the [SS] for War at the head of the War Office. The king is, however, technically the [C-in-C] of all the forces of the Crown.' (italics supplied)

119 This is only technically so. Thus, the common law Crown prerogative had become a statutory one by 1662 (in the case of the shire militia) and 1689 in the case of a standing professional army (whose operation, from the outset, was statutory).

${ }^{120}$ Halsbury, Laws, (5 ${ }^{\text {th }}$ ed), n 6, vol 20, p 575.

${ }^{121}$ Ibid, p 574.

${ }^{122}$ M Sunkin \& S Payne, The Nature of the Crown. A Legal and Political Analysis (OUP, 1999), p 281.

${ }^{123}$ Halsbury, Laws, n 6, (5 ${ }^{\text {th }}$ ed) vol 20, p 577 'Reserve forces are maintained by [HM] under the terms of the Reserve Forces Act 1996 and comprise the Royal Fleet Reserve, the Royal Naval Reserve and the Royal Marines Reserve ('the reserve naval and marine forces'), the Army Reserve and the Territorial Army ('the reserve land forces')...[HM] may by order signified under the hand of the [SS] make orders with
} 
conduct of the UK's foreign relations (foreign diplomacy). ${ }^{124}$ Thus, legislation should provide something to the following effect:

\section{Ministry of Defence (MOD)}

(1) The MOD is responsible for all matters relating to the military defence of the:

(a) UK; and the

(b) British Territories

In particular, for the matters referred to in ss 1-11 and 16-18, save where legislation provides otherwise.

(2) Any Crown prerogative in respect of (1) is abolished.

\section{MOD Accountable to Parliament}

(1) The MOD is accountable to Parliament.

(2) Any accountability of the MOD to the Crown is abolished.

\section{3. $\underline{\text { AF and TA }}$}

(1) The MOD is responsible for the:
(a) command;
(b) management;
(c) control;
(d) administration;
(e) regulation;
(f) operation;
(g) deployment;
(h) employment, and
(i) discipline

of the AF and the TA in the

(i) UK;

(ii) British Territories; and

(iii) abroad

save where legislation provides otherwise.

(2) Section 3(1)(a)-(g) includes reference to all:
(a) Military Land;
(b) Military Installations; and
(c) Military Equipment,

save where legislation provides otherwise.

(3) Any Crown prerogative in respect of (1) and (2) is abolished.

\section{CROWN PREROGATIVE - MANAGEMENT \& OPERATION OF MILITARY INSTALLATIONS}

(a) Background

The management and operation of the UK's armed forces by virtue of the Crown prerogative included the management, and operation, of their buildings and installations which, in early times, comprised forts (fortifications), castles, barracks and other military installations (sometimes, generically called 'places of strength '). Thus Blackstone (in 1765), referring to an Act of Charles II of 1661 which stated:

This statute, it is obvious to observe, extends not only to fleets and armies, but also to forts, and other places of strength, within the realm; the sole prerogative as well of erecting, as manning and governing of which, belongs to the king in his capacity of general of the kingdom. ${ }^{125}$

Chitty (in 1820) stated:

On similar grounds [to his prerogative to conduct war] the king is solely entitled to erect, fortify, and govern forts and other places of strength, within his dominions. ${ }^{126}$

Moving forward to modern times, Halsbury (in 2014) stated:

respect to the government and discipline of any reserve force and all other matters and things relating to that force, except pay, bounty and allowances, subject to any order or regulation being laid before each House of Parliament after being made.'

${ }^{124}$ See McBain, n 3 (BTFRA).

${ }^{125}$ Blackstone, n 27, vol 1, p 255 referring to13 Car 2 [st 1] c 6 (1661), see n 302.

${ }^{126}$ Chitty, n 7, p 45. 
Many wide and important powers relating to the armed forces are still retained by the Crown, whose discretionary authority is exercised on the advice of the [SS] for Defence, and through the recognised executive channels of the [MOD] and the Defence Council, the Admiralty Board, the Army Board and the Air Force Board. The powers left to the control of the Crown and its servants embrace such matters as the selection and appointment of the officers to whom the supreme command is delegated and the apportionment of their duties; the grouping and disposal of the various ships, battalions, and squadrons, and other naval, military or air force units at home and abroad, in time of peace or war; and generally all matters relating to the organisation, disposition, personnel, armament and maintenance of the naval, military and air forces. Whether all acts done and in the exercise of such powers and not authorised by statute are necessarily done by virtue of the royal prerogative is doubtful. ${ }^{127}$

The above focuses on the reality that the MOD manages, and operates, military installations, land and equipment as opposed to the legal fiction of the Crown doing so in the body politic.

\section{(b) Conclusion}

Today, it would seem axiomatic that the ministry in charge of the defence of UK and its armed forces should also be in charge of all military real property, installations and equipment. Thus, legislation should state something to the effect as provided in $\mathbf{1 0}(\mathbf{d})$.

\section{In conclusion, legislation should provide for the MOD to be responsible for the management and operation of all military installations, land (sites) and equipment.}

\section{LIMITATION ON CROWN PREROGATIVE - STANDING ARMY}

(a) Background

Until Stuart times, England (and Wales) had no standing army. That is, no regular army. Part of this related to the cost and need for the same. Being an island, England and Wales, after the Norman Conquest (1066), were rarely threatened by invasion. Also, in medieval times, armies (including those on the Continent) were, often, hired mercenaries, who were expensive. Thus, maintaining a standing army - in the absence of an efficient method of taxation - was beyond the resources of the sovereign. Further, there was no encouragement by Parliament for the maintenance by the sovereign of a standing army since the same could threaten the power of Parliament (indeed, its existence). The position of the navy was much the same. Up until the time of Henry VIII (1507-49), there were few ships and much reliance was placed on the ships of the Cinque Ports to effect naval battles. ${ }^{128}$ Besides, they were no threat to Parliament. However, Charles I (1625-49), Charles II (1660-85) and James II (1685-8) all sought to build up standing armies, with the intention of increasing their power at the expense of Parliament. Indeed, both the Civil War (1649-60) and the downfall of James II (1685-8) may be attributed in large measure to that. Further, the threat was real since:

- it was not generally denied, legally and otherwise, that the sovereign was the (executive) $\mathrm{C}$-in-C of the army (the militia). And, that they owed allegiance to the same; and

- the sovereign controlled the summoning, movement and operation of the armed forces.

However, in 1688, James II (1685-8) over-reached himself and fled. Prince William of Orange and his wife Mary became joint sovereigns and this was recognised in the Bill of Rights 1688. More especially, the Bill of Rights 1688 provided (and it still does) that:

The raising and keeping a standing army ${ }^{129}$ within this kingdom in time of peace unless it is with the consent of Parliament is against [the] law. (italics supplied)

The effect of this was the need for Parliament to annually consent to the keeping of a standing army. ${ }^{130}$ As Amos pointed out in 1880, this was a compromise:

It was at one time held that the management of the army was the point of contest between the rival departments of the constitution, Parliament and the Crown. A long-standing compromise has manifested itself in the passing of the Annual Mutiny Act (lately amended and to some extent transformed); and in the cautious enumeration of the number of soldiers to be embodied, and the sparse dealing out of supplies needed for military operations. ${ }^{131}$

\footnotetext{
${ }^{127}$ Halsbury, Laws, n 6, (5 $5^{\text {th }}$ ed), vol 20, p 574. As Stroud noted (in 1903) n 33 (military purposes) 'The Military Lands Act 1892 s 43 'Military Purposes' includes rifle or artillery practice, the building and enlarging of barracks and camps, the erection of butts targets batteries and other accommodation, the storing of arms, military drill, and any other purpose connected with military matters approved by the [SS].'

${ }^{128}$ See generally, GS McBain, n 43, pp 53-4. Also GS McBain, The Charters of the Cinque Ports - Are they still Needed? (2013) Review of European Studies, vol 5, no 2, pp 90-126.

${ }^{129}$ This provision was not designed to deal with a navy (and was prior to the development of an air force).

${ }^{130}$ Wade, n 12, p 318 'This provision was not due so much to the objection to military service as to the realisation that the army might be dangerous to the liberty of the subject in the hands of an unwise ruler.'

${ }^{131}$ Amos, $n$ 32, p 392. Also, 385-7. The first Mutiny Act was in 1689 and passed to meet an immediate peril. It was, as Dicey noted, $n 15, p$ 297 a classic compromise (fudge). A compromise between 'The belief... of our statesmen down to a time considerably later than the Revolution of 1689 was that a standing army must be fatal to English freedom, [and] yet very soon after the revolution it became apparent that the existence of a body of paid soldiers was necessary to the safety of the nation'.
} 
After 1793, when the sovereign was no longer executive C-in-C, the need for annual consent to a standing army was, strictly, unnecessary since the sovereign could not demand that the army follow his orders and continue to assemble, contrary to the will of Parliament. However, because the Crown (the sovereign in the body politic) was still involved in the calling, organisation and operation of the army, it is understandable that the compromise of an annual confirmation was continued as a matter of rote and to satisfy the Bill of Rights $1688 .{ }^{132}$ This has continued and the position for the armed forces is stated in Halsbury (in 2014):

The Crown is expressly prohibited from raising or keeping a standing army within the kingdom in time of peace unless with the consent of Parliament...The necessary authority for the maintenance of the military forces to be employed for the safety of the [UK] and the defence of the possessions of the Crown and for keeping discipline in them is supplied annually by statute or [OIC]. The raising and maintenance of the Royal Air Force are authorised by a permanent Act, but as the Armed Forces Act 2006, by which discipline is enforced, expires annually, annual legislation by statute or [OIC] is needed for the continuance of the air force, in the same way as for the army. The regular naval forces are maintained by the Crown without any direct statutory authority, none being required by the law of the constitution. Their discipline is provided for the Armed Forces Act 2006, which expires annually unless continued in force year by year by [OIC] according to the same rules applicable to the army and the air force. ${ }^{133}$

This curious compromise, therefore, resulted in the fact that the army was ' $n o t$, in theory, a standing army.' 134 However, in practice, since 1689, it has been a standing army and such is much needed for the defence of the UK, including today. Thus, today, it is appropriate to consider whether this legal fiction can be dispensed with if the Crown (including the sovereign) no longer has control of the same. ${ }^{135}$

\section{(b) $\underline{\text { Conclusion }}$}

Obviously, if legislation makes it clear that:

- the sovereign has no executive role in relation to the armed forces; and

- any Crown prerogative relating to the management and operation of the armed forces is abolished,

the section of the Bill of Rights 1688 cited in (a) above is otiose. The easiest way of achieving this is for legislation to state that the armed forces shall continue in existence until Parliament resolves otherwise.

\section{In conclusion, legislation should provide for the continuing existence of the armed forces until Parliament resolves otherwise.}

\section{CROWN PREROGATIVE - WAR TIME - TRADING WITH THE ENEMY}

\section{(a) Background}

Doubtless, from the earliest times, once war was declared, trading with the enemy was prohibited by the Crown. This would have been a relatively easy thing to do. The Crown controlled the establishment and operation of all ports. Thus, it could shut the same. This was done, fairly often, in the time of Edward I (1272-1307) and Edward II (1307-27) when there was war (or threatened war) with France. Thus, they closed all ports to traffic. ${ }^{136}$ In those times, there were few sea ports in any case and the main port for continental traffic was at Dover (which, also, had the only decent made up road to London, with messenger posts). In the case of war, trading with the enemy was a hazardous enterprise anyway since a person could be guilty of high treason under the Treason Act 1351 (aiding the enemy, still extant). ${ }^{137}$ As to this Crown prerogative, Chitty (writing in 1820) stated:

During war, trading with an enemy is illegal; but as observed by Sir W Scott, ${ }^{138}$ 'it is indubitable that the king may, if he please, give an enemy liberty to import' (that is, when the navigation, or other statute laws, do not expressly forbid such importation). 'He may, by his prerogative of declaring war and peace, place the whole of a foreign country, in a state of amity, or, a fortiori, he may exempt any individual from the operation of a state of war.' But the licence to enable an enemy to import goods must be express, for any enemy will not be protected by a general

\footnotetext{
${ }^{132}$ Wade, n 12, p 319 who noted that the necessity for an annual act was 'in order to suspend for the time being the unrepealed provision of the Bill of Rights.' For a change so that Service Discipline Acts would continue for 5 years see Rowe, pp 268-9 in Sunkin, n 122.

${ }^{133}$ Halsbury, Laws, n 6, ( $5^{\text {th }}$ ed), vol 20, para 564. Ibid, para 560 'The government, or in traditional terms the Crown or its ministers, is prevented from exercising despotic power by means of military force because it is not permitted to raise or keep a standing army within the kingdom in time of peace without the consent of Parliament.'

${ }^{134}$ Chalmers (in 1936), n 11, p 201.

135 The Mutiny Acts continued until 1881 when the Army Act 1881 was enacted. It comprised, effectively, a military code and (probably) at that time it should have been considered whether annual renewal could not be better formulated.

${ }^{136}$ In these times, anyway, sea travel to (and from) England was only during the spring and summer, in winter it was too hazardous). Thus, the fighting season (on land or water with France) was only then (in the case of Scotland, it was the same, in the case of land, due to the state of the roads).

${ }^{137}$ In the case of London, it was a walled city since Roman times, with only 7 gates and a couple of landings (ports), at which all foreigners paid a toll to sell their goods. In war time, with the gates closed, trade would have been impossible in practice save in the case of foreign merchants who had a 40 day period of residence under Magna Carta.

${ }^{138}$ Chitty referred to 2 Rob R 162 . Also to 1 East 486.
} 
licence, and it has not been usual to grant licences to an enemy. The right itself is established by the common law; ${ }^{139}$ and in the case of Vandyke $v$ Wintmore, ${ }^{140}$ Lord Kenyon said, 'though the king may, at common law, license a trading with an enemy's country, yet he may also qualify this licence, in which case the parties seeking to protect themselves under it must conform to its regulations'... ${ }^{141}$

However, Chitty also noted that as well as the Crown prerogative, Orders in Council were being made under statutory powers in respect of trading with the enemy. Thus, he stated:

Though we have seen that the king has not in general, by virtue of his prerogative, a power to dispense with the common law, or any legislative provision; yet it has been usual, during the war to give the king in council [i.e. the privy council] a power of modifying or dispensing with such provisions as it may be found expedient, in particular conjunctures, to alter or suspend; for the interests of commerce being of so variable a nature, and depending so much on circumstances suddenly arising, it would be very difficult, not to say impossible, during war, to make them generally subject to any permanent legislative provision. ${ }^{142}$ The power to make these [OIC], and to grant licences in pursuance of them being derived from Acts of Parliament, is of a limited nature, and cannot be extended further than the acts themselves permit. The construction of licences granted by virtue of the king's prerogative, will in general be applicable to licences founded on these statutes [Acts]. ${ }^{143}$

Halsbury ( $1^{\text {st }}$ edition in 1909) stated:

When war with a foreign state has been commenced either by a formal declaration or by actual hostilities, the effect is to prohibit all commerce and intercourse between British subjects resident in British territory and the subjects of that state, or with persons residing there, and contracts entered into with such persons after war has commenced are void, whilst executor contracts entered into before the war are avoided. ${ }^{144}$

Very similar wording was employed by Halsbury (in 2014) when it stated:

When war with a foreign state has been commenced either by a formal declaration or by actual hostilities, the effect is to prohibit all commerce and intercourse between British citizens resident in British territory and the subjects of that state, or with persons residing there. ${ }^{145}$

Halsbury (in 2014) also noted that, while trading with the enemy was an offence at common law, it was also a statutory offence under the Trading with the Enemy Act 1939 and the Emergency Laws (Misc. Provisions) Act 1953.

\section{(b) Legislation}

The common law position on trading with the enemy was, effectively, superceded by the Trading with the Enemy Act 1939, which is still extant. Section 1 (penalties for trading with the enemy) provides:

(1) Any person who trades with or attempts to trade with the enemy within the meaning of this Act shall be guilty of an offence of trading with the enemy, and shall be liable - (a) on conviction on indictment, to imprisonment for a term not exceeding [7] years or to a fine or to both such imprisonment and a fine, or (b) on summary conviction, to imprisonment for a term not exceeding [12] months or to a fine not exceeding [ $£ 500]$, or to both such imprisonment and such fine; and the court may in any case order that any goods or money in respect of which the offence has been committed shall be forfeited. (2) For the purposes of this Act a person shall be deemed to have traded with the enemy - (a) if he has had any commercial, financial or other intercourse or dealings with, or for the benefit of, an enemy, and, in particular, but without prejudice to the generality of the foregoing provision, if he has - (i) supplied any goods to or for the benefit of an enemy, or obtained any goods from an enemy, or traded in, or carried, any goods consigned to or from an enemy or destined for or coming from enemy territory, or (ii) paid or transmitted any money, negotiable instrument or security for money to or for the benefit of an enemy or to a place in enemy territory, or (iii) performed any obligation to, or discharged any obligation of, an enemy, whether the obligation was undertaken before or after the commencement of this Act; or (b) if he has done anything which, under the following provisions of this Act, is to be treated as trading with the enemy: and any reference in this Act to an attempt to trade with the enemy shall be construed accordingly. Provided that a person shall not be deemed to have traded with the enemy by reason only that he has - (i) done anything under an authority given generally or specially by, or by any person authorised in that behalf by, a [SS], the Treasury or the Board of Trade, or (ii) received payment from an enemy of a sum of money due in respect of a transaction under which all obligations on the part of the person receiving payment had already been performed when the payment was received, and had been performed at a time when the person from whom the payment was received was not an enemy. (3) Any reference in this section to an enemy shall be construed as including a reference to a person acting on behalf of an enemy. (3A) In any proceedings for an offence of trading with the enemy, the fact

\footnotetext{
${ }^{139}$ Chitty referred to H Rolle, Abridgment (1668), vol 2, p 173, pl 3 and 8 TR 550. Also, to J Chitty, Law of Nations (1833), p 250.

${ }^{140}$ Chitty referred to 1 East 475.

${ }^{141}$ Chitty, n 7, p 171. Chitty continued 'During the latter part of the late war [Napoleonic Wars 1803-15] numerous questions arose on the construction of licences granted by the Crown. The general leaning in all the courts was, to give them a comprehensive and liberal construction.' He also noted, p 172 'The conclusion of a peace necessarily destroys a licence, it then having no subject-matter to act upon.'

${ }^{142}$ Ibid, p 172. Chitty referred to 43 Geo 3 c 153, ss 15 \& 16; 45 Geo 3 c 34; 46 Geo 3 c 111; 47 Geo 3 sess 2 c $27 ; 48$ Geo 3 c 37 , 126 ; 49 Geo 3 c 25, 60 (all rep).

143 Ibid.

${ }^{144}$ Halsbury, Laws, n 6, (1 ${ }^{\text {st }}$ ed, 1909), vol 6, p 443.

${ }^{145}$ Halsbury, Laws, n 6. (5 $5^{\text {th }}$ ed), vol 20, para 543.
} 
that any document has been despatched addressed to a person in enemy territory shall, unless the contrary is proved, be evidence, as against any person who was a party to the despatch of the document, that the person to whom the document was despatched was an enemy. (4) A prosecution for an offence of trading with the enemy shall not be instituted in England or [NI] except by, or with the consent of, the [DPP] or the [AG] for [NI], as the case may be...

Other ss of the Act deal with the following;

s 2 (definition of enemy); 3 (inspection and supervision of businesses); $3 \mathrm{~A}$ (power to control and wind up certain businesses); 4 (transfer of negotiable instruments and choses in action by enemies); 5 (transfer and allotment of securities); 6 (purchase of enemy currency); 7 (collection of enemy debts and custody of enemy property); 9 (false statements and obstruction); 10 (offences by corporations); 11 (expenses of and exercise of powers by Board of Trade), 12 (evidence of authority or sanction of [SS], Treasury or Board of Trade); 13 (Scotland); 14 (Extension of Act to colonies); 15 (interpretation), 16 (savings of rights of the Crown).

It may be noted that this Act contains a useful definition of 'enemy', s 2 stating:

(1) Subject to the provisions of this section, the expression "enemy" for the purposes of this Act means - (a) any State, or Sovereign of a State, at war with [HM], (b) any individual resident in enemy territory, (c) any body of persons (whether corporate or unincorporate) carrying on business in any place, if and so long as the body is controlled by a person who, under this section, is an enemy, (d) any body of persons constituted or incorporated in, or under the laws of, a State at war with [HM]; and (e) as respects any business carried on in enemy territory, any individual or body of persons (whether corporate or unincorporate) carrying on that business; but does not include any individual by reason only that he is an enemy subject. (2) The Board of Trade may by order direct that any person specified in the order shall, for the purposes of this Act, be deemed to be, while so specified, an enemy.

Section 15 also states:

In this Act the following expressions have the meanings hereby respectively assigned to them: - "enemy subject" means - (a) an individual who, not being either a British subject or a British protected person, ${ }^{146}$ possesses the nationality of a State at war with $[\mathrm{HM}]$, or (b) a body of persons constituted or incorporated in, or under the laws of, any such State; and "enemy territory" means any area which is under the sovereignty of, or in the occupation of, a Power with whom [HM] is at war, not being an area in the occupation of $[\mathrm{HM}]$ or of a Power allied with $[\mathrm{HM}]$.

These definitions are useful when considering the rights of an enemy subject, for the purpose of their being able to enter (or leave or remain) in the UK during warfare. The Act of 1939 has superceded the common law prerogative and although the Act contained a saving of the Crown prerogative (s 16), this was otiose it is suggested. In any case - since things have moved on since 1939 - the sections of the Act of 1939 should be modernised to take account of modern payment methods etc.

\section{(c) Conclusion}

Any Crown prerogative relating to trading with the enemy should be abolished since the Act of 1939 was intended to supercede it. And, the Act of 1939 (as modernised) should be placed in legislation.

In conclusion, any Crown prerogative with respect to trading with the enemy should be abolished and the 1939 Act (as modernised) should be placed in a Crown Act or Armed Forces Code (Act).

\section{CROWN PREROGATIVE - EXPORTING MILITARY MATERIAL}

(a) Background

An asserted Crown prerogative was that the Crown could prohibit the export of military material such as gunpowder and military weapons. Blackstone (in 1765) said little about this, merely stating:

To this branch of the prerogative [i.e. military prerogatives] may be referred the power vested in [HM], by statutes 12 Car II c 4 and 29 Geo II c 16 of prohibiting the exportation of arms or ammunition out of this kingdom, under severe penalties... ${ }^{147}$

The first Act referred to was that of a Subsidy granted to the king of Tonnage and Poundage $1660 ;{ }^{148}$ the second was the Exportation Act $1756 .{ }^{149}$ These were powers granted by Parliament to the Crown. Thus, they do not refer to any distinct Crown prerogative as such. Rather, they constitute examples of Parliament empowering the Crown to act. Also, they were not passed with reference to any war. Thus, this was peace time legislation in its purport. The Act of 1660, s 12 stated:

it shall be free and lawful for [HM], and at any time when he shall see cause to do, and for such time as shall be therein expressed, by proclamation, to prohibit the transporting of gunpowder, or any sort of arms or ammunition, into any parts out of this kingdom; any thing in this Act contained to the contrary notwithstanding.

\footnotetext{
${ }^{146}$ This category appears to be obsolete.

${ }^{147}$ Blackstone, n 27, vol 1, p 255.

${ }^{148}$ The long title was 'A subsidy granted to the king of Tonnage and Poundage, and other sums of money, payable upon Merchandise exported and imported.'

${ }^{149}$ The long title was 'An Act to empower [HM] to prohibit the exportation of saltpetre, and to enforce the law for impowering [HM] to prohibit the exportation of gunpowder, or any sort of arms and ammunition; and also to impower [HM] to restrain the carrying coastwise of saltpetre, gunpowder, or any sort of arms or ammunition.'
} 
As for the Act of 1765, it stipulated:

$[\mathrm{HM}]$ may, by proclamation, or [OIC], when he shall see cause, and for such time as shall be therein expressed, prohibit the exporting, or attempting to export, saltpetre out of this kingdom, in such manner and under such restraints as he shall think fit.

That said, it may be that the Crown did have a prerogative to prohibit the export of military weapons (personal body armour) in very early times. Thus, the Assize of Arms 1181, s 8 stated, inter alia:

No one [freeman] shall carry arms out of England except by the command of the lord king: no one is to sell arms to another to carry out of England; nor shall a merchant or any other man carry them out of England. ${ }^{150}$

\section{(b) Contraband of War}

In the context of war, the words 'contraband of war' tended to be used as a generic term. One to cover military hardware and other implements useful in war. A later legal dictionary (Stroud, 1903) was to define it as follows:

'Contraband of War', it is submitted, means, all those things which by international law (or, as in practice it would seem, by a belligerent power, when it is strong enough) may be deemed, directly or indirectly, useful to an enemy for the purpose of an existing war. ${ }^{151}$

\section{(c) A Sub-Prerogative?}

The precise provenance of any Crown prerogative to prohibit the export of military hardware - whether in peace or war time - is dubious. Chitty appears to have treated it as a sub-prerogative. Writing in 1820, he stated the context of the same, to justify the right of the Crown to interfere with commercial trade:

Though we have seen that the king has not in general, by virtue of his prerogative, a power to dispense with the common law, or any legislative provision [a reference to the Crown prerogative to dispense with the common law or legislation]; yet it has been usual, during the war, to give to the king in council [i.e. to the privy council] a power of modifying or dispensing with such provisions as it may be found expedient, in particular conjunctures, to alter or suspend; for the interests of commerce being so variable a nature, and depending so much on circumstances suddenly arising, it would be very difficult, not to say impossible, during war, to make them generally subject to any permanent legislative provision. The power to make these orders of council, and to grant licences in pursuance of them being derived from Acts of Parliament, is of a limited nature, and cannot be extended further than the Acts themselves permit. The construction of licences granted by virtue of the king's prerogative, will in general be applicable to licences founded on these statutes.

Thus, it seems Chitty was asserting that the Crown prerogative to prohibit the export of military goods was an example of the Crown's dispensing power. In this case, to dispense with the general freedom of parties to trade at common law. However, Chitty went on to state:

We have also seen, that in cases of positive state necessity, the Crown has the power of laying on a general embargo; and, on the same principle of political emergency and absolute necessity, on which embargoes are justifiable, we may rest the king's power to make new declarations of contraband, and to prohibit the trading in articles which are termed contraband of war, as arms, ammunition, horses, timber for ship building, naval stores, provisions, at least when manufactured and fit for consumption, and in general any implements useful in war. When, during a war, neutral merchants etc assist the enemy with such articles, they are liable to seizure and confiscation. As observed by Lord Erskine. ${ }^{152}$ 'The king having, by his prerogative, the power to promulgate who are his enemies, is bound to watch over the safety of the State; he may, therefore, make new declarations of contraband, when articles come into use, as implements of war, which were before.' 153

Therefore, it seems that - despite the above - Chitty believed that the Crown's power to prohibit the export of contraband of war rested on the Crown's power to impose an embargo.

- if so, this sub-prerogative could only apply during war time since Chitty accepted that an embargo in peace time was illegal;

- the only authority on which Chitty rested his case on was an extra-judicial observation of Lord Erskine. Such was a poor basis since the latter referred not to any Crown prerogative to dispense (or in respect of embargo). Rather, to the prerogative of the sovereign to make war (thereby, categorising his 'enemies').

Further, the above rationale of Chitty rests uneasily with prior statements made by him as to the freedom of trade. Thus, he stated:

it may be laid down as a general rule, that the king does not possess any general common law prerogative with respect to foreign commerce...A general discretionary power of restraining, regulating and superintending foreign

\footnotetext{
${ }^{150}$ C Stephenson \& FG Marcham, Sources of English Constitutional History (1937), p 86. There is also a prohibition of the export of ships or timber, $\mathrm{s} 12$.

${ }^{151}$ Stroud, n 33, (contraband of war).

${ }^{152}$ Chitty, n 7, p 173, referred to a speech by the same on 8 March 1808, on the Orders in Council. See Corbett, Parliamentary Debates, vol 10, pp 958-9.

${ }^{153}$ Ibid, p 172.
} 
commerce is not assigned by the common law to the king... The freedom of trade and the general inability of the king to restrain it, or to express any discretionary power on the liberty of the subject in this respect, by virtue of his common law prerogatives, and independently of any legislative authority, appears to be clear both on sound constitutional principles and from the authorities of the first weight and character. ..It is on this principle also that embargoes which occasion a suspension of commercial intercourse, are not legal at common law, except when they operate for the public good and safety; being used in time of enmity [i.e. war] and threatened hostilities [i.e. threatened war] and on an emergency, and not for the private advantage of a particular trader or company. ${ }^{154}$

Chitty, then, cited Hale in his work, De Portibus Maris (written in the 1640's) ${ }^{155}$ who stated:

it will appear from the several Acts of Parliament that have been made for the support and increase of trade, and for the keeping of the sea open to foreign and English merchants and merchandise, that there is now no other means for the restraint of exportation or importation of goods and merchandises in time of peace, but only when and where an Act of Parliament puts any restraint. ${ }^{156}$ (italics supplied)

In light of the above, it is dubious that there really is (or was) any Crown prerogative to prohibit or embargo the export of goods (including military goods, i.e. contraband of war) in peace time. Rather, the same could only be achieved by legislation (see (a)) empowering the sovereign to prohibit, which is not a Crown prerogative. And, was there one in war time? The authority for this is very thin.

\section{(d) Export Control Act 2002}

It would appear that any prohibition on the export of goods (including, so-called 'contraband of war') since - at least, 1660 - has been effected by legislation, not through the exercise of any Crown prerogative. The current legislation, the Export Control Act 2002, is extensive and covers the field. Thus, s 1 (export controls) provides:

(1) The [SS] may by order make provision for or in connection with the imposition of export controls in relation to goods of any description.

(2) For this purpose 'export controls', in relation to any goods, means the prohibition or regulation of their exportation from the [UK] or their shipment as stores.

Further, a Schedule, s 1, expressly provides that export (and trade) controls may be imposed in relation to military equipment, goods on which military technology is recorded or from which it can be derived; or goods intended, designed or adapted for use in the development or production of military equipment or military technology. Further, today, prohibitions on the export (or import) of goods (including pursuant to sanctions) are made by way of SI. Thus, the need for any Crown prerogative to prohibit the export of military equipment (assuming that such exists) - whether in peace or war time, is otiose.

\section{(e) Conclusion}

The above asserted prerogative to impose export controls is an excellent example of why all Crown prerogatives should be abolished as obsolete or should now be re-stated in legislation (in which case they are not Crown prerogatives as such). The assertion of this Crown prerogative is based on a contradictory basis by Chitty and others. Further, it may be noted that - in 1766 - the Crown - by means of a proclamation - prohibited the export of corn (during scarcity). This was held to be illegal (as Chitty noted) and the owners of the embargoed ships and corn were iindemnified by an Act of Indemnity. ${ }^{157}$ This Act indicated that the Crown's order to impose an embargo on corn 'could not be justified by law.' ${ }^{158}$ Further, in a modern democracy, it would seem important that any import (or export) of goods - military or otherwise - should be subject to the review of Parliament and only passed pursuant to the aegis of the same.

In conclusion, legislation should abolish any Crown prerogative. And, provide that any prohibition on the import or the export of goods - including military equipment of any nature - should be effected by way of a SI.

\section{CROWN PREROGATIVES - COMPULSORY MALE ARMY SERVICE}

(a) Introduction

Was (and is) there a Crown prerogative to compulsorily require able-bodied men in the UK to undertake service in the army. That is, to compel enlistment against their will? ${ }^{159}$

Today, the only legal authorities for asserting such a Crown prerogative are Halsbury, Laws. Also, a case of naval impressment, Broadfoot (1743) in which Sarjeant Michael Foster gave judgment. As to these:

\footnotetext{
${ }^{154}$ Ibid, pp 163-5.

${ }^{155}$ See F Hargrave, Collectanea Juridica, Consisting of Tracts relative to the Law and Constitution of England (1791-2), pt 1 A Treatise in three Parts, De Jure Maris et Brachiorum eiusdem, De Portibus Maris, and concerning the customs of goods imported and exported.

${ }^{156}$ Chitty, n 7, p 165.

${ }^{157} \mathrm{Ibid}, \mathrm{p} 164$.

${ }^{158}$ Ibid.

${ }^{159}$ This subject has been considered in a shorter manner in McBain, $\mathrm{n} 43$, pp 54-5.
} 


\section{(i) $\underline{\text { Halsbury }}$}

Halsbury - in its first edition in 1909 - said that there was such a Crown prerogative. Able-bodied men could be forced to undertake military service in the army in the case of 'sudden invasion or dangerous rebellion'. 160 However, the source for this wording is statutory - the wording being taken from Pitt's Militia Act 1757, s 45. It referred to the shire militia being embodied in the case of:

actual [foreign] invasion or upon imminent danger thereof, or in the case of rebellion [i.e. civil war]. ${ }^{161}$

Thus, this legislation (now repealed) is no evidence of a Crown prerogative. Further, the Militia Act 1757 empowered the Crown to embody the shire militia in such cases. This is different to the Crown having a common law prerogative to do the same.

\section{(ii) Broadfoot's Case (1743)}

In support of its proposition, Halsbury referred to a judgment of Sir Michael Foster in a case, Broadfoot (1743). Yet, this case dealt with the navy, not the army. Thus, the few statements made by Foster in respect of conscription into the army were obiter. As it is Foster concluded:

I think the Crown hath a right to [i.e. to impress mariners in to the royal navy], whenever the public safety called for it. The same right it hath to require the personal service of every man able to bear arms in the case of a sudden invasion or formidable insurrection. The right in both cases is founded on one and the same principle, the necessity of the case in order to [secure] the preservation of the whole. ${ }^{162}$ (italics supplied)

As can be seen, Foster appealed to the 'necesssity of the case' (the Roman concept of 'salus populi [est] suprema $\left.l e x^{\prime}\right)^{163}$ as the sole support for his proposition. Why?

- Foster could find no caselaw giving the Crown a prerogative to conscript (that is, to compulsorily draft) subjects into the army. And, any examples he did give were statutory (and now repealed);

- Also, Foster must have known that 'lex salus' was (and is) not part of the English common law, which is based on custom. Further, lex salus was not a principle of Roman law as such. It derives from Cicero's work The Laws in which he was considering the legal nature of an ideal State. In the context of the rulers of such a state Cicero opined:

There shall be two magistrates with royal powers. Since they lead, judge, and confer, from these functions they shall be called praetors, judges, and consuls. In the field they shall hold the supreme military power; they shall be subject to no one; the safety of the people shall be their highest law. [militiae summum ius habento, nemini parento; ollis salus populi suprema lex esto]. ${ }^{164}$

Thus, this expression is no more than a personal assertion that the safety (welfare) of the Roman people should be the highest law (i.e. paramount). That is, the grundnorm of law.

\section{Thus, the purpose of this article is to show that there never was a Crown prerogative to conscript all able bodied subjects into the army against their will, post-1066.}

\section{(b) Grounds for Confusion: Raising the Army}

It should be noted - at the outset - that part of the problem in considering any Crown prerogative to conscript is the confusion surrounding it. After the Norman Conquest (1066) there was no standing army until 1689. Thus, soldiers for the army could be raised to fight by the Crown in the following 5 legal ways:

(a) tenurial military obligation (obsolete c. 1300 in practice, last used 1640, abolished in 1660); ${ }^{165}$

(b) hiring foreign mercenaries (at Crown cost); ${ }^{166}$

\footnotetext{
${ }^{160}$ The wording in Halsbury, Laws (1 $1^{\text {st }}$ ed, 1909), n 6, (5 $5^{\text {th }}$ ed), p 448 is: 'The Crown may also demand, and is entitled to, the personal services of every man capable of bearing arms [i.e. any able-bodied man] in case of sudden invasion or dangerous rebellion, but except on such occasions it has no power to compel enlistment.' A fn referred to 'Broadfoot's Case (1743) Fost 154 at 157-159, 175.

${ }^{161}$ There was also an Act of 1327 (see 15(o)). However, it only refers to 'the coming of strange [foreign] enemies into the realm' (i.e. foreign invasion) when the shire militias were required to fight outside their shires.

${ }^{162}$ M Foster, A Report of some proceedings on the Commission for the Trial of Rebels in the county of Surry and of other Crown Cases etc $\left(3^{\text {rd }}\right.$ ed, 1809), p 157. Also, $R v$ Broadfoot (1743) Foster 154 (168 ER 76) at p 158.

${ }^{163}$ Cicero, De Re Publica De Legibus (trans CW Keyes, Heineman, 1948). Also translated as 'Let the good of the people be the supreme law.' It may be noted that such a proposition is not part of the ancient XII Tables, EH Warmington, Remains of Old Latin, Lucilius, The Twelve Tables (Harvard UP, 1967).

${ }^{164}$ Ibid, pp 466-7. Also translated as 'Let the good of the people be the supreme law.' Foster realised this since, n 162, p 159 he stated 'A general immemorial usage not inconsistent with any statute, especially if it be the result of evident necessity and withal tendeth to the public safety, is, I apprehend, part of the common law of England.' Such is not saying that 'lex salus' (the necessity of the case, as he called it) is part of the common law of England. Further, any such immemorial usage to conscript for the army by any Crown prerogative (assuming the same existed) was superceded by Acts of 1662 and 1757 (see 15 (a), (t) \& (u)).

${ }^{165}$ It was effectively obsolete by c. 1315 when the last scutage was levied, see n 229 . However, sovereigns also tried to force ('distrain') rich people into becoming knights by way of getting them to pay in lieu in order to avoid any military service. See e.g. Stephenson, n 150, p 161 (Distraint of Knighthood).

${ }^{166}$ This was common for English battles fought abroad in medieval times. However, mercenaries were also used in England battles in the $12^{\text {th }}$ c. (mainly Flemings). The use of foreigners was hugely unpopular and later sovereigns tended not to use them in England.
} 
(c) voluntary enlistment (i.e. paid service at Crown cost, also called by 'indenture' or 'impressment'); ${ }^{167}$

(d) with the consent of Parliament (i.e. by means of legislation).

However, none of these constituted compulsory service by virtue of the Crown prerogative. Thus, in the case of (a), the Crown gave land and military protection to subjects in return for allegiance and the performance (in some cases) of military service (called 'knight service'). This was contractual. So too, were (b) and (c). In the case of (d), this was statutory. The only case where the Crown could compel military service was by:

(e) using the shire militias.

Yet, care must be taken in asserting that this was compulsory military service. The civil purpose of the shire militias was to 'keep the peace.' That is, to help punish breaches of the criminal law - by helping to arrest criminals and detect crime. In its military form, post-Conquest (1066), the shire ministers comprised able-bodied males aged 15-60 only (the age of 15 was raised from 12 in 1195). Thus, they did not comprise all subjects. Further, the shire militias were disbanded in 1907 and no longer exist. Also, by legislation, there were strict controls on the Crown, in any case, being able to summon the shire militias. This was:

(i) because they were required to have military weapons at home (to 'bear arms');

(ii) they had to be paid by the Crown;

(iii) they could only be required to fight within their shire (save in the case of a foreign invasion).

In the case of:

(i), the requirement to 'bear arms' was abolished in 1603;

(ii), an Act - the Confirmation of the Charters 1297 (still extant) - severely limited the Crown's power to make war since it prevented it the Crown from levying any tax ('task') to fund any war without the consent of Parliament;

(iii), was laid down in an Act of 1327.

As well as these pieces of legislation, an Act of 1351 (see 15(p)) prevented the Crown for raising troops for war other than by means of (a)-(e). Finally, an Act of 1662 (see 15(t), one not noted by Foster) provided for the shire militias to continue to exist. ${ }^{168}$ Thus, this legislation abolished any common law Crown prerogative to levy the shire militias (themselves disbanded for good in 1907). Unfortunately, none of these points were considered in detail by Halsbury or by Foster (on whom Halsbury based its proposition). That said, there is no doubt that the Crown imposed illegal compulsory service on the shire militias in violent times - such as:

- $\quad$ during the Wars of the Roses (1355-1485); ${ }^{169}$

- $\quad$ in the reign of Charles I (1625-49); ${ }^{170}$

- $\quad$ in the reigns of Edward I (1272-1307) and Edward II (1307-27). ${ }^{171}$

However, after 1660 - when Charles II (1660-85) returned from France after the Cromwellian period to reign - no sovereign sought to maintain an army illegally. That is, without the consent of Parliament.

Thus, any contention by Halsbury (and Foster) as to an existing Crown prerogative to impose compulsory army service on men - that is, to compel enlistment as Halsbury terms it - in the case of 'sudden invasion' or 'dangerous rebellion' is simply incorrect since any such power was ended by an Act of 1662. Further (in any case) the shire militias to which it applied were disbanded in 1907.

(c) Grounds for Confusion: Impressment

Another confusion has arisen through the inaccurate use of the word 'impressment'. This word, actually, refers to when men were recruited for the army (and navy) pursuant to a contract with them in which they agreed to serve

\footnotetext{
${ }^{167}$ For the uncertain meaning of 'impressment', see 15(c). Sometimes sovereigns paid (bribed) people to undertake army service by offering gifts, offices, see 19 Hen VII (1503), c 1 (rep). It does not deal with any general service obligation of subjects but imposes a punishment when persons granted offices by the sovereign do not then attend him in battle. The gist is: 'if any person... within this realm of England and Wales, having such offices, fees, or annuities, by any of his rehearsed gifts and grants, do not give their attendance on him [the king], when he shall fortune to go in wars in his person, in their said persons, as their duty binds them...they... [shall] forfeit and lose their said offices, fees, and annuities, and to....stand void [of the same] at the king's pleasure...' (spelling modernised)

${ }^{168} \mathrm{CM}$ Clode, The Military Forces of the Crown (1869), vol 2, $\mathrm{p} 8$ 'The impressment of soldiers [by which he meant compulsory conscription] by direct orders and under the sole authority of the Crown absolutely ceased after the revolution of 1688'. In fact, the date was 1660 since neither Charles I (1660-85) nor James II (1685-8) had a standing army and, thereafter, they were prevented from imposing (forcible) conscription by an Act of 1662 (see 15(t)) even if they had wanted to (they could have levied an army by the Crown paying and by voluntary enlistment - which was different - but they never had the money).

${ }^{169}$ In the Wars of the Roses, private armies (with retainers, dress (livery) and badges) were levied by great men (nobles) for the use of the Crown. However, these were private armies and, thus, illegal.

${ }^{170}$ Charles I (1265-49) sought to maintain a standing army in peace time illegally. It cost him his throne and his head.

${ }^{171}$ Edward II (1307-27) sought to levy the shire militias for fighting abroad illegally (in Scotland and in Gascony). It cost him his throne.
} 
in return for 'impressment money' (foreshortened to 'imprest' or 'prest' money). ${ }^{172}$ An older word(s) for it was service by 'indenture' (contract). Such voluntary enlistment was quite different from compulsorily requiring men to service in the army (and navy) without any asserted contract being entered into. Maitland (in 1887-8) stated:

The history of the word itself [impressment] is very curious - doubtless pressing suggests the notion of compulsion, physical restraint - and doubtless for a very long time past people have had this notion in their minds when they talked about impressments, pressing sailors, the press-gang and so forth. But it is, I believe, quite well established that the word originally bore a quite different sense. In the National Debt Act of 1870 (33 and 34 Vic, c 71, sec 14), one may read that the money issued for the payment of dividends is to be paid to the chief cashier of the bank by way of imprest. It is from impraestare - think of the French word preter - money is imprest when it is advanced for a specific purpose; and 'imprest money' was the sum advanced or given to soldiers and mariners upon enlistment. ${ }^{173}$

One would agree. That said, men were often tricked into army service by getting them drunk and, then, persuading them to take the 'king's shilling'. Or hiding it (or another coin) on them or other trickery. This was, then, treated as their having made a contract, the coin being a token of an agreement (an engagement) which they had voluntarily accepted. ${ }^{174}$ The misuse of this word 'impressment' can, often, be seen in the writings of historians and legal writers. They use the word 'impressment' when they actually mean to refer to:

(a) conscription (i.e. compulsory service) pursuant to legislation; or

(b) where men agreed to serve by voluntary enlistment on condition of being released from prison from debt or for crimes committed. ${ }^{175}$

Bearing in mind, then, these points of confusion, any asserted Crown prerogative to conscript (that is, to forcibly recruit or require enlistment) will now be considered by reference to Halsbury and to a case in which Sarjeant Foster gave judgment in 1743 (Broadfoot) - one of naval, not army, service.

\section{(d) Asserted Crown Prerogative - Halsbury}

Halsbury, Laws (1909) stated:

The Crown may also demand, and is entitled to, the personal services of every man capable of bearing arms [i.e. any able-bodied man] in case of sudden invasion or dangerous rebellion, but except on such occasions it has no power to compel enlistment. ${ }^{176}$

When this statement was made there was no air force in existence. Thus, it was referring to enlistment in the army or navy only. This statement was re-stated in later editions of Halsbury, with Halsbury (in 2014) stating:

The Crown may demand, and is entitled to, the personal services of every man capable of bearing arms in case of sudden invasion or dangerous rebellion, but except on such occasions it has no power, unless such a power is conferred by statute, to compel enlistment. ${ }^{177}$

As authority for this legal proposition. Halsbury (in both cases) cited Broadfoot's Case (1743) only. However, it is asserted this case of 1743 is no support for such a proposition.

\section{(e) Asserted Crown Prerogative - Broadfoot (1743)}

The opinion of the sole judge in the case, Sir Michael Foster, was obiter since the case concerned naval impressment only. Not impressment in the army which was different historically. Thus, Foster stated at the outset:

We are not at present concerned to inquire, whether persons may be legally pressed into the land-service... ${ }^{178}$

Further, when Foster considered army service in his judgment, he did so very briefly. And, he only referred to legislation governing the same (all now repealed) ${ }^{179}$ which (potentially) empowered the Crown to conscript. Forster was not referring to any common law Crown prerogative in the absence of such legislation - a point invariably overlooked. More especially, Foster seemed unaware of the position under Anglo-Saxon law and

\footnotetext{
${ }^{172} \mathrm{C}$ Sweet, A Dictionary of English Law $\left(1^{\text {st }} \mathrm{ed}, 1882\right)$ (imprest-money) 'is money imprested or advanced by the Crown for the purpose of being employed for its use.' For a statutory example of the use of this wording see 17 Car 1 c 28 (1641), see SR Gardiner, The Constitutional Documents of the Puritan Revolution 1625-1660 (1958), pp 242-5 ('every of them shall have such imprest money').

${ }^{173}$ Maitland, n 9, pp 461-2.

${ }^{174}$ The use of tokens to seal the bargain (contract) was age old. When exchanged between the parties, it signified that negotiations had been concluded and a contract made, with the token being the consideration for it. See also GS McBain, Abolishing the Doctrine of Consideration (2018) ILR, vol 7, no 1, pp 1-197.

${ }^{175}$ See n 322 .

176 See n 160.

${ }^{177}$ Halsbury, Laws, n 6, ( $5^{\text {th }}$ ed), p 555. A fn states: 'Broadfoot's Case (1743) Fost 154 at 157-159, 175. During the 1914-1918 war and since, this power was not resorted to by the Crown, which preferred to obtain the passing of Acts of Parliament imposing compulsory service.'

${ }^{178}$ See $n 162$.

${ }^{179}$ This is clear from Foster's statement, n 161, p 175, that compulsory land service could not be contrary to Magna Carta [1297] or to the principles of the British constitution, if 'temporary Acts' warranted it. This is correct. However, Foster accepted such temporary Acts (for both the army and navy) were 'By common consent and grant in Parliament.' Ibid, p 179. Thus, their provisions were statuory (including empowering the Crown) and not the exercise of any common law Crown prerogative. Thus, they - as well as all being repealed - are immaterial to the presented issue, which is whether the Crown has (and had) a common law prerogative to impose military service.
} 
(perhaps) his knowledge of army law - especially, of medieval armies - was scant. Thus, his statements need to viewed, today, in light of greater historical knowledge. In short, this case does not support (at all) the wording of the statement of Halsbury in 1909 (or in 2014). In this case of impressment in the navy, Foster stated:

I think the Crown hath a right to command the services of these people [i.e. to impress mariners into the royal navy], whenever the public safety called for it. The same right it hath to require the personal service of every man able to bear arms in the case of a sudden invasion or formidable insurrection. The right in both cases is founded on one and the same principle, the necessity of the case in order to the preservation of the whole. ${ }^{180}$ (italics supplied)

Foster also referred, later in his judgment, to:

A general immemorial usage not inconsistent with any statute, especially if it be the result of evident necessity and which tended to the public safety, is I apprehend, part of the common law of England. ${ }^{181}$

Thus, in the case of service in the army, Foster asserted that, in war time, ${ }^{182}$ there was:

- a Crown prerogative to require any able-bodied male subject (he mentioned no age restriction) to undertake compulsory military service in the case of: (a) sudden invasion: or (b) formidable insurrection (i.e. civil war);

- the basis for this contention by Foster was not any Act of Parliament as such. ${ }^{183}$ Nor any case. But a Roman legal concept of 'lex salus' (the safety of the people, which Foster called 'public safety').

However, when had (and has) lex salus ever been accepted in legal decisions as a fundamental principle of English law? It is asserted Foster was mistaken. There was no Crown prerogative to impose compulsory military service on all able-bodied males in the case of war - whether externally or internally begotten - which is why, for 700 or so years after the Norman Conquest (1066) there has been no prior case.

\section{(f) Broadfoot (1743) - Irrelevant Permanent Legislation}

Leaving aside temporary legislation (now repealed) which Foster accepted was irrelevant (because it was legislation and not the direct exercise of a Crown prerogative) his judgment did not expressly refer by name to permanent Acts which might support any Crown prerogative to conscript (save for an Act of 1641 considered below, see (g)). However, a casenote to Broadfoot (1743) by his nephew (Dodson) who edited the $2^{\text {nd }}$ edition of his work (in 1776) ${ }^{184}$ stated:

This personal service in cases of extreme necessity [i.e. lex salus] is a principal branch of the allegiance every subject owes to the Crown (italics and underlining supplied).

This casenote statement bases an asserted Crown prerogative on the tenurial obligation of allegiance, which is not the same as the ultimate safety of the people (lex situs). These are quite different things and - in any case - all military tenurial obligations were abolished in 1660 (apart from ceremonial ones of grand and petty sarjeanty). It is unfortunate that Dodson made this statement since Foster did not base any argument on such in his judgment. Dodson, in his casenote, also referred an Act of 1495 which is still extant, being 11 Hen VII (1495) c 1 (An Act that no person going with the kings to the wars shall be attaint of treason), the preamble to which stated:

The king our sovereign lord calling to his remembrance the duty of allegiance of his subjects of this his realm, and that they by reason of the same are bound to serve the prince [i.e. the king] and sovereign lord for the time being in the wars for the defence of him and the [his] lands against every rebellion power and might reared against him, and with him to enter and abide [remain] in service in battle if the case so require..

However, this preamble was in the context of subjects fighting for what later turned out to be a de facto (and not a de jure) sovereign. This Act provides that they are not to be held guilty of treason under the Treason Act 1351 if they so do. Thus, the allegiance referred to was only in the context of the Treason 1351 (and has always been cited as such) and so, with good reason, Foster did not cite this Act - which is obsolete in any case. ${ }^{185}$

In conclusion, Foster - when reviewing material to support his contention - did not cite an Act of 1495 (relating to the Treason Act 1351) and correctly so.

\footnotetext{
${ }^{180}$ Foster, n 162, p 158.

${ }^{181}$ Ibid, p 159. Is this true? Surely, he meant any 'lawful usage'. An unlawful custom is not part of the common law.

${ }^{182}$ Foster was thinking of a war time situation only since he later stated, n 162, p 159, "War itself is a great evil, but it is chosen to avoid a greater. The practice of pressing is one of the mischiefs war bringeth with it.' He was not thinking of compulsory military service in peace time.

${ }^{183}$ Foster gave judgment in 1743 before Pitt's Militia Act of 1757, s 45 in which the shire militia could be embodied to deal with any invasion (actual or or threatened) or rebellion in any part of the realm.

${ }^{184}$ The $1^{\text {st }}$ edition of Foster's work was in 1762. Foster died in 1763. The $2^{\text {nd }}$ ed. was issued in 1766 and a 3rd in 1809 , by his nephew (Dodson) who provided fns to the case. However, Dodson failed to refer to Pitt's Militia Act 1757 which was remiss, since it made Foster's judgment redundant.

${ }^{185}$ Obsolete because, since the Bill of Rights 1688, Parliament has designated the sovereign (being the issue of Princess Sophia, i.e. George I and successors). Thus, any one levying war against the same commits high treason. The 1495 Act appears never to have been invoked anyway.
} 


\section{(g) Broadfoot (1743) - Relevant Permanent Legislation}

The casenote of Dodson in Broadfoot (1743) also referred to two other pieces of legislation (now repealed) which Foster almost certainly did take in account when formulating this contention as to the Crown being able to impose compulsory military service:

- $\quad$ Act of 1327. 1 Edw III (1327) st 2 c 5. ('None shall be compelled to go to war out of the shire where he dwelleth, but where necessity requireth'). The case note of Dodson also referred to this Act although Foster did not refer to it expressly in his judgment. This Act states:

The king wills that no man from henceforth shall be charged to arm himself, otherwise than he was wont in the time of his progenitors [i.e. ancestors] kings of England; ${ }^{186}$ and that

none be compelled to go out of his shire, but [where necessity requireth and sudden coming] of strange [foreign] enemies into the realm;

and then it shall be done as hath been used in times past for the defence of the realm. ${ }^{187}$ (wording divided for ease of reference and underlining supplied)

- $\quad$ Act of 1641. 17 Car $1 \mathrm{c} 28$ (1640). (An Act for the better raising and levying of soldiers for the present defence of the kingdoms of England and Ireland). Foster noted that this Act, in its preamble, stated:

by law no man is compellable to go out of his county to serve as a soldier, except in case of necessity of sudden coming of strange enemies into the kingdom, ${ }^{188}$ or except he was bound thereto by tenure [ie. by tenurial service]. ${ }^{189}$ (wording divided for ease of reference and underlining supplied).

The preamble to the Act of 1641 is only relevant to the extent that it refers to the Act of 1327 and it need not be further considered at this juncture. As for the judgment of Foster and his statement:

I think the Crown hath a right... to require the personal service of every man able to bear arms in the case of a sudden invasion or formidable insurrection, ${ }^{190}$

it seems clear his wording was based on the Act of 1327 . However, Foster mis-stated it. The Act of 1327 indicated that no shire militia soldier could be compelled to leave his county to serve - apart from in the case of a foreign invasion (as the Act of 1641 makes clear) or tenurial service (abolished in 1660). However, Foster made up his own version. One completely different viz:

- that the Crown (regardless of the Act of 1327) could impose compulsory military service on any able- bodied subject in the case of: (a) foreign invasion; OR (b) formidable insurrection. Yet, the Act of 1327 never said (b) !

- also, this Act of 1327 dealt only with commissions of array (the shire armies, later, called the local militia) and not to any national army since there was no standing army until 1689) and Foster knew this. ${ }^{191}$

The age requirement for these commissions of array was 15-60 (up from 12 in 1195) for able-bodied male subjects. It did not apply to all able-bodied men (nor to clerics). And:

- the Act of 1327 imposed only a requirement to bear (that is, to display the military weapons they were required to have) in a general muster (i.e. to appear in array (marshalled) before the sheriff (the shire reeve)) bearing the weapons required by the Assize at Arms 1181 (as modernised by the Stature of Westminster 1285);

- $\quad$ it did not refer to those chosen (elected) ${ }^{192}$ from this general muster by the sheriffs to actually fight. Those chosen were only the best fighters and, therefore, far fewer than all the able-bodied men in that shire. Greatly so, since it was so costly to send men to war. Thus, even from early times they only chose the best fighters.

\section{(h) Problem with Foster's judgment in Broadfoot (1743)}

Foster's formulation was based on a mis-quote of the Act of 1327 . He extrapolated it to refer to civil war ('formidable insurrection'). Also, Foster did not make it clear that the Act of 1327 only applied to the shire militia

\footnotetext{
${ }^{186}$ As will be later seen, this refers to the obligation of subjects to arm themselves with military weapons (to 'bear arms') under the Assize of Arms 1181 (and the Statute of Westminster 1285). This obligation was abolished in 1603 about which Foster would have known. Thus, it was irrelevant to his judgment in 1743 .

${ }^{187}$ See also McBain, n 43, p 54. For a more modern translation see Stephenson, n 150, p 223. In particular, "no shall be distrained to go outside his county except in the case of necessity owing to the sudden invasion of enemy aliens into the kingdom'. 'Distrained' means compelled or forced.

${ }^{188}$ This is a direct reference to the Act of 1327.

${ }^{189}$ This refers to military tenurial service which was abolished in 1660, about which Foster would have known. Thus, it was irrelevant to his judgment in 1743. See for slightly different wording, Gardiner, n 172, p 243,

${ }^{190}$ See n 162.

${ }^{191}$ Foster, n 162, p 175 was clearly referring to this Act of 1327 (though he did not cite it as such) when he referred to 'commissions of array'.

192 This is the meaning of the Act 18 Edw III st 2 c 7 (When soldiers wages shall begin) cited by Foster, n 161, p 165 'Men of arms, hoblers and archers, chosen [i.e. elected, selected] to go in the king's service out of England, shall be at the king's wages from the day that they depart out of the counties where they were chosen till their return.' It was enforced by 25 Edw 3 st 5 c 8 (1351) and confirmed by 4 Hen 4 c 13. Likely, this Act also answers the question of Foster, n 161, pp 160-1, in respect of the navy (that is, an impressed mariner was paid from date of service, not from when chosen (seized)).
} 
and not to any professional army (in his time, in 1743, there was a separate professional army in existence, one from 1689 regulated by annual Mutiny Acts). Further, Foster appears to have also forgotten an Act of $1662 .{ }^{193}$ This Act put the operation of the shire militia on a wholly statutory basis. In particular, s 1 provided for them to be deployed in England, Wales and Berwick on Tweed (but not abroad, including Scotland and Ireland) in the event of any:

\section{Insurrection [,] rebellion or [foreign] invasion}

Thus, this Act of 1662 superceded the Acts of 1327 and 1641 referred to above. It also superceded any Crown prerogative in respect of the militia. And, it certainly did not provide for any common law 'lex salus' deriving from immemorial custom (further, to the extent there was such, this Act superceded it).

- In short, the only Act that Foster need have cited in his judgment was this 1662 Act. However, the same excluded any Crown prerogative being asserted since this Act repealed it;

- Further, the 1662 Act only related to the shire militia (which was in, 1743, a form of territorial army One which was, effectively, voluntary). ${ }^{194}$ It did not apply to the professional army of his time which was governed by Mutiny Acts, which Acts expressly did not cover the militia.

Therefore, it is asserted, there was a complete disparity between the relevant legislation (the 1662 Act) and Foster's formulation. Thus:

- $\quad \mathbf{1 6 6 2}$ Act. The shire militia can be deployed to serve anywhere in England (but not abroad) in the case of: (a) foreign invasion; or (b) and insurrection (i.e. uprising); or (c) rebellion (civil war);

- $\quad$ Foster. The Crown can compulsorily levy for military service all able bodied male subjects (it seems of whatever age) in the case of: (a) foreign invasion; or (b) formidable insurrection (i.e. uprising). The basis for this contention was the 'lex salus'.

As it is, there may have been an ulterior motive for Foster's opinion (which was only obiter anyway). It was to suggest to Parliament that they needed to pass an Act since there was a major lacuna in the law. Foster would also have been aware of the difficult situation in 1743 when he gave judgment. There was a threat of a Jacobite rising (which occurred in 1745) and yet the shire militias were inept and the system of allowing substitutes had transformed them into little more than class-controlled clubs. Therefore, one wonders whether Foster's obiter comments in respect of the army - and his deliberate inclusion of reference to 'formidable insurrection' - were to help the Crown argue that the shire militias could be used for service in Scotland. In fact, this was achieved by Pitt's Militia Act 1757 which made Foster's judgment in 1743 redundant. This Act, s 45 stated:

in case of actual [foreign] invasion, or upon imminent danger thereof, or in the case of rebellion, it may and shall lawful for $[\mathrm{HM}]$ to...direct his [lords] lieutenant...to draw out and embody all the...militia of their respective counties...for the suppression of such invasions and rebellions. (italics)

Thus, had Foster been giving judgment after this Act of 1757 (and not in 1743) he would have simply referred to this Act 1757, which - like the Act of 1662 - superceded any Crown prerogative in the matter. This point was overlooked by Halsbury in 1907. Probably, because Foster had not cited (or had overlooked) the Act of 1662.

As it is, Robertson summarised the background to Pitt's Militia Act 1757:

The War of the Austrian Succession, ${ }^{195}$ and more particularly the disasters of the years $1755-1757,{ }^{196}$ have proved the desirability of re-organizing the military forces, and constituting a really effective fighting force for home defence, so as to have the regular army free for operations outside Great Britain. The machinery [of the 1757 Act] abandoned the principles of the general levy [i.e. shire militias] and the machinery by which property owners furnished horses, arms, and men on a graduated scale which had been prescribed in the Militia Acts of Charles II (see 15(t))...Pitt's policy was to maintain and extend Parliamentary control, but utilize the territorial influence of the county ${ }^{197}$...His Bill [which was to later become the 1757 Act] was severely criticised in both Houses - on the usual ground that it would militarise the nation and endanger the liberty of the subject; curiously enough, also, because it encroached on the prerogative of the Crown. ${ }^{198}$

Be that as it may, Foster developed his contention that the Crown could conscript men to fight in the army in the case of 'sudden invasion or formidable insurrection' even though he knew that the Act of 1327 from which his wording was borrowed did not say that (it only referred to foreign invasion). And, that it only applied to the shire

\footnotetext{
${ }^{193}$ See also 15(t).

194 There were voluntary since, like knight service and scutage, a person could buy themselves out of active service, by paying for another to take their place.

195 This was between 1740-8 and resulted in the rise of Russia.

${ }^{196}$ See the Seven Years War between Britain and France.

${ }^{197}$ CG Robertson, Select Cases and Documents to illustrate English Constitutional History 1660-1832 (1935), pp 230-1. As to Pitt's policy 'The force was to be raised through and from the parishes, offered by the county landowners and governed by the county lieutenant - a national force based on a parochial and county framework... The power of the Crown to appoint officers [to the shire miltias] was reduced to a veto on appointment and the right of dismissal.'

198 Ibid.
} 
army - and not to the professional army which had existed since 1689 as a standing army (pursuant to annual Mutiny Acts) of which he would have been aware, such that he accepted the only (legal basis) for conscription in the army which was not legislative but by virtue of asserting a Crown prerogative, was 'lex salus'. However, he would have known the latter was never a principle of the English common law or legislation. As it is, Foster's judgment was rendered redundant in 1757 since Pitt's Militia Act expressly indicated when the shire militias were obliged to fight out of their shires.

In conclusion, it is asserted that Foster's judgment - obiter in so far as it dealt with any prerogative of the Crown to conscript men for the army - must be treated with great circumspection since legislation of 1662 (and 1757) dealt comprehensively with the shire militia and provided for no 'lex salus.' As for the general army, this had been created and regulated by legislation since the Mutiny Act 1689 - $s$ of which made it express that the Mutiny Act did not extend to the shire militia. Bearing these caveats in respect of Halsbury and Foster in mind, was there ever a common law Crown prerogative to compel all able bodied men to serve in the army, as Halsbury suggests? This will now be considered.

\section{(i) Anglo-Saxon Law (Dooms)}

The Romans left Britain c. 410 AD. The Anglo-Saxons then arrived (mainly from north Germany). ${ }^{199}$ The Saxons had a system of compulsory service for three things. It was called the trinoda necessitas (the 'three obligations' or legal requirements). Blackstone, writing in 1765 stated:

all lands were formerly subject to a tax, for the building of castles wherever the king thought proper. This was one of the three things, from contributing to the performance of which no lands were exempted; and therefore called by our Saxon ancestors the trinoda necessitas: sic [that is] pontis reparatio, arcis constructio, et expeditio contra hostem. $^{200}$

Elsewhere in his work, Blackstone referred to the:

trinoda necessitas, of repairing the highways, building castles, and repelling invasions... ${ }^{201}$

This wording is not very felicitous since a better translation would be: 'the three legal obligations [imposed on a freeman] to repair the highways, to repair military fortifications and to perform military service' (i.e. to campaign against the enemy). As it is, in Anglo-Saxon times the obligation to perform military service was (likely) imposed only on freemen. Not on slaves, serfs (for good reason) or women. ${ }^{202}$ As to the age, Chalmers (in 1922) stated:

Prior to the Conquest [1066] all freemen between fifteen and sixty who were capable of bearing arms had to serve in the $f y r d{ }^{203}$ or general levy [militia], and those who evaded service had to pay a fyrd-wite, a penalty which might extend to entire forfeiture of land. There was a levy for each county, presided over by the earldorman or earl. ${ }^{204}$

The reference to freemen between 15-60 seems inaccurate. More likely, the minimum age was $12 .{ }^{205}$ And most men would have been dead by 60 (average life expectancy was in the 30s). Thus, the upper age (in practice) was (likely) 40 or less. Since the Anglo-Saxon kings had no foreign possessions (and an insufficient tax base to expand abroad) there would have been no obligation to undertake military service outside England. Walker (writing in 1980) stated:

- $\quad$ Fyrd. The English militia during the Anglo-Saxon period. The ealdorman of the shire was probably charged with calling out and leading the fyrd. It was probably composed of all freeholders. It was gradually superceded by the gathering of the thanes and their retainers, but seems to have been called occasionally even after the Norman Conquest [1066]. ${ }^{206}$

\footnotetext{
${ }^{199}$ For a useful potted history see Plucknett, n 16, ch 1.

${ }^{200}$ Blackstone, n 27, vol 1, p 255. See also vol 2, p 102. Plucknett, n 16, p 9 'trinoda necessitas or liability to military service and to a contribution for the repair of fortresses and bridges (fyrd-fare, burh-bot, and brycg-bot).' Ibid, $\mathrm{p} 35$ 'The triple burden was service in the fyrd, repair of bridges, and repair of fortresses, and the crown insisted that no one was exempt (in fact, only one genuine exemption is known).' ${ }^{201}$ Ibid, vol 2, p 102.

${ }^{202}$ Allowing serfs to be armed could have resulted in challenge to the established order - as was later found to be the case in the Peasant's Revolt of 1381.

${ }^{203}$ The word, also spelt 'fierd' or 'fyrde', was (it seems) a foreshortening of 'fyrderinga'. J Wishaw, A New Law Dictionary (1829)(fyrderinga) 'from the Sax[on], friderung, (i.e. expeditionis apparatus) a going out to war, or a military expedition at the king's command; not going upon which when summoned was punished by a fine at the king's pleasure'. See also 'fyrthing, or fyrdung, a military expedition.'

${ }^{204}$ Chalmers, $\mathrm{n} 11, \mathrm{p} 142$. He continued 'The general levy was a civil as well as a military force, and in its civil capacity it was used to suppress riots and known as the sheriff's posse comitatus.' The posse was used to seize those suspected of crimes. They were assembled by the cry of 'haro' ('harrow' or 'help'). See DM Walker, The Oxford Companion to Law (1980) (haro, clamour de). Also, (hue and cry).

${ }^{205}$ Chalmers failed to cite the Laws of Canute (1016-35) which refer to those aged 12, see AJ Robertson, The Laws of the Kings of England from Edmund to Henry I (1925), p 185. See also GS McBain, False Imprisonment and Refusing to Assist a Police Officer (2015) Journal of Politics and Law, vol 8, no 3, p 60 (12 was the age for giving frank pledge which is unlikely to have been different). Chalmers may have taken the upper age from Coke, n 25, vol 2, p 592 commenting on the Act De Militibus c. 1307. It sounds too high for Anglo-Saxon times.

${ }^{206}$ Walker, n 204 (fyrd).
} 
Anglo-Saxon law - the first of which extant is from AD 616 - refers to the trinoda necessitas - in various pieces of legislation (called dooms). Thus, the laws of king Ine (c. 694) referred to neglect of military service. ${ }^{207}$ Feilden summarised the history of the army in Anglo-Saxon times:

In Anglo-Saxon times the trinoda necessitas made service in the fyrd, or national militia [army], incumbent on every freeman. Such service was a personal obligation and dated from the time when 'the host was the people in arms'208 and military organisation was largely dependent on tribal and family relations. The fyrd was an infantry force, led to battle by the ealdorman, and all who failed to comply with the summons to its ranks were liable to a heavy fine called fyrdwite. The importance of the fyrd was considerably lessened by the development of the comitatus into a body of professional warriors, but its decline was arrested by the Danish [Viking] wars of the $9^{\text {th }}$ century. But though the national levies fought gallantly enough when well led, it was soon obvious that they were no match for the Dane. They could not be called out without the consent of the local folkmoot, ${ }^{209}$ and when they appeared in the field they found themselves outmatched at all points...It was clear that the Vikings could only be successfully opposed by professional troops, and Alfred turned to the thegnhood [thanehood, nobles] to supply him with the basis of a new military organisation. At the same time he reformed the fyrd by dividing it into two halves, each of which took the field in turn, while the other was employed in defending the burghs. ${ }^{210}$

Thus, while there was a general legal obligation on all able-bodied freemen of a certain age to provide military service, there was not a standing army. Further, it seems clear that men could buy themselves out of their military obligation by paying a fixed sum. ${ }^{211}$ Also, foreign mercenaries were used. ${ }^{212}$ Finally, the sovereign (and great nobles) had their own professional bodyguards (housecarles) who comprised hardened warriors. ${ }^{213}$

Thus, while there was military service obligation imposed on all able-bodied men (aged, from 12 years old), in practice, such was not employed. Not least, because the country would starve (through no men to tend the fields) and be defenceless. As a result, in practice, military service was performed in those times by the following:

- $\quad$ military bodyguards (housecarles);

- thegns (i.e. nobles, with their retainers);

- foreign mercenaries;

- $\quad$ shire militias (but only selected men).

In conclusion, there was compulsory military service for able bodied men over the age of 12 (and they could be fined for not performing it). However, in practice, fighting was undertaken by mercenaries on a voluntary basis for which they were paid. And, in the case of the fryd, men could buy themselves out of miliary service albeit, the extent is not known.

(j) Post-Conquest - Up to 1113

After 1066, many things changed. A major change was to the military system. William I (1066-87) claimed title to all land in England. He, then parcelled out a lot of the same to c. 1500 tenants-in-chief. They, then, created c.

\footnotetext{
${ }^{207}$ FL Attenborough, The Laws of the Earliest English Kings (1963), p 53 'If a nobleman [thegn, thane] who holds land neglects military service, he shall pay 120 shillings and forfeit his land; a nobleman who holds no land shall pay 60 shillings; a commoner [ceorl] shall pay a fine of 30 shillings for neglecting military service.' See also: (a) Laws of King Aethelred (c 1008), Ibid, p 87 'the duties of military service shall always be diligently attended to...'; (b) Laws of King Canute (c. 1018): Ibid, p 207 'If anyone neglects...military service, he shall pay 120 shillings as compensation to the king in districts under English law etc.' See also W Stubbs, The Constitutional History of England (4 $4^{\text {th }}$ ed, 1883), vol 1, pp $82 \& 209$.

${ }^{208}$ See Stubbs, n 207, p 208 'The host was originally the people in arms...'.

${ }^{209}$ This is important. Even in Anglo-Saxon times, the shire armies could not go to war when ordered by their king without the consent of their shire community, the footmoot [folk assembly] - the precursor to the national assembly of Parliament in later times.

${ }^{210}$ Feilden, n 10, pp 305-6. Also, DJV Fisher, The Anglo-Saxon Age c 400-1042 (1973), p 264 and F Stenton, Anglo-Saxon England ( $3^{\text {rd }}$ ed, 1971), p 291.

${ }^{211}$ Stubbs, $\mathrm{n} 207$, p 131 'The military contingents of the shire were also made a matter of composition... Whether these...were, as in the case of the churches, a matter of privilege, can scarcely be determined in the almost entire deficiency of secular charters before the Norman Conquest [1066]. It is however probable from Domesday [1086] that long before that event the shires had been allowed to acquit themselves of several of these duties by paying fixed sums or furnishing fixed contingents...'. See also Fisher, n 210, pp 263-4. Also, Domesday Book (1086) note of Berkshire custom (for example), Stephenson, n 150, p 45 'If the king sent an army anywhere, only one soldier went from five hides, and $4 \mathrm{~s}$ was given him from each hide as food and pay for two months. This money... was not sent to the king, but was given to the soldiers. If any one was summoned for an expedition [military service] and did not go, he forfeited all his land to the king. But if any one, for the sake of remaining [at home], promised to send another in his place, and yet he remained who was to have been sent, his lord was quit [released from punishment] through [payment of] 50s.'

${ }^{212}$ Fisher, n 210, p 309 'In 1012 [king] Aethelred (978-1013, 1014-6] took Thorkell the Tall [c. 950s - after 1023] with his forty-five ships and their crews into his pay, and mercenary troops returned to England with him in 1014. Henceforth stipendiary soldiers were always an element in the royal army.'

${ }^{213}$ Stenton, n 210, p 582 'For the defence of the realm by land the king could bring into the field a composite force, in which a nucleus of professional soldiers was combined with an aristocractic element drawn from the thegnhood of the shires, and with peasant levies of varying quality. The kernel of the host was composed of the military retainers - the housecarles - of the king and other magnates.'
} 
8000 under-tenants who, then, did the same. ${ }^{214}$ The obligations for all this landholding was that the tenant held the land subject to:

(a) allegiance;

(b) tenurial service obligations.

In the case of the 1500 tenants-in-chief (tenants in capite) their allegiance was directly to the Crown. In the case of the others, they owned homage or fealty to their superior (mesne) tenant. However, they also owed an overriding allegiance to the sovereign as the lord paramount. The vestiges of this system still survive. ${ }^{215}$ Plucknett stated it thus:

Prior to the conquest all lands had been subject to the trinoda necessitas. This obligation still continued. But after the feudal system of tenure had been fully established, all lands were held subject to certain additional obligations, which were due either to the king (not as sovereign, but as feudal lord) from the original grantees as tenants-in-chief (tenentes in capite), or to the tenants-in-chief themselves from their under-tenants, or to mesne tenants from their own under-tenants. Of these obligations the most important was that of knight's service. This was the tenure by which the king granted out fiefs to his followers, who in turn provided him with a certain number of knights properly armed and accoutred to serve in the army for forty days in the year at their own expense (servitium debitum). The lands of the bishops and dignified ecclesiastics, and of religious foundations, were also generally held by this tenure. Sometimes, however, religious bodies and ecclesiastics in right of their churches held land by a tenure known as frankalmoign, or free alms; they rendered no earthly service to the lord, but an indefinite spiritual service, prayers for the soul of the donor. ${ }^{216}$

In the case of Anglo-Saxon law, it seems that - at least, for a time - the trinoda necessitas continued. Thus, the socalled Laws of Henry I (1100-35) c.1113 refers to certain Crown prerogatives (de iure regis) ${ }^{217}$ stating:

These are the jurisdictional rights which the king of England has in his land solely and over all men, reserved through a proper ordering of peace and security...failure to perform fird fare [fyrd fare $].{ }^{218}$ Also: Anyone who fails to perform... fird fare, shall forfeit one hundred and twenty shillings, ${ }^{219}$ or fourteen compurgators shall be nominated for him and he shall select eleven of them in order to deny the charge. ${ }^{220}$

Thus, from the Norman times, there was, in military terms:

(a) knight service based on allegiance; and

(b) the older Anglo-Saxon formed shire militias.

However, (a) was supplemented by William I (1066-87) by a wider obligation. ${ }^{221}$ The Revised Articles of William I (Willelmi Articuli Retractati). ${ }^{222}$ stated:

We have likewise decreed that all free men...shall affirm that in and out of the whole kingdom of England...they will be loyal to king William their lord [1066-87], and everywhere along with him uphold their lands and honours... and defend them against enemies and aliens [i.e. foreigners].

This may be origin of allegiance to the sovereign as lord paramount, which prevailed over any other allegiance and it may be the source of any wide obligation as stated by Halsbury in 1907. However, the problem is that it is unclear whether the Revised Articles of William I (1066-87) - or the Laws of William I - were ever authentic

\footnotetext{
${ }^{214}$ Lord Brougham, The British Constitution (1861), p 148 'the whole country [England] was divided into knights' fees, the whole landowners, as well clerical as lay, being obliged to send for each fee, that is each five hides, or 600 acres of land, a knight equipped for the field to serve during forty days. This raised a body of 60,000 horse, there being 60, 215 knights' fees, whereof 20,015 were in the hands of the clergy.'

${ }^{215}$ See GS McBain, Modernising English Land Law - Part 2 [2019] ILR, vol 8, no 1, pp 85-131.

${ }^{216}$ Plucknett, n 16, p 35 and see generally ch 2. See also Walker, n 204 (knight-service).

${ }^{217}$ LJ Downer (ed), Leges Henrici Primi (1972), p 109. Downer translates 'de jure regis' as 'concerning the royal jurisdiction'. A better translation might be 'of the law relating to the king'. That is, the law concerning (stating) the Crown's prerogatives.

${ }^{218}$ Ibid. Downer noted, p 326 ' fird fare [i.e. army service] This is the obligation to serve in the army. It is described as fyrdinga'. Ibid, p 325

' The penalty for [neglect of] this is fyrd wite...'. See also n 204.

${ }^{219}$ This seems to refer to the laws of king Ine, see $\mathrm{n} 207$.

${ }^{220}$ Downer, $\mathrm{n} 217$, p 119. It seems, however, that, by 1290, a person could avoid the obligation of military service. See the first English law dictionary, Termes de la Ley (last ed, 1721 rep Law Book Exchange), 'Ferd fare is to be quit from going to the war', referring to Fleta (c. 1290), vol 1, c 47. See also Davis, n 53 (passim, charters).

${ }^{221}$ This was on top of any knight service owed. For an example of a summons for knight service, see Stephenson, n 150, pp 58-9 viz. William I (1066-87) to the abbot of Evesham (in 1072) 'I command you to summon all those who are under your charge and administration that they shall have ready before me at Clarendon on [ ] all the knights that they owe me. Come to me likewise yourself, on that day, and bring ready with you those five knights that you owe me from your abbey.' See also W Stubbs, Select Charters ( $9^{\text {th }}$ ed, 1966) pp 96-7 (Writ of Summons to the Feudal Host).

${ }^{222}$ See Robertson, $\mathrm{n} 205, \mathrm{p} 245$. The preamble is 'The decrees and legal reforms of our lord king William the Bastard [1066-87], which he established in England, formerly called Britain.' This revision may have been one to so-called '10 Articles of William I' (c. 1192). Ibid, pp 238-43, art 2 of which states 'We have also ordained that by covenant and oath every freeman shall promise within and without England to be faithful to king William [1066-87], with him and before him to keep and defend his lands and his honour with all fealty against his foes. See also Stephenson, n 150, p 36.
} 
legislation. ${ }^{223}$ Further, given its date (before the time of legal memory, 1189) they never appear to have been taken as such in later times.

In conclusion, an obligation on those who owed knight service to fight for the sovereign and to defend him against his enemies and aliens would have arisen by way of tenurial military service after 1066 (this ended by 1660). Further, there may have been Norman legislation (a decree) providing for general allegiance to the sovereign as lord paramount (which prevailed over any other allegiance). Yet, any such decree would not be taken to be legally binding today.

\section{(k) $\underline{\text { Post-Conquest - Scutage (1159) }}$}

For how long did the Anglo-Saxon military service (fyrd fare) last into Norman times? This is unclear. ${ }^{224}$ Feilden stated:

Toward the close of the Anglo-Saxon period, the organisation on which the fyrd had been based was falling into abeyance. Domesday [1086] shows us that towns and even shires were allowed to compound for their service due from individual inhabitants... But the fyrd was retained by the Conqueror [William I, 1066-87] as a useful weapon against the baronage, and at the celebrated gemot [assembly] at Salisbury (1086) all landowners, whether tenants in chief or not, were required to take an oath of allegiance to the king. The fyrd did good service against the disaffected Normans in the reigns of Rufus [king Rufus, 1087-1100] and Henry I [1100-35] and under Stephen [1135-54] and Henry II [1154-89] beat the Scots at Northallerton in 1138 and Alnwick in 1174. As a rule it was not called upon for foreign service, ${ }^{225}$ but in 1094 Rufus ordered 20,000 of the national militia to be sent to Normandy: on their arrival at Hastings, Ranulf Flambard seized the journey money of ten shillings per man which their shires had furnished them and sent them penniless home. ${ }^{226}$

The tenurial military obligation of knights service (see $(\mathbf{j})$ ) began to become undermined by subjects being able to avoid it by paying money in lieu. Thus, a tenant-in-chief could pay a fine, to avoid the obligation to do military service in person. ${ }^{227}$ And, from 1127 (at least), tenants-in-chief could buy themselves out of their tenurial obligation (to provide the sovereign with a certain number of knights properly armed and accoutred to serve in the army for 40 days in the year at their own expense). Thus, they could pay shield money instead, called escuage (scutage). ${ }^{228}$ Walker stated:

Scutage or Escuage (from latin scutum, a shield). Shield money, in medieval feudal law, a payment in lieu of military service, paid by a tenant-in-chief in respect of the service of knights which he owed to the Crown. His personal obligation to serve could not be discharged by scutage but only by fine. Payment of scutage, though known in France and Germany, was most highly developed in England when it became a general tax on knights' estates at rates which by the thirteenth century were standardised. King John [1199-1216] demanded frequent and heavy scutages and Magna Carta [1197] forbade the levying of scutage without the consent of a general council. Scutage was divided between the king and the tenants-in-chief who gave personal service in the campaign. It became obsolete by the fourteenth century. 229

Why was scutage permitted? The Normans recognised the paramount need - in changing warfare - for a professional army. They did not want (or need) a huge number of poorly armed English freemen to fight their battles. ${ }^{230}$

\footnotetext{
223 They could be a later medieval forgery.

${ }^{224}$ Walker, n 204 (fyrd) 'The English militia [army] during the Anglo-Saxon period. The ealdorman of the shire was probably charged with calling out and leading the fyrd. It was probably composed of all freeholders. It was gradually superseded by the gathering of the thegns and their retainers, but seems to have been called occasionally even after the Norman Conquest.'

${ }^{225}$ It is not clear whether the fyrd performed any military service abroad at that time.

${ }^{226}$ Feilden, n 10, p 306.

${ }^{227}$ It may well have been that the idea for compounding for military service for money taken was borrowed from Anglo-Saxon times, see $\mathrm{n}$ 204

${ }^{228}$ Wade, n 12, p 317 'actual service was commuted for a money payment (scutage).' Maitland noted, n 9, p 275 that 'Traces of scutage have been found as early as the reign of Henry I', [1100-35]. Stephenson, n 150, p 59 (cites a grant of 1127 referring to scutage). For a useful discussion of scutage in F Pollock \& FW Maitland, The History of English Law (CUP, 2 ${ }^{\text {nd }}$ ed, ed SFC Milsom, 1968) ('P\&M'), vol 1, pp 26776.

${ }^{229}$ Walker, n 204 (scutage). The last time scutage was levied was 1315. Thus, knight service was, effectively, obsolete by then.

${ }^{230}$ Foreign hired mercenaries (freebooters) were better, being professional soldiers. Thus, English barons tended to prefer them (they were more efficient and there were no problems of conflicting allegiance). JEA Jolliffe, The Constitutional History of Medieval England (1948), p 161 'Ralf Guader [pre-1042- c 1096, Earl of East Anglia, Norfolk and Suffolk] intended to hire a Danish force, Robert of Gloucester won the battle of Lincoln with Welsh (foreign) mercenaries, and in 1173 Leicester, Mowbray, and Norfolk fought with armies of hired Flemings. The amercements in the Pipe Roll of 1175 and 1176 reveal almost no trace of any English following.' Stubbs, n 221, pp 181-2 'the system of fighting by mercenaries which was adopted by William the Conqueror [1066-87] and the Norman kings on account of the insufficiency of the feudal levies. The hatred of the English towards [foreign] mercenaries reached a climax in the time of Stephen [1135-54], and Henry II [115489] only ventured on one occasion to introduce his Brabancons [hired killers from Brabant, see battle of Bouvines 1214] into the country, after the expulsion of the Flemings'.
} 
- It was for this reason that Henry I (1100-35) permitted scutage, to enable him to raise funds to hire mercenaries. ${ }^{231}$

- Further, the Normans had no intention of arming a vast number of the English common people since the Norman Conquest was bitterly opposed by them during the reign of William I (1066-87) and later. Indeed, there was a special fine imposed (murdrum) for the secret killing of Frenchmen - which suggests that this 'guerilla warfare' went on a lot during the reigns of William I and William II (William Rufus, 1087-1100).

Thus, tenurial military service began to decline from the $13^{\text {th }}$ century as knights bought themselves out, by paying scutage. This was not the only problem. Those knights who served were beginning to assert that, their tenurial military obligation being based on grants of land in England, they had no obligation to undertake military service abroad. This was first successfully vented in 1198. Plucknett noted:

A more important and successful stand [against taxation] was made in the same year by the bishops Hugh of Lincoln and Herbert of Salisbury. In a council of the barons summoned at Oxford by the justiciar, Archbishop Hubert Walter, to consider the king's [i.e. Richard I's, 1189-99] demand for an aid of [300] knights, each to receive [3] shillings a day, and to serve with him for a year against Philip of France, the two bishops alone had the courage to refuse; alleging that the lands of their sees were liable for military service within the kingdom only and not abroad. The opposition was successful; the king's demand was withdrawn; and shortly afterwards the justiciar resigned. ${ }^{232}$

The same happened under King John (1199-1216). ${ }^{233}$

In conclusion, tenurial military service began to decline from the early $13^{\text {th }}$ century as knights bought themselves out, by paying scutage. This left sovereigns employing foreign mercenaries which - by the early thirteenth century was bitterly resented ${ }^{234}$ - or relying on the shire militias.

\section{(l) Assize of Arms 1181}

As for the shire militias, Feilden stated:

The unpopularity of his mercenary troops, and the fidelity of the English militia during the rebellion of 1174 induced Henry II [1154-89] to reorganise the fyrd by the Assize of Arms (1181). All freemen except the greater barons, the Jews, and the villeins [serfs] were to arm themselves in proportion to their wealth, and their liability was to be declared by a jury before the itinerant justices. In 1205, 1217 and 1231 writs were issued for the levy of the fyrd, and the Assize of Arms was confirmed and enlarged by a writ of $1252^{235}$ and by the Statute of Winchester (1285). This Act appointed two constables in every hundred to 'hold the view of arms' and present defaulters to the justices. During the latter Plantagenet [1154-1485] reigns the military duties of the fyrd became unimportant, and it was mainly employed for police purposes. ${ }^{236}$

It is asserted that continued reference by Feilden to the Anglo-Saxon fyrd after the Assize of Arms 1181 is incorrect. ${ }^{237}$ The Assize abolished the fyrd as such - though not expressly. Rather, by means of this Assize Henry II (1154-89) substituted an Anglo-Norman system for the shire army. One:

- $\quad$ in which serfs were part of from 1252,238

- $\quad$ also introduced by him in 1181 to his continental possessions.

- which worked alongside the declining tenurial military system. ${ }^{239}$

The Assize of Arms 1181 stated, inter alia:

Whoever possesses one knight's fee shall have a shirt of mail, a helmet, a shield, and a lance: and every knight shall have as many shirts of mail, helmets, shields, and lances as he possesses knight's fees in demesne. Moreover, every freeman who possesses chattels or rents to the value of $16 \mathrm{~m}$ shall have a shirt of mail, a helmet, a shield, and a lance;

\footnotetext{
${ }^{231}$ The Normans also realised that it was vital to maintain people to cultivate the land. One poor harvest could devastate England as occurred both in the reign of William I (1066-87) and in the civil war after the death of Henry I (1100-35).

${ }^{232}$ Plucknett, n 16, p 62.

${ }^{233}$ Ibid, p 67 'The loss of Normandy [in 1204] was itself in a great measure due to the decay of feudalism, the result of Henry II's policy. [King] John [1199-1216], who was not altogether destitute of energy and courage, made some efforts to recover Normandy, but the barons, especially in the north of England, where the possessions of the new families chiefly lay, refused to follow the king, alleging that they were not bound to military service abroad.'

${ }^{234}$ Thus, Magna Carta 1215, c 51 provided 'And immediately after the restoration of peace we [i.e. king John 1199-126] will remove from the kingdom all alien knights, crossbowmen, serjeants, and mercenaries, who have come with horses and arms to the injury of the kingdom.'

${ }^{235}$ This provided for the arming of serfs (villein). Thus, it was a marked extension to the fyrd fare. See also P \& M, n 228, vol 1, pp 421-2, n. ${ }^{236}$ Feilden, n 10, pp 306-7.

${ }^{237}$ Incorrect, because Henry II (1154-89) had, with the Assize of Arms 1181 created a much more military based system, not just a group of male subjects in each shire bound to help maintain the peace (i.e. the criminal law). See also Writ for levying a force for the Defence of the Kingdom (1205), see Stubbs, n 221, p 275.

${ }^{238} \mathrm{Cf}$. The Assize of Northampton 1176, see Stephenson, n 150, p 81 'the justices shall receive oaths of fealty to the lord king [Henry II (115489]) from all who wish to dwell in the kingdom: namely, from earls, barons, knights, freeholders, and even peasants. And whoever refuses to swear fealty is to be seized as an enemy of the lord king.' However, this did not permit serfs to bear arms as such.

${ }^{239} \mathrm{P} \& \mathrm{M}, \mathrm{n} 228$, vol 1, p 276 thought that tenurial military service was (effectively) ended by 1300 due to scutage (which seems to have developed into a right), sub-infeudation and the need for professional soliders. One would agree. See also n 229 (last scutage levied 1315).
} 
and every freeman possessing chattels or rents to the value of $10 \mathrm{~m}$ shall have a hauberk, an iron cap, and a lance. Item, all burgesses and the whole community of freemen shall have [each] a gambeson [padded surcoat], an iron cap, and a lance. Besides, each of them shall swear to...be faithful to the lord king Henry [II, 1154-89]....and to bear these arms in his service according to his command and in fealty to the lord king and his kingdom. ${ }^{240}$

This Assize, specified what arms (military weapons) all able-bodied shire men ${ }^{241}$ should have available in their homes. Annually, these men were summoned to display them - assembling at a place determined by the sheriff (this display was called the 'array of arms'). However, as in Anglo-Saxon times, from this general muster of men, in each shire, only a much more select band of men chosen for battle, when required. Thus, a Writ for Assembling the Jurati ad Arma 1231 stated, for example:

The sheriff of Gloucestershire has been commanded that, notwithstanding the king's command concerning the coming of those sworn to arms and with battle-axes to the king's army, he should nevertheless cause the men to come who are sworn 'to iron', namely coat of mail as worn by a knight, hauberk and sword-proof coat. He should also cause to come to the same army only the two hundred men with two hundred axes, and with their food for 40 days which the sheriff shall cause to be provided by the men of his shire who are sworn to lesser arms, whom the king wishes to remain in their own districts. ${ }^{242}$

Thus, as in Anglo-Saxon times, from the shires, the sovereign sought to draw up a smaller, more professional, army, in this case, to supplement his tenurial knights. And, as with scutage, there was a system of compounding, in which shiremen could buy themselves out of military service. Further, the remaining males in the Assize who did not go into battle paid off their obligation to go into battle, by paying for their colleagues, as the above Writ indicates. A similar commission of array (array of arms) in 1282 stated:

The king to all his bailiffs and faithful men of the counties of Nottingham and Derby...whereas we have sent our beloved and faithful [ ] into the aforesaid counties there to select, both within and without liberties, three hundred foot soldiers from those more capable and fit to bear arms, and to lead those men to us as we shall instruct them: [therefore] we command that, when the said [ ] come to the aforesaid counties to select the said men as stated above, you are to be serviceable, helpful, attentive and obedient to him... ${ }^{243}$ (italics supplied)

\section{(m) $\underline{\text { Statute of Westminster } 1285}$}

It seems that the Assize at Arms (1181) declined over the years. Doubtless, it atrophied during years of peace and the shire men would never have objected - it must have been a nuisance. Thus, this shire army was further remodelled by the Statute of Westminster (1285). It stated, inter alia:

it is commanded, that every man have in his house harness for to keep the peace after the ancient assize; that is to say, every man between [the age of 15-60], shall be assessed and sworn to armour according to the quantity of their lands and goods... and that view of armour be made every year two times ${ }^{244}$ and in every hundred and franchise two constables $^{245}$ shall be chosen to make the view [i.e. inspection] of armour...

In short, from the $13^{\text {th }}$ century onwards, although - technically - all able bodied men in the shire between the age of 15-60 could have been summoned to battle in the shire by the sovereign, such did not happen. Not least, since the remaining population would have been left to starve (no men to gather in the crops). Also, defenceless. Thus, Stubbs noted:

the force [commission of array] would, if assembled in arms, have included the whole adult [able-bodied] male population. Such a levy was never even formally called for; it would have been quite unmanageable, would have robbed the land of its cultivators, and left the country undefended except at head-quarters. ${ }^{246}$ (italics supplied)

As for the knight service, to prop up this tenurial military obligation, the Crown required those held land above a certain value were to be 'distrained' ( a polite way of saying, to be forced) to undertake knight service. ${ }^{247}$ However,

\footnotetext{
${ }^{240}$ Stephenson, $\mathrm{n} 150, \mathrm{p} 85$.

${ }^{241}$ The lower age appears to have been raised from 12 (in Anglo-Saxon times) to 15 by a proclamation in 1195 (this being specified as the age for the posse comitatus (power of the county), see McBain, n 205, p 82 (men of 15 years or over). Ibid, p 83, n 270. Also, Stroud, n 33, (posse)(age 15). Also, Stephenson, n 150, p 139 (Ordinance for the Preservation of the Peace, 1242), p 139 (aged 15-60).

${ }^{242}$ B Wilkinson, Constitutional History of Medieval England 1216-1399 (1965), vol 3, p 222.

${ }^{243}$ Ibid, p 223.

${ }^{244}$ This may have been a relaxation since, although the posse comitatus met twice a year, it seems that the 'view of arms' (i.e. commission of array) was only held on one of these occasions.

245 These were, at first, military officers. See generally, Maitland, n 9, pp 276-7.

${ }^{246}$ Stubbs, n 207, vol 2, p 296 (citing examples from 1205-82).

${ }^{247}$ See also Wilkinson, n 242, vol 3, p 222 who cites an example of 1224. Also, p 223, a royal edict of 1256, referred to by M Paris, Chronica Majora, book 5, p 60, 'In the same year there was a royal edict, according to which it was commanded and proclaimed throughout all the realm of England that whoever had $£ 15$ worth of land and over should procure suitable arms and should be admitted to knighthood. Thus, England, like Italy, would be strengthened by a militia. Whoever was unwilling, or was unable, to sustain the honour of the military estate, should buy himself off by payment of money.' For the Chronica Majora, see M Paris, Matthaei Parisiensis, Chronica Majora, vol (Cambridge Library Collection - Rolls, 2012).
} 
they could buy themselves out of this - which is what the Crown really wanted since it could, then, use the money for mercenaries or spend it on other things.

In conclusion, from the Assize of Arms 1181, in practice, only limited numbers of the most able shire men were assembled to fight alongside: (i) those obliged to perform knight service; and (ii) hired mercenaries (including from Wales). 248

(n) Edward I (1272-1307)

Edward I (1272-1307) was a warrior - fighting on the continent and against the Welsh and Scots. Yet, there was rising opposition during his reign to this from both nobles and the shire militias.

- $\quad$ as noted before (see (k) the nobles asserted that their tenurial military obligation did not require them to fight abroad, only in England;

- $\quad$ further, Parliament began to involve itself in seeking to limit the power of the Crown to wage war, in part because of the ruinous cost. Thus, Parliament moved to limit the Crown's prerogative to raise taxes, to fund war.

The two - nobles and Parliament - began to work together since they clearly saw that the Crown was intending to develop a national (and not just a shire) army, which would be a loss to the power of both. Thus, in 1297, when Edward I (1272-1307) sought to raise money for war abroad (in France) this was opposed by Roger Bigod ${ }^{249}$, Humphey de Bohun ${ }^{250}$ and other nobles. Their refusal led to the Confirmation of the Charters 1297 (which is treated the same as an Act). Section 6 (which is still extant) stated:

for no business [of war] from henceforth we shall take such manner of aids, tasks, nor prises [i.e. customs duties], but by the common assent of the realm, and for the common profit thereof, saving the ancient aids and prises due and accustomed. ${ }^{251}$

This (forced) acceptance by the Crown that it could not impose taxes ('tasks') to raise armies without the assent of Parliament severely limited the ability of the Crown to wage war, especially, abroad (which included Wales, Ireland and Scotland). ${ }^{252}$ However, Edward I had already adopted another tack to get round his nobles and Parliament. He recruited soldiers by 'indenture' (a sealed contract). ${ }^{253}$ This avoided issues as to allegiance (problematic in the case of knight service). It also avoided the shire militias, which were not up to much. Instead, the Crown (as on the continent) secured professional English mercenaries who were paid for their service and, thus, were more likely to secure victory (being attracted to the sums made from spoil (booty) and from ransoms). By the end of Edward's reign in 1307, military service was provided by means of:

- tenurial service (including distraint);

- contract (indenture);

- men selected from shire arrays.

The first two were regarded as voluntary. The third was less so. Yet, in practice, shire men (a point often overlooked) could buy themselves out of their military obligation, which had long been possible. Finally, Edward I (1272-1307) moved to militarise the shire arrays by replacing the sheriff who summoned them with military commanders (captains). Maitland summed up the position:

Edward I [1272-1307] commissions certain of his servants to choose out a fixed number of able-bodied men from their respective counties. In other words he issues commissions of array. The forces thus levied he pays at his own cost. The troops from a county are under the command of a royal capitaneus or captain, in whom we see the forerunner of the lord-lieutenant in later times. The sheriff would naturally be the head of the county force, and so in theory he remains; it is he who can raise the power of the county, the posse comitatus, for the pursuit of malefactors; but for actual warfare an annual officer (and permanent sheriffs the country will not stand) is not a good commander. So the sheriff loses his military functions at a time when the institution of permanent justices is sapping many other of his powers. ${ }^{254}$

In conclusion, Edward I (1272-1307) was seeking to develop a volunteer national army, comprising free enlistment with Parliament paying. However - while this would have ended tenurial military service and shire arrays - the nobles and Parliament opposed it, since it would have given the sovereign too much power and he would have, soon, supplanted them. Edward II (1307-1327) and Edward III (1327-1377) also sought to achieve this, in vain. A national army was not come until 1689 - at the cost of loss of power by the Crown.

\footnotetext{
${ }^{248}$ Wales was not part of the realm until its annexation in 1284 by the Statute of Wales. Thus, it was foreign territory for the purpose of any array.

${ }^{249}$ Earl of Norfolk and Suffolk and Marshall of England.

${ }^{250}$ Earl of Hereford and Essex and Constable of England.

251 The original version was in French.

252 'Tasks' was the Anglo-Norman word for 'tax'. See n 83. The Statute concerning Tallage (still extant) is likely a prior draft (or a petition) and not an Act as such. Ibid, pp 536-40. See also Stephenson, n 150, p 165.

${ }^{253}$ Wilkinson, n 242, vol 3, p 224 (cites an indenture of 1287).

${ }^{254}$ Maitland, n 9, p 277. For a commission of array from 1282, see Stephenson, n 150, pp 161-2.
} 


\section{(o) Edward II (1307-27) \& Edward III (1327-77)}

The reign of Edward II was disastrous, characterised by lost wars, corruption, baronial opposition and his own abdication and death. As early as 1311, the ordainers (powerful barons who opposed Edward II) demanded that the sovereign not undertake any war without Parliament's consent. Thus, the Ordinances of 1311, art 9 stated:

we ordain that..the king shall neither go out of the kingdom nor undertake an act of war against anyone without the common consent of his baronage.... and that in Parliament. ${ }^{255}$

Edward had these Ordinances overturned in 1322 (by the Statute of York). ${ }^{256}$ However, the barons continued to oppose him, demanding that Parliament must consent to any war. For their part, the shire men sought to prevent their having to serve in war outside their shire without the consent of Parliament - which Edward II (1307-27) had often sought them to do (in Scotland and in France). Also, to prevent Edward II from forcing the shires to pay for additional weapons and costs. ${ }^{257}$ This led to an Act of 1327 in the reign of Edward III (1327-77) which was directed to military service and limiting its abuse. Wilkinson referred to the petitions by the Commons and the replies of Edward II (1307-27), as well as the later formulation of the Act.

Petition. 'the commons petition that no men shall be compelled in future to go to war against their wish in lands where they have no obligation to serve, against their manner of holding or - in the lands where they are obliged to perform service - in any other manner than that which they form of holding demands. And that the men of the commons shall not be compelled to arm themselves at their own cost against the form of the [Statute of Westminster 1285], and not to go outside their said counties except at the cost off the king.

Reply. As to the petition regarding going to war, it pleases the king and his [privy] council that they should not be charged to arm themselves otherwise than in the time of his ancestors, not to go outside their counties except in the case of necessity through the sudden invasion of foreigners into the realm; in which case let what has been customary in the past be done for the defence of the realm.

Petition...because commissions have been sent to certain persons of the said counties to array men-at-arms and to pay whilst leading them to Scotland and in Gascony at the cost of the commons and of the arrayers and the leaders without receiving anything from the king; whereby the commons and arrayers and leaders have been greatly distressed. Wheretofore they pray remedy, so that, when the king sends his commissioners for matters offending him, the execution shall be at the cost of the king, and that nobody be distrained to go to Scotland or Gascony or any part of the realm, nor to do any other service which his holdings ought to do.

$\underline{\text { Reply. }}$. Regarding the point touching the commission of arrayers and leaders of men, it seems to the [privy] council that it should not be done in future. ${ }^{258}$

Thus, the Act of 1327 stated:

the king wills that no man, henceforth, shall be charged to arm himself, differently from what he was accustomed in the time of his forefathers, kings of England; [i.e according to the Statute of Winchester 1285] and that

no man shall be compelled to go out of his shire, except when necessity requires through the coming of strange enemies into the realm; and then, it shall be done, as has been done in the past for the defence of the realm.

This translation taken from the Statutes of the Realm (which is generally taken as the authoritative translation), is, as previously noted (see 15(g)) different from the wording of Foster 'in case of sudden [foreign] invasion or formidable insurrection'. The words in italics are simply not in the Act. And, any invasion is a foreign one which Foster later noted. ${ }^{259}$

- this Act of 1327 is important since it is the only substantive basis on which Foster made his observation as to the Crown's ability to conscript for the army (re foreign invasion);

- the words in the 1327 Act: 'then it shall be done as hath been used in times past for the defence of the realm' are opaque. Foster thought them simply a reference to commissions of array. ${ }^{260}$ More probably, it was a reference to: (a) how the shire men would be paid if they served outside the shire; ${ }^{261}$ and (b) the Confirmation of the Charters 1297 which required the consent of Parliament to finance any war.

In other words, the real intent of this Act of 1327 seems to have been (to paraphrase):

no person in the commission of array [in the shire militia] can be compelled to fight outside his shire save in the case of a foreign invasion and, this, only with the consent of Parliament...

\footnotetext{
255 See Stephenson, n 150, p 194.

${ }^{256}$ Ibid, pp 204-5.

${ }^{257}$ Stubbs, n 207, vol 2, p 298 'The abuse of the system, which threw the expense of additional arms and maintenance on the townships amd counties, began under Edward II (1307-27), although down to his last year his writs make arrangements for the payment of wages.'

${ }^{258}$ Wilkinson, n 232, vol 3, pp 226-7.

${ }^{259}$ Foster, n 162, p 175 'cases such as that of a foreign invasion'.

${ }^{260}$ See $\mathrm{n} 191$.

${ }^{261}$ See 18 Edw st 2 c 7 (When soldiers wages shall begin), see n 190.
} 
Such an interpretation appears to have been the view of Coke (see 15(q)) but not of Foster (who did not mention Coke). As to the summoning of only selected men from the array of arms, the procedure can be seen from a writ of 1326 cited by Wilkinson:

It is agreed by the king and his council that the earls and other magnates who are appointed keepers and chief leaders of men-at-arms, horse and foot, in different counties should first of all speedily cause the arrayers of the said counties to come before them at a certain time and place, with all the men-at-arms and footmen that the arrayers have arrayed And at first a certain hundred shall have in it the men arrayed in the same hundred. Then the said earls and chief advisers and councillors, by themselves or by other good and sufficient men sworn for this purpose, shall survey the men thus arrayed in that hundred and from them, by their own discretion and for the relief of the people, shall elect [choose] a certain number of the best and most powerful and best armed and cause their names to be written down, and arrange them in twenties and hundreds, and charge them to be ready, day and night, to come before them at whatever time and place they were warned to...And also the said earls and magnates shall have talk with the most worthy of the said counties and shall charge them to ordain how one can best find and raise the wages for the men whom they have taken or caused to be taken by election from the rest, that is to say until they come to the place where all the host [i.e. the combined army] is to meet... ${ }^{262}$ (italics supplied)

As to the Act of 1327, Wilkinson concluded:

However much this Act [of 1327] might be evaded, it set forth strict limitations on the royal demands for military service and, even more important, brought the whole problem [of commissions of array being forced to serve outside their shire] for the first time within the purview of Parliament. ${ }^{263}$

In conclusion, the Act of 1327 is no support for the contention of Foster as to the existence of any Crown prerogative to summon all able-bodied men for the army. His view also contradicts that of Coke whom Foster forgot to mention in his judgment (see (q)). However, prior to this, another relevant Act should be stated.

\section{(p) Act of 1351}

The background to an Act of 1351 (repealed in 1863) - to which indirectly Foster refers to in his judgment ${ }^{264}$ was in consequence of a new idea of Edward III (1327-77) to evade the effect of the Act of 1327 by requiring landowners to fund soldiers in proportion to their wealth. Wilkinson noted that, in part because of the Act of 1327:

under great pressure of his French war...in 1345-6, [Edward III] tried a remarkable experiment to find a new and more effective method of obtaining military service outside the feudal levy [i.e. the tenurial obligation of knight service], which had now ceased to have any practical importance. The essence of his scheme was a national responsibility for the provision of soldiers, based on the simple possession of land. All landowners were to supply and (possibly) equip men for the king's service, according to their wealth. The imposition was free of Parliamentary control; it was made only with the advice and assent of the prelates, nobles and others of experience. ...The scheme never had a real chance of success. The Commons insisted on parliamentary consent. The new method of finding men-at-arms by using the landowners as involuntary contractors was quickly brought under strict Parliamentary control by the Statute of 1351 [i.e. the Act of 1351] ... The twin failures of Edward I and Edward III made inevitable a great expansion of the indenture and of pay [i.e. hiring mercenaries and paying better wages]... ${ }^{265}$

This Act of 1351 stated:

no man shall be constrained to find men-at-arms, hobelars ${ }^{266}$ or archers, except those who hold by such services, unless by common assent and grant made in Parliament. (italics supplied)

The reference to 'services' referred to:

(i) those bound by knight service (now effectively obsolete); or

(ii) mercenaries - who undertook military service pursuant to an indenture (contract) and were paid money (prest money) for it.

The practical effect of these two Acts of 1327 and 1351 was clear. By limiting the power of the Crown to wage war (in particular, the Act of 1327 making it clear that the shire militia could not fight outside their shire apart from in the case of foreign invasion) Edward III (1327-77) turned towards a professional voluntary army, using mercenaries. This proved to be (in the short term) highly profitable to the Crown and its entourage, by reason of the resulting plunder and ransoms. Ormrod noted:

After 1341 it became common for military commanders to draw up contracts or 'indentures' with the crown, promising to provide a specified number of soldiers for an agreed period of time, and receiving guarantees that all their resulting expenses would be met by the royal exchequer. Such contracts gave the nobles several distinct advantages. The employment of their own armies in the king's service inevitably gave them a greater influence over

\footnotetext{
${ }^{262}$ Wilkinson, n 242, vol 3, p 226.

${ }^{263}$ Ibid, p 208.

${ }^{264}$ Foster, n 162, p 175. For the 1351 Act, see 25 Edw III c 8 (Finding of Men at Arms).

${ }^{265}$ Ibid, pp 208-9.

${ }^{266}$ A 'hobler' (hobelar) was a soldier who rode a 'hobby' or light (small) horse.
} 
strategy. The development of the indenture also put an end to the question of whether or not noblemen ought to receive payment for military service [i.e. knight service]. Wages were now the norm for all ranks, and ranged from $13 \mathrm{~s} 4 \mathrm{~d}$ a day for a duke to $2 \mathrm{~d}$ a day for an ordinary infantry soldier. Even more important were the arrangements laid down in indentures for the disposition of prisoners and plunder. Edward III [1327-77] managed to establish by the 1350 s that important prisoners ought to be reserved to him, and a third of all the profits of war should pass to the Crown. ${ }^{267}$

\section{(q) Coke Views of the Acts of 1297,1327 \& 1351}

It is useful to look forward, for a minute, to consider the view of Coke on the Acts of 1327 and 1351 as well as the Confirmation of the Charters 1297 which latter piece of legislation Foster failed to deal with in his judgment. It seems clear that Coke (writing in the 1640's) was of the view - by reference to Acts of 1327 and 1351 - that the Crown could not wage war:

- unless with the consent of Parliament; or

- where the Crown was hiring indentured soldiers at its own cost; (i.e. voluntary) or ${ }^{268}$

- where the service obligation was tenurial (i.e. voluntary); or $^{269}$

- where the shire militias did not have to go abroad. ${ }^{270}$

However, Coke also accepted the reality of the situation - that the Plantagenets [1154-1485] had breached the strict law and had acted, at times, without Parliamentary approval. Thus, he referred to the frequent protests of the House of Commons in ancient times that:

they were not bound to the maintenance of war in Scotland, Ireland, Calice [Calais], France, Normandy, or other foreign parts, and caused their protestations to entered into the Parliament Roll where they yet remain; which in effect agrees with that, which upon like occasion was made in this Parliament of 25 Ed 1.' (i.e. the Confirmation of the Charters 1297). ${ }^{271}$

Thus, to Coke, the Acts of 1327 and 1351 would have been no basis for asserting a Crown prerogative to impose compulsory military service on all English male subjects. Instead, his belief (it seems clear) was no man could be conscripted by the Crown to army service unless Parliament consented.

In conclusion, it seems that Coke would not have agreed with the view of Foster as to any Crown prerogative to conscript without the assent of Parliament - which is (possibly) why Foster did not choose to cite him in his judgment in Broadfoot (1743).

(r) Wars of the Roses \& Tudor Period

Despite the position being clear from medieval times - that no able-bodied man (aged 15-60) chosen from a commission of array was obliged to go to war abroad - in the bitter Wars of the Roses (1355-1485) and the struggle for dynastic succession both the Crown and the opposition ignored the constitutional position, as Maitland noted:

During the Wars of the Roses both sides used the king's name for commissions of array, ${ }^{272}$ and the country got thoroughly accustomed to intestine war, compulsory service and extorted loans and benevolence. ${ }^{273}$ The statutes [Acts] of Edward III [1327-77] [i.e. Acts of 1327 and 1351] remained on the statute book; so did the Statute of Westminster [1285]..$^{274}$

However, in the Tudor period (1485-1603), things calmed down since no standing army was maintained. Maitland noted:

\footnotetext{
${ }^{267}$ WM Ormrod, Edward III (2005), pp 115-6. As for tenurial military service, it seems that, in his 50 year reign, Edward III only called them up in 1327, see Plucknett, n 16, p 672, n 92 citing AE Prince, 'The Army and the Navy', in JF Williard \& WA Morris (eds), English Government at Work 1327-1336, vol 1, p 334.

${ }^{268}$ Maitland, n 9, p 278 noted that 'The army whereby Henry V [1386-1422] won his victories in France consisted partly of soldiers voluntarily enlisted who had the king's wages, partly of forces raised by lords who served the king by indenture, by special bargain [i.e. contract].' Thus, the terms of the Acts of 1327 and 1351 (as well as the Confirmation of the Charters 1297) were not breached.

269 Ibid.

${ }^{270}$ Feilden, n 10, p 307 the 'militia which, by an Act of 1327, finally confirmed in 1402, was not to serve out of its own county [shire], except in the case of invasion'.

${ }^{271}$ Ibid. Maitland, n 9, p 278 'Apparently those statutes [of 1327 and 1351] were habitually broken or evaded. In 1402 they were confirmed by statute (4 Hen IV c 13), and they seem to have been observed during the Lancastrian reigns.'

${ }^{272}$ As Stubbs noted, n 207, vol 3, p 281, commissions of array had become disused from the early years of Henry IV [1367-1413]. Edward IV resuscitated them for his war with Scotland. Ibid, pp 285-7. The main illegalities were illegal taxation to fund the levies (cf. Confirmation of the Charters) and foreign wars without consent of Parliament (cf. 1327 Act). Bowyer, n 8, p 487 'the form of the commission of array was settled in the $5^{\text {th }}$ of Henry IV [1404], so as to prevent the insertion therein of any new penal clauses.' See also Stephenson, $\mathrm{n} 150$, $\mathrm{p} 259$.

273 The were extorted because they were illegal, being contrary to the Confirmation of the Charters 1297 , see $\mathrm{n} 83$.

${ }^{274}$ Maitland, n 9, p 278.
} 
The Tudor despotism was not enforced by any standing army... One or two hundred yeomen of the guard and a few guards in the fortresses were the only soldiers that the king kept permanently in his pay. ${ }^{275}$ Commissions of array, however, were issued from time to time; and counties were compelled to provide soldiers even for foreign service, and the statutes of an earlier time seem to have been disregarded and perhaps forgotten. ${ }^{276}$

Maitland also referred to an:

important Act of 1557 (4 and 5 Philip and Mary, c 3) [which] takes no notice of the old Acts, but speaks of mustering and levying men to serve in the wars as a recognised legal practice, and it seems to me, implicitly sanctions impressment by means of commissions of array, even impressments for foreign service. ${ }^{277}$

The Act of 1557 was important in that it recognised the problems with the shire militias:

- thus, it expressly referred to the fact that 'a great number' of people had absented themselves from the general muster and others had bought themselves off by paying the muster masters, and that this was at great peril to the realm;

- $\quad$ the Act, then, imposed punishment (imprisonment and fines) for those who failed to present themselves at muster (with the correct armour) or from parting from their captain (the muster master) without permission (licence). There was also heavy penalty imposed on muster masters who, for reward, let people off from the muster.

Maitland appears to have over-stated the position as to foreign service ${ }^{278}$ since the Act said nothing about it. It, also, expressly did not apply to those who owed tenurial military service. ${ }^{279}$ Commissions of array seem to have been by way of Crown proclamation from 1513-45 (at least) ${ }^{280}$ until the Act of 1557 referred to above. While the minimum age for men was now, it seems, raised to 16 (from 1539 , at least) ${ }^{281}$ it is unclear what the upper age limit was. Those taken into battle from the musters (which were annual, taken in the summer) were still limited to those especially who were especially skilled. Not least, because of the cost. ${ }^{282}$ For example, Instructions for General Musters (1572) provided:

The principal intent of the queen's majesty...is to have perfect knowledge of the numbers, qualities, abilities, and sufficiency of all her subjects in that county...from the age of [16] years upward, that may be found able to bear armour or to use weapon on horseback or on foot; and out of that... number, being viewed, mustered, and registered, to have a ...sufficient number of the most able to be chosen and collected, to be by the reasonable charge of the inhabitants in every shire tried, armed, and weaponed, and so consequently taught and trained...for the service and defence of [HM], her crown, and realm against all attempts both inward and outward... Item because of the training and exercise of a multitude of people in their armour and weapons... seem costly chargeable...[the commissioners]... shall consider and determine what were or may be convenient number in every part of the shire to be collected out of the total number, meet to be sorted in bands, and to be trained and exercised in such sort as may...reasonably be bourn by a common charge of the whole country... ${ }^{283}$

\footnotetext{
${ }^{275}$ The yeoman of the guard created by Henry VII (1485-1509) do not appear to have exceeded 200. H Hallam, The Constitutional History of England (1897), p 131 'A kind of regular troops...was maintained in the very few fortified places where it was thought necessary or pracricable to keep up the show of defence; the Tower of London, Portsmouth, the castle of Dover, the fort of Tilbury, and, before the union of the Crowns [in 1603], Berwick and some other places on the Scottish border....their whole number must have been insignificant.'

${ }^{276}$ Maitland, n 9, p 278.

${ }^{277}$ Ibid.

${ }^{278}$ Maitland may have been incorrect as to foreign service. DL Keir, The Constitutional History of Modern Britain since 1485 (9 $9^{\text {th }}$ ed, 1969), p 35 'Tudor rule was supported by any large professional army. The outbreak of foreign wars necessitated the enlistment of mercenaries, and the raising of troops within the realm by contract [indenture] with persons prepared to raise, officer, pay and equip regiments of their own. The Crown had a number of permanent garrisons in such fortresses as Calais and Berwick, a small cavalry force of gentlemen pensioners, an infantry force of yeoman of the guard, and a train of ordnance under a Master-General, whose office, dating from 1483, was of very recent origin.'

${ }^{279} \mathrm{~S} 7$.

${ }^{280} \mathrm{~J}$ Baker, The Oxford History of the Laws of England 1483-1558 (2003), p 72 refers to proclamations of 1513, 1522, 1532 and 1545. These arrays were when put on a statutory basis by an Act of 1558 .

${ }^{281}$ e.g. Stephenson, n 150, p 399 refers to a Certificate of Muster Masters (1539) 'This is the certificate of...three of the king's commissioners appointed for the trial and view of all persons armed within the hundred of [ ] in the county of Stafford, above [16] years, as well horsemen, footmen, bowmen, and billmen within the said hundred...' Also, Ibid, Instructions for General Musters (1572), Ibid 'all able persons from [16] upwards...'. See also MA Thomson, A Constitutional History of England (1938), vol 4 (1642-1801), ch 4. Those held to be exempt from militia service were prelates, clergy, peers, privy councillors, judges, officers of the Queen's court of record. Ibid, pp 88-9.

${ }^{282} \mathrm{Keir}, \mathrm{n} 278$, p 37 'A force like this, composed of and commanded by men who were mere amateurs in the art of war, could never become efficient and was sometimes not even wholly dependable..'. It is for this reason that the general musters of men became limited to mustering only those of military worth (see Instructions for General Muster in 1572) which gave rise to the train bands of James VI (1603-25), see Stephenson, n 150, p 397.

${ }^{283}$ Ibid.
} 
The muster masters were appointed by the lord lieutenants of the counties, themselves appointed by the Crown. ${ }^{284}$ The office of lord lieutenant was a military one. It is said they were first appointed in 1550 by legislation. ${ }^{285}$ However, there are indications of such an office prior to that. ${ }^{286}$ The task of the lord lieutenant may be seen from a Commission of 1576 :

Elizabeth...queen to [ ] we have assigned you to be our lieutenant within our county of [ ] and [we] do by these presents give full power and authority unto you that you may from time to time may levy, gather, or call together all...our subjects...dwelling within the said county...meet and apt for the wars; and them to try, array, and put in readiness, and them also after their abilities...sufficiently cause to be armed and weaponed; and to take the musters of them from time to time.... and also the same our subjects, so arrayed, tried, and armed ...meet and apt for the wars...to conduct and lead, as well against all...enemies as also against all...rebels, traitors, and other offenders and their adherents... ${ }^{287}$ (italics supplied)

As for the 'arms' (military weapons) the shire militias were required to have (bear), such was specified in another Act of 1557, one which replaced the Assize of Arms 1181 and the Statute of Westminster $1285 .{ }^{288}$ It is to remembered that bearing arms was a distinct legal obligation to that of militia men being required to fight within or out of the realm.

In conclusion, there was no standing army in Tudor times and some attempt was made, from 1557, to imprve the quality of the shire militias and the weapons which they were required to arm themselves with.

(s) Shire Militias - 1603-60

The Act of 1557 (above) which had updated the obligation on subjects to bear arms (that is, to keep military weapons for personal use) was repealed by an Act of 1603. ${ }^{289}$ Maitland stated:

this statute [of 1557] was repealed in 1603 ... No reason is given for the repeal; Hallam suggests that the accession to the English throne of the king of Scotland had removed the chief necessity for a defensive force. But the repeal had a perhaps unexpected effect. Until 1850 it was our law that if statute A be repealed by statute B, and then statute B be simply repealed by statute C, statute A is thus revived - so the Statute of Westminster [1285] came to life once more. Then in the days of Charles I [1625-49] it became matter of hot debate whether the armed force which the old statutes created was at the king's disposal. This [shire] force was just acquiring the new name of militia, and the control over the militia became one of the chief points of controversy and Parliament. ${ }^{290}$

It is suggested that the reason for repealing the Act of 1557 was fairly prosaic. The changing nature of warfare required more sophisticated weapons than those required by the Act. Further, the same reflected the recognition that professional armies were vital to winning wars, rather than amateurs. Thus, for the Crown, in the later part of the reign of James I (1603-25) - the war years of 1621- $9^{291}$ - and that of Charles I (1625-49), the need for a standing army of professional soldiers became urgent. After all, they only had:

- a small force of guards and garrisons

- the shire commissions of array (now termed the militia (army)),

both of which were inept. Further, in $1640,{ }^{292}$ the tenurial military tenants (those obliged to perform knight service) were called out for the last time to fight in Scotland. However, they had long been near useless, since their service was only 40 days (after which the sovereign had to pay) and most had avoided service by buying themselves centuries ago (through scutage). What to do?

\footnotetext{
${ }^{284}$ See GS Thomson, Lords Lieutenant in the Sixteenth Century (1923).

2853 \& 4 Edw VI (1550), c 5, s 13. See also 2 \& 3 Edw VI (1549), c 2.

${ }^{286}$ GR Elton, The Tudor Constitution (1960), p 451-2. The office of lord lieutenant was... an addition made by the Tudors. It took its origin in military needs. Henry VIII (1507-49), in particular, sometimes appointed temporary deputies in the north and west whom he called lieutenants; at the same time it became customary to commission local magnates to supervise the levying of shire musters and to be responsible for the military forces of a given district..' See also Scott Thomson, Lords Lieutenant (1923).

${ }^{287}$ Ibid, p 396.

${ }^{288}$ Maitland, n 9, pp 278-9 'Another statute of this same year 1557 (4 and 5 Philip and Mary, c 2) expressly repealed so much of every statute of earlier date as concerned the finding or keeping of horse or armour; and it enacted a new scale of armour, which replaced that ordained by the Statute of Winchester [1285].'

289 James I c 5 (1603).

${ }^{290}$ Maitland, n 9, p 279. For Hallam, see n 275, vol 2, p 133.

${ }^{291}$ Keir, n 278, p 165 'In the war years of 1621-9 it [the privy council] provided - sometimes acting through a Council of War - for the enrolment of troops, if necessary by compulsion, for their organisation, supplies, transport, and pay...'. However, this misunderstands the position since the Crown would assert (and was asserting) there was no compulsion since the troops were paid and thus were voluntary (by acceptance a contract of employment, prest money). See generally, SD White, Sir Edward Coke and the Grievances of the Commonwealth (1979). Also, Gardiner, n 172, pp xvii- xix.

${ }^{292}$ Hallam, n 275, vol 2, p 129.
} 
- Both James I (1603-25) and Charles I (1625-49) had a poor relationship with Parliament and the latter was (very) reluctant to finance any (foreign) war. In part, because it seemed clear these sovereigns intended to reign without Parliament and they would use an army (and any money provided) to suppress it.

Thus, both James and Charles used illegal methods to exact money, to modernise and develop the shire militias. ${ }^{293}$ The issue as to who, legally, should exercise command of the same ${ }^{294}$ brought matters to a head and precipitated the Civil War (1642-9), leading to the dethronement, and execution, of Charles in $1649 .{ }^{295}$ Prior to this, the preamble to an Act of 1641 for raising of soldiers to fight in Ireland (which was 'abroad' for the purpose of the shire militias and which Act later expired) declared:

by the laws of this realm none of [HM's] subjects ought to be impressed or compelled ${ }^{296}$ to go out of his county [referring to the shire militias] to serve as a soldier in the wars, [referring to the militia] except in the case of necessity of the sudden coming in of strange enemies into the kingdom, or except they be otherwise bound by tenure of their lands and possessions. ${ }^{297}$ (italics supplied)

This preamble was important since (on one reading) it confirmed the Act of 1327; the reference to 'except in the case of necessity of the sudden coming in of strange enemies into the kingdom' being a direct reference to the Act of 1327 (see 15(0)).

- $\quad$ Thus, this preamble (clearly) seemed to end any Crown prerogative since it recognised that no male subject (of whatever age) could be compelled to serve in the militia - save in the case of a foreign invasion (it excepted any tenurial military obligation). Further, this statement, as well as that in the Act of 1327 put matters on a statutory footing. There was no room for a Crown prerogative;

- Plucknett thought the 1641 Act was the last time any impressments (by which he meant compulsory service) for the army was exercised by virtue of the royal prerogative. ${ }^{298}$ This would appear to be so, since the Act empowered Charles I to levy troops compulsorily for the suppression of the Irish rebellion - which is not the same as the exercise of a common law prerogative.

However, things were not above all doubt since the statement was in a preamble. Thus, there was room for doubt. Given this, reliance tends to be placed on the later Act of 1662 to make matters definitive (see 15(t)).

As it is, by 1642, Parliament was asserting - in any case - that the shire militias ought to be in their hands. ${ }^{299} \mathrm{It}$ brought in a Bill to this effect. However, Charles I (1625-49) refused to give assent. Hallam noted:

The aim of the Houses [of Parliament]...in the bill for regulating the militia, presented to Charles in February, 1642, and his refusal to pass which led by rapid steps to the civil war, was...to place the command of the sword in the hands of those they could control; nominating in the bill the lords lieutenant of every county, who were to obey the orders of the two houses, and to be irremovable by the king for two years. ${ }^{300}$

Why did Charles I refuse to assent and, thereby, enter into direct confrontation with Parliament? In part because he knew that all military power would, thereby, slip from his hands and be lost. However, he, also, believed (wrongly) that he would win the battle with Parliament.

In conclusion, an Act of 1641 confirmed an Act of 1327 that the shire militias were not obliged to serve outside their shires except in the case of foreign invasion.

(t) The Restoration (1660) -1688: Statutory Organisation of the Militia

After the restoration in 1660, there was much legislation. In the military sphere, 3 Acts, in particular, are of note:

\footnotetext{
${ }^{293}$ Such as forced loans, billeting soldiers, imposition of martial law.

${ }^{294}$ Plucknett, n 16, p 125 'The command of the militia, as the local forces were usually denominated, formed the final ground of rupture between Charles and his parliament, the latter having passed ordinances (February 16 and March 5, 1642) superseding the king's commissions of lieutenancy by the appointment of fifty-five commissioners of array, with power to suppress 'all rebellions, insurrections and invasions.'

${ }^{295}$ For a potted history see Keir, n 278, ch 4.

${ }^{296}$ These words appear to be used as synonyms. Thus, they did not affect mercenaries; nor anyone who voluntarily enlisted in the shire militias. See also the 1662 Act, see 15(t) which assists such a reading.

${ }^{297}$ Ibid, p 399. The Act was 17 Car 1 c 28 (1641) ('An Act for raising of Soldiers for the Defence of England and Ireland'). The wording in italics refers to tenurial military service. See also Gardiner, n 172. pp 242-5.

${ }^{298}$ Plucknett, n 16, p 399, n 17 'Since this statute, impressment for army has never been exercised by virtue of the royal prerogative; but under the authority of parliament it has occasionally been resorted to, more especially during the American war, as, e.g. in 1779 , by statute 19 Geo 3 , c 10. In later times, however, this odious violation of personal liberty - which has nothing in common with a national conscription applicable to all able-bodied citizens alike - has not been practised for strengthening the land forces, which have been recruited by enlistment, stimulated by bounties.' Chalmers, n 11, (in 1922), p 143 'Impressment for military service was declared illegal by 16 Charles 1 c 28 .'

${ }^{299}$ Maitland, n 9, p 326 'in 1642 the Houses [of Parliament] asserted that the power of the militia (as it was called) was or at all events ought to be in their hands. This... was one of the immediate causes of the Civil War [1642-9]; the king was required to a bill putting the militia, as the old county forces [commissions of array] were now called, beyond his control. That the militia and all fortified places should be in such hands as parliament should appoint, was one of the Nineteen Propositions tendered to him at York in June 1642. During the [cvil] war which followed both sides had resort to martial law for the government of their armies.' For the 19 Propositions, see Stephenson, n 150, pp 489-90, especially $9,15 \& 16$
}

${ }^{300}$ Hallam, n 275, p 135. See also Gardiner, n 172, p xxxvii. 
- $\quad$ Feudal Tenures Act 1660. The Act abolishing Feudal Tenures 1660 ended any obligation to provide military service by reason of landholding. ${ }^{301}$ Thus, all tenurial military service ended. This simplified matters greatly in the military sphere since this left only the shire militias to be concerned with;

- Command of the Militia Act 1661. A temporary Act, it confirmed that the supreme government, command and disposition of the militia (by sea and land) was held by the sovereign; ${ }^{302}$

- Militia Act 1662. An Act made provision for calling together, arming, and arraying the (shire) militia, by the king's lieutenants of counties. Also, for charging the cost upon the landholders in proportion to the value of their estates. ${ }^{303}$ This Act also provided that - in the event of rebellion or invasion - the militia might be used anywhere in England and Wales. ${ }^{304}$

The Militia Act 1662 was not cited by Foster. However, as previously noted, it defeats his argument as to any Crown prerogative to conscript. Instead, it statutorily empowered the sovereign to undertake certain acts with regard to the shire militias and it was not contained in any preamble, unlike the Act of $1641 .{ }^{305}$ Thus, the 1662 Act, s 1, stated:

Be it therefore enacted...that the king's most excellent majesty, his heirs and successors shall and may from time to time as occasion shall issue forth several commissions of lieutenancy as [HM] shall think fit for [England, Wales, Berwick on Tweed $]^{306}$ which lieutenants shall have full power and authority to call together all such persons at such times and to arm and array them [as later indicated] and to form them into companies, troops and regiments and in the case of insurrection rebellion or invasion them to lead conduct and employ... and to train exercise and put in readiness and also to lead and conduct the persons so to be armed arrayed and weaponed.

Also:

- $\quad$ Financing the Militia. No person was to be charged with finding a horse, horseman and arms unless they had an annual income of $£ 500$ (or an estate of $£ 6 \mathrm{k}$ in money or goods). As for finding a foot soldier, the sum was $£ 50$ (or an estate of £600). A person could not be charged for both in the same county. Payment of the wages of the soldiers was to be effected by levying a rate on the county;

- General Muster. This was to be held only once a year (and special training for single companies was to be no more 4 times a year and not above 2 days).

Importantly, people could buy themselves out - thus, those compelled to find a horse or a foot soldier were not compelled to serve in person but might find a sufficient proxy, providing the captain agreed. Finally, the Act did not give any power:

for the transporting of any of the subjects of this realm or any way compelling them to march out of this kingdom [i.e. to go out of England and Wales] otherwise than by the laws of England [a reference to the Act of 1327] ought to be done [i.e. only with Parliament's consent]. ${ }^{307}$

This Act of 1662 - although nominally recognising the sovereign as C-in-C - actually passed all the power of the militia to the lords lieutenant who were landed gentry, as Tanner noted:

It is true that the lords-lieutenant were once more nominated by the Crown, but in actual practice the choice of the Crown was limited to the magnates of the shire. The lords lieutenant themselves appointed the officers, and this had the effect of restricting these posts to the landed gentry...the power of the sword had passed to the magnates of the shire. This was their guarantee against military government and arbitrary power; and it was this force which drove out James II [1685-8] and accomplished the revolution of 1688...There was nothing to prevent the king raising troops by contract or voluntary enlistment; but they had to be fed, and lodged and paid, and kept under military discipline.... and the Crown had no money to spare for paying an army. At a later time [i.e. post-1688] the problem was solved by Parliament itself granting funds for a standing army...but the Parliaments of Charles II [1660-85] would do nothing of the kind... ${ }^{308}$

\footnotetext{
30112 Car II c 24 (1660) 'An Act for taking away the Court of Wards and Liveries etc). See Stephenson, n 150, p 536 for the same.

${ }^{302} 13$ Car 2 st 1 c 6 (1661) ('An Act declaring the Sole Right of the Militia to be in the King etc. ') for 'the sole supreme government of the militia and of all forces by sea and land is, and by the laws of England ever was, the undoubted right of the king and his predecessors, and that neither house of Parliament could pretend to the same'. See also Maitland, n 9, p 326 and Plucknett, n 16, p 125.

30314 Car 2 c 3 (1662) ('An Act for ordering the Forces in the several counties of this Kingdom'), ss 1 \& 2. See also Maitland, n 9, p 455.-6 . Also, 15 Cha 2 c 4 (1663) ('An additional Act for the better ordering the Forces in the several counties of this Kingdom'). Also, Thomson, $\mathrm{n}$ $281, \mathrm{p} 155$.

$304 \mathrm{~S} 1$.

${ }^{305}$ So had the Act of 1641 (see 15(s)) and the Command of the Militia Act 1661 (above). However, they were only temporary.

${ }^{306}$ In the case of Scotland, the militia was placed on a statutory basis in 1797, see Robertson, n 197, p 230.

${ }^{307}$ Ibid, s 31 .

${ }^{308}$ JR Tanner, English Constitutional Conflicts of the Seventeenth Century 1603-1689 (1962), p 225. Tanner explained why - -during the Interregnum [1649-60] the army had become an instrument of despotism.
} 
More importantly, in 1660, the Cromwelllian standing army had been disbanded, ${ }^{309}$ by legislation passed by the Convention Parliament in $1660 .{ }^{310}$ Maitland stated:

The Convention Parliament passed an act disbanding the army; the king [Charles II] assented; he also had some reason to dread a standing army. The Act of disbandment, however, sanctioned the continuance of 'the Guards and Garrisons'. The garrisons were to be placed in the condition in which they existed in 1637, and out of the residue of the soldiers the king was to be at liberty to retain a guard. The number of this guard was not specified. ${ }^{311}$ Throughout the reign and on to the [Glorious] Revolution [of 1688] no more than this was legalised. Controversy constantly broke out between king and Parliament as to military matters. In 1676 Charles [II] declared that he was going to war with France; parliament granted but [money was] not appropriated; ${ }^{312}$ war was not made; Parliament passed an Act for disbanding the army...Nevertheless Charles [II] and James [II] after him in one way and another kept the army on foot. James [II] seems to have had above 16,000 men. ${ }^{313}$

It was the latter fact that caused, in great part, the downfall of James II (1685-8), his flight abroad and the election of William III (1688-1702) and his wife Mary (1689-94) to the throne. The fear was that both Charles II and more so James II (1685-8) intended to raise up a standing army (and like Charles I (1642-9)) to rule without reference to Parliament. ${ }^{314}$ Wade (in 1931) noted:

The king [Charles II] was not, however, henceforth permitted to keep a standing army beyond ' guards and garrisons' of unspecified numbers. On this footing, with constant disputes between king and Parliament, the matter continued until the Revolution of 1688. The Bill of Rights [1688] provided that:

'The raising or keeping of a standing army within the kingdom in time of peace, unless it be with the consent of Parliament, is against the law.'

This provision was not due so much to the objection to military service as to the realisation that the army might be dangerous to the liberty of the subject in the hands of an unwise ruler. ${ }^{315}$

As it was, for present purposes, after 1660, there was no standing army as such (although Charles and James, surreptitiously built up their ' guards'). Moreover, the army was regulated by legislation (the Act of 1662). Thus, there was no exercise of any Crown prerogative to impose compulsory military service.

\section{In conclusion, post-1662, the militia was regulated by statute and the sovereign was only empowered to act in accordance with the same. He could not, thereafter, raise up an army by compulsory means.}

(u) Glorious Revolution of $1688-1907$

After the Revolution of 1688 and deposition of James [II], a standing army was established by legislation by means of annual Mutiny Acts, the first of which the Mutiny Act $1689^{316}$ declared in a preamble (following rhe Bill of Rights 1688) that:

whereas the raising or keeping a standing army within this kingdom in time of peace, unless it be with the consent of Parliament, is against law... 317

The shire militias of 1660 continued in much the same state ${ }^{318}$ until 1757 when - in panic at the prospect of French armament - they were reformed, with militiamen (aged 18-50) to be chosen by ballot to serve for a limited number

\footnotetext{
${ }^{309}$ Keir, n 278, p 235 'The Cromwellian army...was speedily disbanded... [by February 1661] thirteen cavalry and eighteen infantry regiments and fifty-nine garrisons had been disbanded.' During the period 1649-60, the shire militia had fallen into decay because it had been eclipsed by the professional army. See also Tanner, n 308, p 223. Plucknett, n 16, p 673 noted that the Cronwellian army was a regular army of 30,000 men.

31012 Car 11 c 15 (1660) (An Act for the Speedy Disbanding of the Army and Garrisons of the Kingdom).

${ }^{311}$ This was the major problem since it allowed Charles and James to increase the shire militias by some degree of stealth.

${ }^{312}$ I think he means 'but money was not appropriated'.

${ }^{313}$ Maitland, n 9, pp 326-7. For the disputes of Charles II (1660-85) with Parliament over military matters, see Thomson, n 281 , ch 11.

${ }^{314}$ It may be noted that James II (1685-8) prorogued Parliament at the end of 1685 and it never sat again during his reign, see Thomson, $\mathrm{n} 281$, p 160. For the surreptitious approach of Charles II and James II, see Plucknett, n 16, p 673

315 Wade, n 12, p 318.

${ }^{316} 1$ Will and Mary (1689) c 5. As Maitland noted, n 9, p 329, sometimes, annual renewal was forgotten. 'For a while this was not done with perfect regularity. On several occasions during the reigns of William [1688-1702] and Anne [1702-14] there was for a few months no mutiny act in force. Sometimes on the other hand the act was to endure for two years. But very soon the practice became settled of passing the act for one year only and of passing such an act every year. All along through the last century it was regarded as something exceptional, an evil of which we should get rid, if once we had a settled peace. And so for two centuries, year by year, the statute book was burdened by annual mutiny acts which always tended to become longer and longer.'

${ }^{317}$ This re-states the provision in the Bill of Rights 1688 .

${ }^{318}$ See Thomson, n 281, pp 294-7.
} 
of years. They were not compelled to leave their own country, save in the case of invasion or rebellion. ${ }^{319}$ Maitland noted that, in practice:

Very rarely indeed had the [shire] militia been drawn out and embodied. It was embodied during the Seven Years' War, [1756-63] again between 1778 and 1783, again between 1792 and 1803 [Napoleonic war]. ${ }^{320}$

They effect was that the shire militias became a body of men captained by the landed gentry who rarely saw service and where men could pay (with the agreement of their captain) for others to take their place. Further, their service was limited to 28 days in a year and their embodiment (mustering) could be dispensed with. Bowyer (in 1846) stated:

The Crown is empowered in cases of actual invasion, or imminent danger thereof, and in all cases of rebellion and insurrection, to call out the militia, and place them under military command; but under ordinary circumstances, by 55 Geo III c lxv [1815], the period during which they may be placed on duty is limited to [28] days in any one year; and the 57 Geo III c lvii [1817] authorises the queen to dispense with their being embodied at all during any year. Their pay, government, and liability, do not materially differ from those of troops of the line, except that they are only sworn to serve in Great Britain and Ireland, and the service in the latter country cannot exceed two successive years. $^{321}$

The words the 'Crown is empowered' is exactly right since these Acts (as from 1662) authorised the Crown to do things. They were not the exercise of the Crown prerogative at common law. After 1815, voluntary enlistment in the shire militias took effect ${ }^{322}$ - though the ballot was not officially suspended until $1865 .{ }^{323}$

\section{(v) Chitty (1820)}

The standard text on Crown prerogatives from 1820 was Chitty. ${ }^{324}$ Writing in 1820 , he stated:

Though, as just observed, the king has a right to require the personal service of every man able to bear arms, in case of a sudden invasion or formidable insurrection; and the allegiance due from the subject renders it incumbent on him to assist his sovereign on such occasions; ${ }^{325}$ yet except on such emergencies, and at ordinary times $[\mathrm{HM}]$ has no legal power to force any one to enlist in his armies. [i.e conscription] ${ }^{326}$ (underlining supplied)

However, his statement must be read in context since he said 'as just observed'. This was a reference to the shire militias (established by legislation in 1662) acting according to legislation governing the same. Thus, he had written:

With respect to the militia, the extent to which they may be employed, and various regulations respecting them, are specially pointed out in a series of legislative provisions, ${ }^{327}$ which do not deny, but admit, the power of the Crown to command them, subject to such provisions. Under these enactments, the king is enabled in all cases of actual

\footnotetext{
${ }^{319}$ Pitt's Militia Act (1757) 30 Geo 2 c 25. See also Plucknett, n 16, p 125. Maitland, n 9, p 456 'All men between eighteen and fifty [except exempted classes] are liable to serve, or to find substitutes who will serve as privates in the militia. The quota...of men for each county is fixed by statute...This....quota is obtained by ballot.' See also 26 Geo III c 107 and then, in 1802, a military code. See also Keir, n 278 , p 305. ${ }^{320}$ Maitland, $\mathrm{n} 9, \mathrm{p}$ 457. See also Thomson, $\mathrm{n} 281$, pp 421-7. For temporary Acts to impress for the army see, $\mathrm{p} 424$. Ibid, $\mathrm{p} 425$ 'Parliament never brought themselves even seriously to consider the desirability of making service in the army or navy compulsory for all men.'

${ }^{321}$ Bowyer, $\mathrm{n} 8, \mathrm{p} 490$. Troops in Ireland were only by legislation since it was considered out of the realm, as Coke noted, $\mathrm{n} 25$, vol 2, pp 478 commnenting on Magna Carta c 29 (on the words no man exiled) 'the king cannot send any subject of England against his will to serve him out of his realm, for that should be an exile, and he should perdere patriam [lose his country]: no, he cannot be sent against his will into Ireland, to serve the king as his deputy there, because it is out of the realm of England...'.

${ }^{322}$ Maitland refers to war time statutory conscription on a few occasions prior to 1815 . However, these were voluntary (ie imprisoned debtors or convicted criminals being released if they agreed to enlist, see $7 \& 8$ Will c 12 and 1 Anne st 2 c 20 - both were temporary). The only compulsory one was in respect of paupers - ( $2 \& 3$ Anne c 13). See Thomson, n 281, p 297 'Conscription was applied to paupers during the reign of Anne [1702-14] by a number of temporary Acts, which directed the justices of the peace to levy for military service such able-bodied men as neither followed a lawful calling nor possessed means of support. Other Acts, also temporary, granted a discharge to imprisoned debtors who joined the army or navy. Others, again, permitted the Crown to pardon felons convict on condition that they enlisted.' In a fn he noted 'The first Act for the conscription of paupers was 2 and 3 Anne, c 13; the first Act with regard to debtors was 7 and 8 Will III, c 12; the first Act with regard to felons was 1 Anne, stat 2, c. 20.'

${ }^{323}$ Walker, n 204 (militia) 'In 1757, each county had to find a quota and men were to chosen by ballot, but after 1815, voluntary enlistment was substituted, though ballot was not officially suspended until 1865. In 1907, militia units became part of the special reserve. In 1921, the portion of the army reserve previously called the special reserve was called the militia and, when conscription was introduction in 1939, men called up were called militiamen. Since 1950, the term has again been used for a category of reserve forces.' Cf. Maitland, $\mathrm{n} 9$, $\mathrm{p} 458$ (who thought balloting ended in 1832, which seems incorrect since TE May, The Constitutional History of England (1882), vol 1, p 30, who noted that the office of muster master was abolished in 1818, citing Clode, n 168, vol 2, pp 9-10.

${ }^{324}$ See Chitty, $\mathrm{n} 7$.

${ }^{325}$ In a fn Chitty cited Foster, p 158 and the three statutes cited by Dodson in a fn to the $2^{\text {nd }}$ and $3^{\text {rd }}$ eds of Foster's work, viz. Act of 1495 , Act of 1327 (now rep) and Act of 1641 (now rep).

${ }^{326}$ Chitty, n 7, p 46.

${ }^{327} \mathrm{Ibid}, \mathrm{p} 4, \mathrm{n}$ (d) states 'See 43 Geo 3 c 90 (1803), which reduces the preceding statutes into one, and refer to the subsequent statutes'. He also referred to Blackstone, $\mathrm{n} 27$, vol 1, p 412.
} 
invasion, or upon imminent danger thereof, and in all cases of rebellion or insurrection, ${ }^{328}$ the occasion being first communicated to Parliament, if sitting, or if not sitting, declared in Council and notified by proclamation, to order the militia to be embodied; and [HM] may used them, or such proportion of them, and in such manner as [HM] shall in his wisdom necessary, and when drawn out into actual service, they are liable to all the rigours of martial law. But it is expressly enacted by all the statutes on this subject that the militia shall, on no account, be sent out of Great Britain. ${ }^{329}$ (underlining supplied)

Therefore, it is clear that Chitty was referring to the shire militias and to legislation governing the same. Thus, he was referring to a statutory power granted to the Crown. Not to any asserted common law Crown prerogative. However, this important caveat was missed by later legal writers. Chalmers (writing in 1922) stated:

The king has a right to require the personal service of every man able to bear arms in case of a sudden invasion, and the allegiance due from the subject renders it incumbent upon him to assist his sovereign on such occasion (Chitty, p 47) 330

This is incorrect. It was not what Chitty actually said. The sovereign only had such a right pursuant to legislation. Therefore, there is a danger of stating legal propositions too tersely and of quoting prior legal writers out of context, which Chalmers appears to have committed here. As it is, the shire militias were abolished in 1907 (and a new territorial army formed). Thus, all the legislation - and any statutory rights given to the Crown in respect of the same - is now irrelevant.

\section{In conclusion, the statements of Chitty, relating to the militia, are no longer relevant.}

\section{(w) Decline \& Disbandment of the Militia. 1815-1882}

The annual Mutiny Acts were supplanted by an Army Act in 1881 (of 193 sections). This was the first attempt to codify most military law dealing with the professional army. As for the shire militias, a Consolidation Act of 1882 331 took away all the duties and powers of the lord lieutenants in relation to them. Maitland (in writing 1887-8) concluded:

the militia while keeping its name has by slow degrees...become something utterly different from what it was in the seventeenth, even in the eighteenth century. In truth it is very like a second standing army. Owing to the fact that England is an island, we have never taken kindly to compulsory military service; the consequence is that we have two professional armies. The old ballot clauses are still hanging over our heads, but they would be rusty machinery for the present day. The militia is now quite as much under the control of the Crown as is the regular army. ${ }^{332}$ The lord lieutenant has ceased to be a military officer, the militia has now but little to do with any organisation of the county. ${ }^{333}$

However, there was no need for two 'professional armies'. Since 1688, a regular standing army had been established and, by 1815 , enlistment in the shire militias had become voluntary. ${ }^{334}$ The Victorian reform in 1882 was intended to disband the shire militia and have only one professional army. The demise of the shire militia came in 1907. Feilden (1911) stated:

By the 'Territorial and Reserve Forces Act 1907'335 the militia...became extinct and their place was taken by the force now known as the 'Territorials'... This new force... is raised by voluntary enlistment. ${ }^{336}$

The actual position was slightly more complicated than that. Dicey $\left(5^{\text {th }}\right.$ ed, 1948$)$ stated (correctly its asserted) as follows:

The $[1907$ Act, did not repeal the various Militia Acts. Until these Acts were repealed the statutory power of raising the militia, either regular or local, and of forming thereof regiments and corps continued to exist. The militia as long as it existed was in theory a local force levied by [statutory] conscription, but the power of raising it by ballot had been suspended for a considerable time, and the militia was in fact recruited by voluntary enlistment. Embodiment converted the militia into a regular army, but an army which could not be called upon to serve abroad. But the militia was not raised after the reorganisation of the forces consequent upon the passing of the [Act of 1907]. By the Act of 1921 [the Territorial Army and Militia Act 1921] the title of the special reserve, raised under the Act of 1907, was altered to militia. This force had no historical connection with the militia referred to in these notes. The position of

\footnotetext{
${ }^{328}$ See Pitts Militia Act of 1757 , see 15 (t).

${ }^{329}$ Ibid, p 45 .

${ }^{330}$ Chalmers, $\mathrm{n} 11, \mathrm{p} 108$. In the $5^{\text {th }}$ edition, Chalmers cut out the citation to Chitty and stated, p 160 'The king has a right to demand the personal service of every man able to bear arms in case of a sudden invasion, and the tie of allegiance binds the subject to comply with this demand.'

33145 \& 46 Vic c 49.

${ }^{332}$ Meaning that the divergency between the shire militia and the regular army was narrowing.

${ }^{333}$ Maitland, n 9, p 459.

${ }^{334}$ See generally Plucknett, n 16, pp 674-5. Also, Walker, n 204 (impressment).

3357 Ed VII c 9.

${ }^{336}$ Feilden, n 10, p 309.
} 
the militia was affected by the [1907 Act], in two ways, (1) All the units of the general (or regular) militia were either transferred to the army reserve or disbanded. (2) the personal regular militia ceased to exist as such. ${ }^{337}$

In short, the old militia was defunct by 1907, albeit, the term 'militia' was still used in 1921 to refer to what later became the territorial army as we know it today. Wade (in 1931) stated:

Compulsory service, which until recently was probably enforceable for home service only in the now extinct militia... can only be legalised by Parliament. ${ }^{338}$

One would agree with Wade's conclusion since - in both WWI (19814-18) and WW2 (1918-39) - conscription was only effected pursuant to legislation. Thus, in the case of WW2, prior to it, the Military Training Act 1939 made military service compulsory in time of peace. ${ }^{339}$ The National Service (Armed Forces) Act 1939 replaced it and the same was extended. ${ }^{340}$ After WW2, in process of time, there has remained only the regular (standing) armed forces. Also, the territorial army.

\section{(x) Conclusion}

The idea that there is a Crown prerogative existing today to conscript all able-bodied male British subjects ${ }^{341}$ to serve in the army today, is not sustainable, for some simple reasons:

1. Anglo-Saxon Law. There was a compulsory obligation of military service (fyrd fare - army service) one of the trinoda necessitas. It applied to able-bodied freemen (boys over 12). It did not apply to slaves, serfs, women or foreigners. However, post-Conquest this was supplanted by: (a) tenurial service (knight service) as a consequence of holding land (see 2); and (b) the Assize of Arms 1181 (which was extended to serfs in 1272) and the Statute of Westminster 1285 (see 3). Fyrd fare seems not to have been referred to after 1181 and Anglo-Saxon law is not part of English law today. ${ }^{342}$

2. Tenurial Service - Allegiance. William I (1066-87) claimed title to all land in England, The Crown, then, granted land, to subjects on the basis, in some cases, of their performing military service ${ }^{343}$ and paying him allegiance. This was not compulsory service as such ${ }^{344}$ and - in any case - knight service and other military obligations were wholly abolished by legislation in 1660 (save for ceremonial grand and petty sarjeanty). Further any asserted obligation of all subjects to defend the sovereign militarily pursuant to legislation of William I (1066-87) or Henry II (1154-89) ${ }^{345}$ was, also, tenurial since it referred to their fealty to the sovereign as the source of that obligation. ${ }^{346}$

3. Commissions of Array (English Shire Militias). England had no standing army until 1689 (Mutiny Act 1689). However, apart from tenurial service (see 2), shire militias existed.

- Bearing Arms ended 1603. To the extent they were required to bear arms (i.e. to have weapons at home, ready for war) under Anglo-Saxon law, this was superceded by legislation (the Assize of Arms 1181, the Statute of Westminster 1285 and an Act of 1557). These provided for able-bodied men between 15-60 to 'bear arms' (that is, to have weapons of war at home) and to present them at an annual assembly (array) summoned by the sheriff (and, later, the lord lieutenant). This legislation was repealed in 1603 (ending any legal requirement to retain military weapons at home).

- $\quad$ English Shire Militias - Ended 1907 After the Norman Conquest (1066) shire militias continued to exist. However, they became subject to legislation. Thus, any Anglo-Saxon form of shire militias (and their legal

\footnotetext{
${ }^{337}$ Dicey n 15, $5^{\text {th }}$ ed (ed Wade, 1948), pp 295-6. Plucknett, n 16, p 676 that 'This Act...finally submerged this old historic force, which has now ceased to exist...?

${ }^{338}$ Wade, $\mathrm{n} 12$, p 321. In a note he stated: 'This force was disbanded in 1908, its place being taken by the Special Reserve, which in 1921 was renamed the militia.'

${ }^{339}$ Keith, n 60, p 195 'Under it youths between the ages of 20 and 21 normally resident in Great Britain become liable for military training for four years as militiamen, being deemed to have enlisted under the Territorial and Reserve Forces Act 1907.'

${ }^{340}$ Plucknett, n 16, p 677 'The approach of the Second World War brought a remarkable extension of the principle of conscription. The Military Training Act, 1939 (May 25) for the first time made military service compulsory in time of peace. The National Service (Armed Forces) Act, 1939, replaced it (September 3) with a more comprehensive scheme and, as the war proceeded, further legislation introduced 'national service' as the industrial counterpart of military conscription, and eventually these provisions were extended to women as well as to men.' See also Keith, n 60, pp 191-203 for the position of the army from 1907-1940.

${ }^{341}$ But of what lower age? 12 or 15 or 16 (ages for shire militia) or Pitt's Act 1757 (18) or WW1 (18-51) or WW2 (18-41) or national service postwar (17-21)? And what upper age? Today, 60 would be too old. Pitt's Act 1757 lowered it to 50. See also McBain, n 43, p 54.

${ }^{342}$ Keir (but not Foster) sought to find the obligation of subjects to defend the realm in the Anglo-Saxon fyrd,, Keir, n 278 , p 37 'a principle originating in the Anglo-Saxon period, took the form of shire-levies, pressed for service by virtue of the obligation at common law of every subject to bear arms in defence of the realm...' However, this did not cover all subjects, simply all able-bodied freemen aged 12-60 (i.e. no women, slaves, serfs). Probably, it also excluded clerics and judges as well as some others. Further, in practice, for battle only limited numbers of able-bodied men were elected.

${ }^{343}$ The other obligations were spiritual and agricultural (socage, probably, from $s o c$ the plough).

${ }^{344}$ It was on a reciprocal basis, military service (with allegiance to the sovereign) in return for landholding.

${ }^{345}$ This on the basis of an over-reaching allegiance to the sovereign as lord paramount (above any allegiance to a specific lord). However, this was also tenurial.
}

${ }^{346}$ All Norman and subsequent tenure for military service was based on land. 
regulation) was supplanted by the Assize at Arms 1181. Further, any control of shire militias by the Crown, without the consent of Parliament became increasingly restricted viz.

- Statute of Confirmation. The Crown had to pay for any embodiment of the shire militias (to form an army). However, they could not be financed by the Crown raising new taxes (tasks) to pay for them (Statute of Confirmation 1297);

- Fighting Abroad. Shire militias could not be compelled to (including Scotland, ${ }^{347}$ Ireland and Wales pre-1284) due to an Act of 1327 - save in the case of foreign invasion.

- No Compulsion to Provide Men. No subject could be compelled to find men for the shire militias (unless Parliament so provided) due to an Act of 1351 (this did not prevent voluntary enlistment; nor the Crown contracting hiring mercenaries).

- Act of 1641. An Act confirmed that no one could be compelled to serve in the shire militias outside their shire, save in the case of foreign invasion (confirming the Act of 1327).

Also, shire militias (when embodied, which was rare) mainly comprised volunteers anyway, since there was a system (as with the Anglo-Saxons and tenurial military service, see 2) in which men could pay (compound) for another to fight for them. Despite this, shire militias were used illegally by the Crown. Especially, in the reign of Edward II (1307-27), Wars of the Roses (1355-1485) and, after, 1624, by James I (1603-24) and Charles II (1625-49).

In 1662 - some 360 years ago - shire militias were placed on a statutory basis and the Crown never attempted, by any assertion of Crown prerogative, to use them illegally thereafter (or asserted such a prerogative).

With the creation of a standing professional army in 1689, shire militias were rarely embodied. Pitts Act 1757 (like the Act of 1662) confirmed their statutory basis, as did further consolidating legislation. Voluntary enlistment in them occurred after 1815 (i.e. more than 200 years ago), removing any need for (statutory) compulsion. Shire militias was disbanded in 1907, ending any possible Crown prerogative in respect of them. The Territorial Army of today is statutory and has always operated by voluntary enlistment.

- Voluntary Enlistment//Contractual Enlistment. Because of the need for a professional army, until the reign of Henry II (1154-89) sovereigns hired professional foreign mercenaries (especially for wars on the continent). Because the use of such in England was hugely unpopular, from the reign of Edward I (1272-1307) sovereigns hired English subjects to fight for them by way of contract (indenture). Such persons were impressed (that is, paid prest money by the Crown). This was not treated as compulsory military service as such, although a degree of compulsion was used through trickery etc ${ }^{348}$ With the establishment of a professional army in 1689 , rare legislation enabled certain persons to be compulsory enlisted in the professional army. However, after 1815 (more than 200 years ago) enlistment in both the professional army (created 1689) and the shire militias was voluntary.

Thus, there never was a Crown prerogative to compel English subjects to join the army (the shire militia), unless Parliament consented to the same (in which case it was statutory) or by reason of military tenure (which ended in 1660). It was for this very reason that the Crown, pre-1660, resorted to illegal methods. Thus, the statement in Halsbury $\left(1^{\text {st }}\right.$ ed, 1909) and repeated in later editions that:

The Crown may...demand, and is entitled to, the personal services of every man capable of bearing arms [i.e. any able-bodied man] in case of sudden invasion or dangerous rebellion, but except on such occasions it has no power to compel enlistment.

is incorrect. It was based on Broadfoot (1743).

- However, in that case Sir Michael Foster (obiter) could find no case nor statutory authority to argue for such. Thus, he asserted there was a Crown prerogative based on 'lex salus' - albeit, such has never been a principle of English law (the common law or statute);

- Further, Foster overlooked an Act of 1662 which placed the shire militia on a statutory basis and, thus, superceded any Crown prerogative at common law to impose army conscription (even if there was one).

- Moreover, the judgment in Broadfoot (1743) was superceded by Pitts Militia Act 1757 which confirmed the statutory basis and, in any case, the shire militias were disbanded in 1907.

Thus, as Wade noted (in 1931)(putting a best case scenario) ${ }^{349}$

Compulsory service, which until recently was probably enforceable for home service only in the now extinct [shire] militia... can only be legalised by Parliament. (italics supplied)

\footnotetext{
${ }^{347}$ Scots shire militias were created by statute in 1797 (more than 220 years ago), see n 306.

${ }^{348}$ The press gangs (and their reputation) were mainly the result of naval impressments since, after 1668, compulsory military service was by statute and rarely required. It was not practiced after 1815 anyway.

${ }^{349}$ Wade said 'probably', but did not consider the matter in detail.
} 
As it is, statutory conscription was used in WW1 and WW2. It may, also, be noted that forcible conscription pursuant to any Crown prerogative was (and is) not the same as an asserted Crown prerogative to require the military to aid the civil power (i.e. the police). ${ }^{350}$

- Modern Warfare. Finally, it is most unlikely - given modern warfare - that it would be useful for the Crown - after 350 years to seek to compel - without the agreement of Parliament - all able-bodied male subjects join the army, for war. Such would be very expensive, require huge administration and the swift training (and arming) of great numbers of men who would, in any case, be of little use against the missiles, tanks, drones etc of a trained army of an enemy. Further, if such was required, legislation is the only appropriate means. ${ }^{351}$ Also, prior to this, it is more likely that the government would call up all reservists, ex military men (and women) and police;

- $\quad$ Problems with Age, Exemptions, Punishment. Also, how would it work if the Crown suddenly sent call up papers to all UK men demanding they appear at a designated place, for conscription? How could they fix the age limit, since there is no statutory basis? Assuming they fixed it at the old shire militia limit in Pitt's Act 1757 of 18-50, they could only demand the attendance of men (not women) who were able-bodied and (one assumes) not exempt from the old shire militias (which, included, by the end clergy, judges etc). And, what would be the punishment if those summoned refused to appear? There is no legislation involved (thus, no statutory provision and contempt of statute could not be relied on - in the absence of a punishment not otherwise provided in legislation). And, a person refusing to attend does not commit high treason under the Treason Act 1351. Nor is it likely the old common law offence of contempt of the sovereign could be invoked, with a punishment at the discretion of the court. ${ }^{352}$ Further, even if the Crown attempted this, the Bill of Rights 1688 prevents the raising of a standing army in peace time without the consent of Parliament. Thus, any Crown prerogative could only be asserted in war time. Further, could these conscripts to fight abroad? (although the Acts of 1327 and 1641 have been repealed). In short, any attempt without legislation could (perhaps) justly be seen as a return to the reign of Charles I and 1642.

As it is, the history of illegal conscription by the Crown in times past is grim and it, usually, ended in disaster. Indeed, had English law been more clear in that war could only be waged by the Crown with the consent of Parliament (which Parliament sought to do on a number of occasions) ${ }^{353}$ it is likely that many ruinous wars and huge loss of life could have been spared. ${ }^{354}$

In conclusion, there is no Crown prerogative to conscript able-bodied males for army service in the case of war - including in the case of foreign invasion or civil insurrection. Conscription can only be effected today by legislation.

\section{CROWN PREROGATIVE - CERTIFICATION OF STATE OF WAR etc}

(a) Introduction

A previous article has noted the practice of the Foreign, Commonwealth and Development Office (FCDO) in certifying the status of foreign states. ${ }^{355}$ When this practice arose is unclear (it will have been fairly recent). Also, it cannot really be called a Crown prerogative - since the sovereign appears never to have adopted such a practice. Neither Blackstone (1765-9) nor Chitty (1820) mentioned such in their works. Nor, the first edition of Halsbury (in 1907). ${ }^{356}$ De Smith (in 1998) stated:

By virtue of the prerogative, the Crown is...entitled to determine conclusively a range of other matters... 1 . Whether a state of war exists between [HM] and a foreign country. Thus, in one case, soon after the end of armed hostilities in [WW2], the Crown was still detaining and wished to deport a German national as an enemy alien; he brought an application for a writ of habeas corpus, contending that the state of war was at an end and that in any case Germany no longer existed as a State; the court accepted as conclusive a certificate entered by a [SS] contradicting these contents. 357

There also seems to have been a practice of indicating, in war time, whether a state was a neutral state or not.

(b) Conclusion

As with a FCDO certificate it would seem useful to align the same, in war time, with any certification as to whether: (i) a state of war exists; and (ii) a state is a neutral state or not. Thus, it is suggested that similar legislative wording

\footnotetext{
${ }^{350}$ Keith, n 60, vol 2, p 199 referred to the latter in 1939 'the common law obligation of every soldier, as of every British subject, to aid the civil power in case of need...'?

${ }^{351}$ Also, prior to this, it is more likely that the government would call up all reservists, ex-military men (and women) and police first.

${ }^{352}$ See GS McBain, Abolishing some Obsolete common Law Crimes (2009), p 103.

${ }^{353}$ By the Confirmation of the Charters 1297 and the Acts of 1327 and 1351.

${ }^{354}$ The downfall of Charles I (1625-49) and James II (1685-8) was directly linked to their seeking to raise armies contrary to the will of Parliament. So too, Edward II (1307-27) for his conscript armies to Scotland (leading to the loss of Bannockburn in 1314) and France. All three paid the price.

${ }^{355}$ See McBain (BTFRA), n 3.

${ }^{356}$ Halsbury, n 6, $1^{\text {st }}$ ed (1909), n 6, vols 6 \& 7.

${ }^{357}$ De Smith (in 1998), n 19, p 151 referring to $R v$ Bottrill, ex p Kuechenmeister [1947] KB 41.
} 
be provided for all three and that any (asserted) Crown prerogative, be abolished. The FCDO should be responsible for issuing such certificates.

\section{In conclusion, an Armed Forces Act should deal with certification by the FCDO.}

\section{CROWN PREROGATIVE - ANGARY (REQUISITION OF NEUTRALS PROPERTY)}

This concept is, probably, not a Crown prerogative as such. Rather, it is more a principle developed under the international law with regard to war. No mention appears to have been made of it in Blackstone (1765-9) or Chitty (1820). Walker noted that that it had an older meaning ${ }^{358}$ and a newer one; the latter only now being relevant. He stated in respect of the latter:

The modern right of angary is the right of belligerents to destroy or take up and use in case of absolute necessity, for the purpose of offence or defence, neutral property on their territory or on enemy territory. There can be no requisition on the open sea. It is usually justified as an exercise of the power of a sovereign state. It does not extend to compelling neutral individuals to render services. There is a duty to pay compensation for damage done. It is comparable to the power of states to requisition property of their own nationals, or to seize enemy property on their territory. ${ }^{359}$

It would be useful for an Armed Forces Act to make provision for this and to abolish any Crown prerogative, so that the matter is clarified in legislation.

\section{REMAINING LEGISLATION}

It has been previously noted that all Armed Forces legislation should be consolidated into one Act (see Appendix A). This would leave a few pieces of legislation which indirectly refers to military matters. It may be an idea to place material relating to:

(a) War Damage (to the extent not spent); and

(b) Munitions,

in Appendices to an Armed Forces Act. Also, to consolidate material relating to emergencies into a Civil Contingencies Act and any old import and export legislation (to the extent not spent) into the Export Control Act 2002.

In conclusion, an Armed Forces Act should consolidate all legislation relating to the same (save where SI's would be more appropriate).

\section{CONCLUSION}

The conclusion may be stated shortly:

- $\quad$ Consolidate Legislation. All existing legislation relating to the armed forces (some 106 Acts, see Appendix A) should be consolidated into one Armed Forces Act or Code (AFC). This would not be difficult since the Armed Forces Act 2006 is a good basis. Also, as noted, much material could be placed in a SI;

- $\quad$ Abolish Obsolete Crown Military Prerogatives. For the reasons given in this article it is asserted the following are obsolete, being superceded by legislation: (a) exporting UK military equipment in war time; (b) trading with the enemy in war time; (c) conscripting British subjects for the army in war time. See Appendix B.

- $\quad$ Place in Legislation other Crown Military Prerogatives. The following should be placed in an Armed Forces Act in order to clarify the same, with any Crown prerogative being abolished: (a) making (i.e. waging) war; (b) declaring war; (c) making peace; (d) declaring peace; (e) the management, and operation, of the UK's armed forces (also, the territorial army); (f) the management, and operation, of the UK's military installations; (g) military operations abroad (including peace keeping operations). See Appendix B.

Is any of the above contentious? One would suggest that consolidating legislation and abolishing obsolete material would not be. Nor placing material in legislation. Nor the content of the same save (possibly) the need for the consent (resolution) of Parliament to make war. Further, generally, it seems well accepted that Crown prerogatives have had their day and that they should - where required - become statutory. ${ }^{360}$ And, there is no doubt that Parliament, by statute, can abolish Crown prerogatives. ${ }^{361}$ As it is, as Munro noted (in 1999) 'the prerogative is imperfectly subject to parliamentary control' ${ }^{362}$ and that:

\footnotetext{
${ }^{358}$ Walker (angary) n 204, '(or ius angariae, from angaria) 'A post system, hence compulsory right of transport, was formerly the right of belligerents under international law to lay embargo on and seize neutral ships in their harbours and compel them and their crews to transport troops, munitions and provisions on payment of freight. This right was sometimes excluded by treaty and fell into disuse during the eighteenth century.' See also Halsbury, Laws ( $5^{\text {th }}$ ed), n 6, vol 20, para 547, n 1 . ${ }^{359}$ Ibid.

${ }^{360}$ Munro, n 20, p 271 'By comparison with the high drama of the seventeenth century, however, subsequent moves to abolish or control prerogatives powers by statute have been uncontroversial and infrequent.'

${ }^{361}$ Ibid, p 272 'There is no doubt that Parliament may expressly abolish or restrict the prerogative...Parliament may abolish or restrict or preserve aspects of the prerogative, as it chooses.'

${ }^{362}$ Ibid, p 278.
} 
there would be several advantages in replacing the existing prerogatives with statutory powers, such as the government more usually acts under. If that were done, the purposes and extent of the powers could be clearly set out, whereas much of the law concerning the prerogative is obscure and derived from ancient precedents. Supervision of the exercise of the powers could be more efficiently carried out in Parliament and by the courts. ${ }^{363}$

One would (wholly) agree. As it is, various articles - and this article - have indicated that it is perfectly possible to consolidate all Crown prerogatives into the following pieces of legislation:
1. Crown Act
2. Parliament Act
3. Courts Act
4. Government Act
5. British Territories and Foreign Relations Act
6. Armed Forces Act

Further, it is asserted that all of 1, 2 and 5 can be consolidated into a Constitution Act of some 100 sections. Then, at last, UK citizens and most lawyers (and civil servants) will actually know what their constitution is and how it operates. This would also be very useful for Commonwealth countries. Surely, a good thing? Thus, a further article will indicate how a Constitution Act would look, if all Crown prerogatives were abolished and 1,2 and 5 (relating to the British Territories) consolidated into the same.

\section{Appendix A-Consolidation of Armed Forces Legislation}

The following legislation (much of it piecemeal, it may be found in Halsbury, Statutes, vol 3) could be consolidated into one Armed Forces Code of c. 750 sections. The merit of such would be: (a) all relevant legislative material would be in one place; (b) common definitions; (c) excision of transitional material; also, references to repealed matter; (d) user friendly; (e) up-to-date.

\section{No of Sections}

\section{(a) Military Land}

\begin{tabular}{|c|c|c|}
\hline 1842 & Defence Act & 28 \\
\hline 1854 & Defence Act & 3 \\
\hline 1855 & Ordnance Board Transfer Act & 2 \\
\hline 1859 & Defence Act & 3 \\
\hline 1860 & Defence Act & 21 \\
\hline 1864 & Defence Act Amendment Act & 3 \\
\hline 1865 & Defence Act (amends 1860 Act) & 1 \\
\hline 1865 & Defence Acts Amendment Act (deals with 1842 and 1860 Acts) & 1 \\
\hline 1873 & Militia (Lands and Buildings) Act (deals with 1842 and 1869 Acts) & 1 \\
\hline 1892 & Military Lands Act & 19 \\
\hline 1897 & Military Lands Act (refers to 1892 Act) & 1 \\
\hline 1900 & Military Lands Act & 4 \\
\hline 1903 & Military Lands Act (refers to $1892 \mathrm{Act}$ ) & 1 \\
\hline 1916 & Defence of the Realm (Acquisition of Lands) Act & 10 \\
\hline 1920 & Defence of the Realm (Acquisition of Lands) Act & 5 \\
\hline 1945 & Requisitioned Land and War Works Act & 21 \\
\hline 1948 & Requisitioned Land and War Works Act & 9 \\
\hline 1958 & Land Powers (Defence) Act & 4 Total: 127 \\
\hline
\end{tabular}

Most of this material relates to the requisition of land for military purposes. It should be consolidated (much is also obsolete).

\section{(b) Armed Forces, Reserves, Visting Forces, Military Police}

1662 City of London Militia Act 1

$1820 \quad$ Militia (City of London) Act 8

$1862 \quad$ Officers Commissions Act 2

$1890 \quad$ London Council (General Powers) Act (s 16 relates to drills) 1

$1894 \quad$ Uniforms Act 3

$1917 \quad$ Air Force (Constitution) Act 4

${ }^{363}$ Ibid, p 291. 


$\begin{array}{ll}\text { Visiting Forces (British Commonwealth) Act } & 3 \\ \text { Reserve and Auxiliary Forces (Protection of Civil Interests) Act } & 49 \\ \text { Visiting Forces Act } & 18 \\ \text { Manoeuvres Act } & 1 \\ \text { Armed Forces Act (spent) } & 1 \\ \text { Armed Forces Act (relates to Greenwich hospital) } & 2 \\ \text { Armed Forces Act (s 26 relates to pensions) } & 19 \\ \text { Reserve Forces (Safeguard of Employment) Act } & 15 \\ \text { Ministry of Defence Police Act } & 10 \\ \text { Armed Forces Act } & 130 \\ \text { Reserve Forces Act } & 4 \\ \text { Armed Forces Act (s 30 relates to Greenwich hospital) } & 4 \\ \text { Armed Forces Act } & 6 \\ \text { Armed Forces Act } & 380 \\ \text { Armed Forces Act } & 3 \\ \text { Citizenship (Armed Forces) Act (amendments) } & 3 \\ \text { Armed Forces Act } & 1\end{array}$

The key Act is the 2006 Act (which is well drafted). It should be re-enacted, absorbing these other Acts (much could be put in Schedules). The effect would be a new (comprehensive) Armed Forces Code.

\section{(c) $\underline{\text { Pensions }}$}

$\begin{array}{lll}1865 & \text { Naval and Marine Pay and Pensions Act } & 5 \\ 1884 & \text { Naval Pensions Act } & 1 \\ 1884 & \text { Pensions and Yeomanry Pay Act } & 4 \\ 1914 & \text { Army Pensions Act 1914 (applies pre-1981, obs) } & 3 \\ 1917 & \text { Naval and Military War Pensions etc (Administrative Expenses) Act } & 1 \\ 1918 & \text { War Pensions (Administrative Provisions) Act } & 4 \\ 1919 & \text { War Pensions (Administrative Provisions) Act } & 6 \\ 1920 & \text { War Pensions Act } & 3 \\ 1921 & \text { Admiralty Pensions Act } & 6 \\ 1921 & \text { War Pensions Act } & 6 \\ 1939 & \text { Pensions (Navy, Army, Air Force and Mercantile Marine) Act } & 9 \\ 1942 & \text { Pensions (Mercantile Marine) Act } & 1 \\ 1942 & \text { War Orphans Act 1942 } & 2 \\ 1977 & \text { Social Security (Misc Provs) Act } & 9 \\ 1986 & \text { Protection of Military Pensions Act } & 9 \\ 1989 & \text { Social Security Act (s 25 relates to pensions) } & 1 \\ 2004 & \text { Armed Forces (Pensions and Compensation) Act } & 67\end{array}$

All this material should be put into a Statutory Instrument (of c. 20 sections at most, much is obsolete). It does not need to be in general legislation.

\section{(d) $\underline{\text { Prize }}$}

$\begin{array}{lll}1864 & \text { Naval Prize Act } & 25 \\ 1894 & \text { Prize Courts Act } & 3 \\ 1914 & \text { Prize Courts (Procedure) Act } & 1 \\ 1915 & \text { Prize Courts Act } & 3 \\ 1916 & \text { Naval Prize (Procedure) Act } & 1 \\ 1939 & \text { Prize Act } & 4 \\ 1944 & \text { Prize Salvage Act } & 2 \text { Total: } 39\end{array}$

Consideration should be given to abolishing the law of prize and bounty. Thus, this legislation would be repealed.

\section{(e) $\underline{\text { Wills }}$}




$\begin{array}{llc}1865 & \text { Navy and Marines (Property of Deceased) Act } & 18 \\ 1889 & \text { Revenue Act (s 30 amends } 1865 \text { Act) } & 1 \\ 1918 & \text { Wills (Soldiers and Sailors) Act } & 4 \\ 1930 & \text { Navy and Marines (Wills) Act } & \\ 1939 & \text { Navy and Marines (Wills) Act } & \text { Total: } 23 \\ 1953 & \text { Navy and Marines (Wills) Act } & \end{array}$

The Acts in italics were repealed save for wills presently being dealt with under them (of which there are now none and, thus, they are spent) with the result that the 1953 Act may be repealed as well. This material should be left to be inserted in a new Wills Act.

\section{(f) Greenwich \& Chelsea Hospitals, Imperial War Museum, War Graves}

$\begin{array}{lll}1826 & \text { Chelsea and Kilmainham Hospital } & 10 \\ 1865 & \text { Greenwich Hospital Act } & 21 \\ 1869 & \text { Greenwich Hospital Act } & 6 \\ 1872 & \text { Greenwich Hospital Act } & 3 \\ 1876 & \text { Chelsea Hospital Act } & 1 \\ 1883 & \text { Greenwich Hospital Act } & 4 \\ 1885 & \text { Greenwich Hospital Act } & 2 \\ 1920 & \text { Imperial War Museum Act } & 2 \\ 1926 & \text { Imperial War Graves Endowment Fund Act } & 5 \\ 1942 & \text { Greenwich Hospital Act } & 2 \\ 1955 & \text { Imperial War Museum Act } & 2 \\ 1967 & \text { Greenwich Hospital Act } & 2 \\ & \text { Greenwich Hospital Act } & 2\end{array}$

This material should be modernised and put in a Schedule to the AFC 2021.

\section{(g) Court Martial}

$\begin{array}{lll}1951 & \text { Court Martial (Appeals) Act } & 8 \\ 1968 & \text { Court Martial Appeals Act } & 68 \text { Total: } 76\end{array}$

Consideration should be given to merging this court with the Court of Appeal. If not, it should be placed in a AFC.

(h) Others

$\begin{array}{lll}1864 & \text { Naval Agency and Distribution Act } & 25 \\ 1879 & \text { Registration of Births, Deaths and Marriages (Army) Act } & 2 \\ 1893 & \text { Debts (Deceased Servicemen etc) Act [Regimental Debts Act] } & 26 \\ 1916 & \text { 'Anzac' (Restriction on Trade Use of Word) Act } & 1 \\ 1935 & \text { Regimental Charitable Funds Act } & 2 \\ 1939 & \text { Import, Export and Customs Powers (Defence) Act } & 4 \\ 1949 & \text { Armed Forces (Housing Loans) Act } & 1 \\ 1950 & \text { Royal Patriotic Fund Corporation Act (refers to 1893 Act above) } & 1 \\ 1955 & \text { Revision of the Army and Air Force (Transitional Provisions) Acts (amends) } & 2 \\ 1958 & \text { Defence Contracts Act } & 6 \\ 1958 & \text { Armed Forces (Housing Loans) Act } & 1 \\ 1964 & \text { Defence (Transfer of Functions) Act } & 2 \\ 1965 & \text { Armed Forces (Housing Loans) Act } & 1 \\ 1986 & \text { Protection of Military Remains Act } & 9 \\ 2014 & \text { Defence Reform Act } & 48^{364} \\ 2015 & \text { Armed Forces (Services Complaints and Financial Assistance) Act } & 3 \\ 2018 & \text { Armed Forces (Flexible Working) Act (amends) } & 1 \text { Total: } 132\end{array}$

This should be placed (if still needed) in the AFC 2021.

In conclusion, all the above material should be consolidated into 2 Acts (Codes). The material referred to below is also contained in Halsbury Statutes, vol 3 and it makes (at times) cross reference to military matters/legislation (which should be amended).

${ }^{364}$ This includes material on the Reserve Forces and Military Police which should go into (b). 


\section{(a) Emergencies}

$\begin{array}{ll}1939 & \text { Patents, Designs, Copyright and Trade Marks (Emergency) Act } \\ 1947 & \text { Emergency Laws (Misc Provs) Act } \\ 1953 & \text { Emergency Laws (Misc Provs) Act } \\ 1959 & \text { Emergency Laws (Repeal) Act } \\ 1964 & \text { Emergency Powers Act } \\ 1964 & \text { Emergency Laws (Re-enactment and Repeal) Act } \\ 2004 & \text { Civil Contingencies Act } \\ 2006 & \text { Emergency Workers Obstruction Act }{ }^{365} \\ \text { (b) War Damage } & \\ 1939 & \text { Compensation (Defence) Act } \\ 1939 & \text { Liability for War Damage (Misc Provs) Act 1939 } \\ 1945 & \text { Limitation (Enemies and War Prisoners) Act } \\ 1949 & \text { Distribution of German Enemy Property Act (spent) } \\ 1952 & \text { Distribution of German Enemy Property Act (amends 1949 Act) } \\ 1953 & \text { Enemy Property Act } \\ 1965 & \text { War Damage Act } \\ \text { (c) Import \& Export Controls } \\ 1939 & \text { Import, Export and Customs Powers (Defence) Act } \\ 1990 & \text { Import Export Control Act } \\ 2002 & \text { Export Control Act } \\ \text { (d) } \text { Munitions } & \text { Landmines Act } \\ 1998 & \text { Cluster Munitions (Prohibition) Act } \\ 2010 & \\ \text { (e) Others } & \\ 1956 & \text { Underground Works (London) Act } \\ \end{array}$

\section{Appendix B - ARMED FORCES ACT}

Part I: Responsibility for Defence

1. Ministry of Defence (MOD)

2. MOD accountable to Parliament

\section{Part 2: Armed Forces (AF) and Territorial Army (TA)}

3. $\mathrm{AF}$ and $\mathrm{TA}$

4. Standing AF

5. Commander-in-Chief

6. Employment

7. Armed Intervention Abroad

\section{Part 3: War}

8. War

9. Declaration of War

Part 4: War Time Events

10.Trading with the Enemy

11. Angary

12. FCDO Certificate

13. Prize and Booty

\section{Part 5: Peace}

14. Peace

15. Declaration of Peace

\footnotetext{
${ }^{365}$ These should be, to the extent not spent, consolidated into the 2004 Act.
} 


\section{Part 6: General}

16. Embargo or Blockade

17. Requisition of Ships

18. Requisition of Real Property by MOD

19. Obsolete Crown Prerogatives

20. Interpretation

21. Repeals and Application

\section{Ministry of Defence (MOD)}

(1) The MOD is responsible for all matters relating to the military defence of the:
(a) UK; and the
(b) British Territories

In particular, for the matters referred to in ss 1-11 and 16-18, save where legislation provides otherwise.

(2) Any Crown prerogative in respect of (1) is abolished.

\section{MOD Accountable to Parliament}

(1) The MOD is accountable to Parliament.

(2) Any accountability of the MOD to the Crown is abolished.

\section{3. $\underline{\mathrm{AF} \text { and TA }}$}

(1) The MOD is responsible for the:
(a) command;
(b) management;
(c) control;
(d) administration;
(e) regulation;
(f) operation;
(g) deployment;
(h) employment, and
(i) discipline

of the $\mathrm{AF}$ and the $\mathrm{TA}$ in the

(i) UK;

(ii) British Territories; and

(iii) abroad

save where legislation provides otherwise.

(2) Section 3(1)(a)-(g) includes reference to all:
(a) Military Land;
(b) Military Installations; and
(c) Military Equipment,

save where legislation provides otherwise.

(3) Any Crown prerogative in respect of (1) and (2) is abolished.

\section{Standing AF}

(1) The AF shall remain in existence during peace time, ${ }^{366}$ unless Parliament resolves otherwise.

(2) Any legal requirement to renew, annually or otherwise:

(a) the existence of any legislation governing the $\mathrm{AF}$;

(b) is abolished

(3) Any Crown prerogative in respect of (1) is abolished.

\section{Commander-in-Chief of AF}

(1) The sovereign is, ex officio, titular commander-in-chief of the AF.

(2) Save for (1), no person may hold:

(a) any ceremonial rank in the $\mathrm{AF}$ or $\mathrm{TA}$,

${ }^{366}$ The Bill of Rights 1688 only referred to the position of a standing army in peace time. 
(b) including any member of the Royal Family. ${ }^{367}$

\section{Employment}

(1) Employment in the AF and TA may only be made by:

(a) voluntary enlistment; or

(b) legislation.

(2) Any Crown prerogative in respect of (1) is abolished, including any power to:

(a) compulsory require any person

(b) to serve in the AF.

\section{Armed Intervention Abroad}

(1) Save in the case of (2), the AF may not engage in any:

(a) military intervention abroad

(b) without a resolution of Parliament.

(2) 'military intervention' includes any peacekeeping exercise.

(3) In the case of a National Emergency, a resolution of the Cabinet is sufficient.

8. War

(1) Save in the case of (2), the AF may not make:
(a) war
(b) without a resolution of Parliament.

(2) In the case of a National Emergency affecting Parliament, a resolution of the Cabinet is sufficient.

(3) In the case of a National Emergency affecting both Parliament and the Cabinet, war may be declared by the PM.

(4) Any prerogative of the Crown in respect of (1) is abolished.

\section{Declaration of War}

(1) Save in the case of (2), war shall be declared by:

(a) an announcement by the PM in Parliament; or

(b) in a SI.

(2) No declaration of war is required in the case of a National Emergency.

(3) A SI may set out the date, and time, when war shall take effect (or when it took effect).

(4) Any prerogative of the Crown in respect of (1) is abolished

10. Trading with the Enemy

(1) Appendix 1 shall apply.

\section{Angary}

(1) The MOD, in war time, may:

(a) requisition any real property

(b) in the UK or the British Territories or enemy territory

(c) which belongs to a neutral person (whether legal or natural)

(d) for military purposes

(e) on payment of reasonable compensation

(f) which is payable at the end of the war.

(2) Any Crown prerogative in respect of (1) is abolished.

\section{FCDO Certificate}

(1) The FCDO shall issue a certificate in the circumstances in (2), if required by a UK court of law:
(a) which shall be conclusive of the same
(b) for all legal purposes
(c) save in the case of manifest error.

(2) The certificate shall indicate whether a:

(a) war exists between the UK and another state(s); or a

(b) a state is a neutral state or not.

(3) The certificate shall be signed by the:

\footnotetext{
${ }^{367}$ See also McBain, n 1 (Crown Act), p 73. This material could be in that Act, or an Armed Forces Act. Probably, the latter is better.
} 
(a) Foreign Minister (or any designate); or the

(b) head of the FCDO (or any designate).

(5) Any Crown prerogative to issue a certificate in (1) is abolished.

13. Prize and Booty

(1) Any Crown prerogative, in war time, to take:

(a) prize; or

(b) booty (bounty), ${ }^{368}$

is abolished.

(2) Title to any enemy Military Equipment captured in war time shall, on capture, forthwith pass to the MOD and it may be:
(a) destroyed
(b) scrapped
(c) disabled; or
(d) otherwise dealt with by the MOD,

without payment of compensation.

\section{Peace}

(1) Peace shall be made by means of:
(a) a peace treaty; or
(b) other agreement.

(2) Any prerogative of the Crown in respect of (1) is abolished

\section{Declaration of Peace}

(1) Peace shall be declared by:

(a) an announcement by the PM in Parliament; or

(b) in a SI

(2) A SI may set out the date, and time, when peace shall take effect (or when it took effect).

(3) Any prerogative of the Crown in respect of (1) is abolished.

\section{Embargo or Blockade ${ }^{369}$}

(1) In peace time, the MOD may not impose an embargo or a blockade on:

(a) shipping

(b) without a resolution of Parliament.

(2) In war time, the MOD may impose a blockade, or an embargo, on:

(a) enemy ships; or

(b) neutral ships carrying enemy Military Equipment or goods.

(3) Any Crown prerogative in respect of (1) and (2) is abolished.

\section{Requisition of Ships}

(1) The MOD, in war time or pursuant to the Civil Contingencies Act $2004,{ }^{370}$ may:

(a) temporarily requisition any UK or BOT registered ship

(c) on payment of reasonable compensation.

(2) Any Crown prerogative in respect of (1) is abolished. ${ }^{371}$

\section{Requisition of Real Property by MOD}

(1) Appendix 2 shall apply.

(2) Any Crown prerogative, whether in peace time or war time, to requisition for military purposes:

(a) any real property in the

(b) UK or the British Territories,

\footnotetext{
${ }^{368}$ Prize and booty referred to military equipment. Not to any real property or any attachment thereto (i.e. buildings, installations etc). See also McBain, $\mathrm{n}$ (Crown Act), p 73. This material could be in that Act, or an Armed Forces Act. Probably, the latter is better ${ }^{369}$ See also McBain, $\mathrm{n} 1$ (Crown Act), p 74. This material could be in that Act, or an Armed Forces Act. Probably, the latter is better.

${ }^{370}$ Alternatively, 'in the case of any emergency'.

${ }^{371}$ Ibid.
} 
is abolished. ${ }^{372}$

\section{Obsolete Crown Prerogatives}

(1) The following are abolished, any Crown prerogative (including any franchise) to:

(a) billet any member of the AF;

(b) impose martial law (including the jurisdiction of courts martial) on civilians;

(c) issue any letter of marque and reprisal;

(d) dig for saltpetre (to make gunpowder);

(e) enter private land to dig for saltpetre;

(f) castellate (that is, to build a castle or fortified residence);

(g) erect military fortifications on private land;

(h) impose a toll for murage (to build city or town defensive walls);

(i) prohibit the export of any Military Equipment.

20. Interpretation

(1) In this Act:

'AF' means the (a) army; (b) navy; (c) air force; (d) any special or other military forces; 'BOT' means British Overseas Territory;

'British Domestic Territories' means the Channel Islands and the Isle of Man;

'British Territories' means the British Domestic Territories and BOT;

'FCDO' means the Foreign Commonwealth and Development Office;

'Military' means the MOD, AF and TA collectively;

'MOD' means the Ministry of Defence;

'Royal Family' means ${ }^{373}$

'SI' refers to a statutory instrument;

' $\mathrm{TA}$ ' means the territorial army;

'UK' means the United Kingdom.

(2) In this Act reference to the:

(a) 'Military Land' means any land used for any military purpose by the Military;

(b) 'Military Equipment' means any equipment of whatever nature used for any military purpose by the Military;

(c) 'Military Installations' means any building of whatever nature used for any military purpose by the Military;

(d) 'National Emergency' means any:

(a) first strike, or pre-emptive military attack, on the UK;

(b) military act which renders Parliament (or the Cabinet, where applicable) inoperative in any way such that the same cannot direct an immediate and full response in the circumstances.

\section{Repeals and Application}

(1) The legislation referred to in Appendix 3 is repealed.

(4) This Act extends to the:

(a) UK; and to the

(b) British Territories.

Appendix 1 - [This will set out the Trading with the Enemy Act 1939 as modernised]

Appendix 2 - [This will set out, in an appendix, MOD legislation relating to land, see Appendix A, (a)]

Appendix 3 - [Repeals]

Settlement Act 1700, s 3

Bill of Rights, art 3

Naval Prize Act 1864

Prize Courts Act 1894

Prize Courts (Procedure) Act 1914

Prize Courts Act 1915

372 Ibid.

${ }^{373}$ The definition depends on whether the royal family is downsized. 
Naval Prize (Procedure) Act 1916

Prize Act 1939

Prize Salvage Act 1944

\section{Appendix C-Texts on Military Law}

This list seeks to list texts on English military law. A more extensive list may be found in Sweet and Maxwell, A Legal Bibliography of the British Commonwealth (1955-7, 2 vols). ${ }^{374}$

\section{Texts from Anglo-Saxon Times - 1500}

Anglo-Saxon law contains virtually nothing on military matters. The standard texts on Anglo-Saxon dooms (laws) from c. 616-1066 (with modern translation) are:

- $\quad$ FL Attenborough (ed), The Laws of the Earliest English Kings (1922, rep 1963);

- $\quad$ AJ Robertson, The Laws of the Kings of England from Edmund [921-46 AD] to Henry I (1925).

The principal earliest English legal texts in the period 1189-1250 are the following (these editions have the most up-to-date translations):

- $\quad$ Glanvill (ed GDG Hall), The Treatise on the Laws and Customs of the Realm of England (Nelson, 1965) (c. 1189);

- $\quad$ H Bracton (trans Thorne), On the Law and Customs of England c. 1240 (Cambridge UP, 1968-76, 4 vols) (also online);

- $\quad$ Britton (c. 1290). Translation with notes by FM Nichols (John Byrne, 1901) (also online);

- $\quad$ Fleta (c. 1290). Selden Society reports ('SS') (also online).

These texts, also, contain virtually nothing on military matters. Holdsworth, History of English Law, asserted that the earliest work on English law was an Abridgment of English Military Discipline (1798) (see 4). ${ }^{375}$ However, there were various Ordinances on military matters published prior to this, as well as Alberti Gentili, On the Law of War (1588, De Jure Belli)(see 3).

\section{Texts relating to Military Law: pre-1500}

Specific legislation on military matters - also called, at various times, the 'law of arms', the 'law martial', 'martial law' and 'military law' include:

- $\quad$ Richard I [1189-99], Charter to all his Men going by Sea to Jerusalem [c. 1189];

- $\quad$ Richard II [1377-99], The Statutes, Ordinances and Customs to be observed in the Army (c. 1385);

- $\quad$ Henry V [1413-22], De Re Militari (c. 1415-21);

- Ordinances of War c.1487 of Henry VII [1485-1509];

- Certain Statutes and Ordinances of War...ordained by Henry VII [1485-1509] (1492);

- $\quad \mathrm{G}$ da Legnano, Tractatus de Bello de Represaliis et de Duello (written c. 1390). ${ }^{376}$

Legal texts on early military law include:

- JM Collins, Martial Law and English Laws c 1500-1700 (2016);

- A Curry, The Military Ordinances of Henry V: Texts and Contexts (2008); ${ }^{377}$

- $\quad$ IJ Sanders, Feudal Military Service in England (1956);

- $\quad$ GS McBain, Abolishing Obsolete Crown Prerogatives relating to Martial Law, Conscription and Billeting. ${ }^{378}$ ('McBain, Martial Law');

- $\quad$ AH Noyes, The Military Obligation in Medieval England (1930).

\section{Texts relating to Military Law: $1500-1600$}

Specific legislation on military matters include:

- $\quad$ Statutes and Ordinances of Wars made, ordained etc by Henry VIII [1509-47] (1513);

- $\quad$ Statutes and Ordinances for War (1544);

- Law and Ordinances set down by the Earl of Leicester the Queen's Majesty's Lieutenant and Captain General of her army and force in the Low Countries (1586). ${ }^{379}$

Also,

\footnotetext{
${ }^{374}$ Sweet and Maxwell, A Bibliography of the British Commonwealth (1955-7, 2 vols). Volume 1 lists texts up to 1801, vol 2 up to 1954.

${ }^{375}$ W Holdsworth, History of English Law, vol 5, p 612.

${ }^{376}$ Translated by JL Brierly (OUP, 1917, first English trans). This has been reprinted by the Law Book Exchange. Giovanni da Legnano (1320-

83) was a canon lawyer at the University of Bologna.

${ }^{377}$ This comprises a chapter in Essays in Honour of Michael Prestwich (2008).

${ }^{378}$ International Law Research (2012), vol 1, no 1, pp 13-62.

${ }^{379}$ The Queen was Elizabeth I (1558-1603). The 'Low Countries' referred to the Netherlands. The Earl of Leicester was Robert Dudley (153288).
} 
- $\quad$ B Ayala, De Jure et Officiis Bellicis et Disciplina Militari (1582); ${ }^{380}$

- $\quad$ A Gentili, De Jure Belli (1588), ${ }^{381}$

- Markham, The Booke of Honour or Five Decades of Epistles of War (1622);

- M Sutcliffe, Practice, Proceedings and Laws of Arms described out of the doings of the most valiant Captains etc (1593). ${ }^{382}$

A review of the law martial may be found in McBain, Martial Law.

\section{Texts relating to Military Law: $1600-1700$}

Texts include the following:

- Law and Ordinances of War established for the good conduct of the service in Ireland (1638);

- Laws and Ordinances of War for the better government of his Majesty's Army Royal in the present expedition for the Northern Parts [i.e. Scotland] (1639) (pub. Earl of Arundel);

- $\quad$ Laws and Ordinances of War (1640) (pub. Earl of Northumberland);

- Articles and Ordinances of War for the Present Expedition of the Army of the Kingdom of Scotland (1643); ${ }^{383}$

- $\quad$ Laws of War and Ordinances of the Sea (1652);

- $\quad$ Abridgment of the English Military Discipline (1678);

- E Coke, Institutes of the Laws of England (4 vols, 1618-41); ${ }^{384}$

- F Negus, Necessary Abstract of Laws relating to the Militia (1691);

- J March, An Argument or Debate in Law of the Great Question concerning the Militia (1642);

- $\quad$ R Zouch, Descriptio Juris et Judicii Militaris nec non Maritimi (1652).

A review of the law martial may be found in McBain, Martial Law, see 2. Also, R Harford, English Military Discipline (1680).

\section{Texts relating to Military Law: $1700-1800$}

Texts include the following:

- $\quad$ Abridgment and Abstracts of the Laws relating to the Ordnance (1725);

- W Blackstone, Commentaries on the Laws of England (Clarendon Press, $1^{\text {st }}$ ed, 1765-9, Univ. of Chicago Press rep 1979);

- $\quad$ S Brewster, Jus Feciale Anglicanum or a Treatise of the Laws of England relating to War and Rebellion (1725);

- $\quad$ A Bruce, The Institutions of Military Law, Ancient and Modern (1717);

- $\quad$ R Burn, Digest of the Militia Laws (1760);

- Law Military or a Methodical Collection of the Laws relating to the Army and Soldiery of Great Britain and also of the Navy Royal (1719);

- $\quad$ M Hale, Prerogatives of the King (1976), Selden Society, vol 92;

- J Hardestry, Militia Law (1st ed, 1718; $2^{\text {nd }}$ ed, 1814);

- $\quad$ G Sharp, Four Tracts concerning the Ancient and only true legal means of National Defences by a Free Militia (1782);

- $\quad$ RJ Sullivan, Thoughts on Martial Law (1784);

- AF Tytler, Essay on Military Law and the Practice of Military Courts Martial (1 $1^{\text {st }}$ ed, 1800). ${ }^{385}$

A review of the law martial may be found in McBain, Martial Law, see 2.

\section{Texts relating to Military Law: $1800-1850$}

Texts include the following:

- $\quad$ Admiralty, Queen's Regulations for the Government of HM Naval Service (1844);

- C Bynkershoek, Law of War (trans Du Ponceau)(1810); 386

- $\quad$ FRA Griffith, Military Law, Proceedings of Court Martial etc (1841);

\footnotetext{
${ }^{380}$ Translated, JB Bate, Three Books on the Law of War and the Duties connected with War and Military Discipline (1912).

${ }^{381}$ For translation, see SJ Rolfe, De Jure Belli Libri Tres [with the Translation] (Oxford, 1933). Gentili (1552-1608), Regius Professor at Oxford in 1587, also produced De Armis Romanis (1590-9).

${ }^{382}$ Matthew Sutcliffe [1550-1629], Dean of Exeter, may have served as a chaplain with the forces of the Earl of Essex. Hence, his knowledge of military law. Excepts of his text have been published by B Heuser, The Strategy Makers: Thoughts on War and Society from Machiavelli to Clausewitz (2010).

${ }^{383}$ See The Harleian Miscellany (1811), vol 7, pp 475-9. See also J Bryson, Articles of Militarie Discipline (Edinburgh, 1639). Also, An Abridgment of the English Military Discipline (1684).

${ }^{384}$ For a modern edition of Coke see that of 1824 (last ed, 5 vols), re-published by the Law Book Exchange.

${ }^{385} \mathrm{Jl}$ Brierly (trans), R Zouche, An Exposition of the Fecial Law and Procedure or of the Law between Nations and Questions concerning the Same (1912). 'Fecial' (Fetial) related to the Roman law relating to declarations of war and peace.

${ }^{386}$ See PS Du Ponceau, A Treatise on the Law of War (Translated from the original Latin of Cornelius van Bynkershoek) (1810, republished by Law Book Exchange).
} 
- $\quad$ FA Griffiths, Notes on Military Law (1841);

- W Hough, Mutiny Acts and Articles of War etc (1838);

- W Hough, Chronological Exposition of Military Law deduced from the different writers from 1731-1838 (1839);

- W Hough, Precedents in Military Law (1855);

- $\quad$ CJ Napier, Military Law and Flogging (1837);

- $\quad$ RB Rowe, Reports of Interesting Cases in the King's law courts of England and Ireland, the Houses of Parliament and Military Courts with a treatise on Martial Law (1824);

- $\quad$ E Samuel, Historical Account of the British Army $\left(1^{\text {st }}\right.$ ed, 1816; $2^{\text {nd }}$ ed, 1820);

- $\quad$ RB Scott, Military Law of England (1810).

\section{Texts relating to Military Law: 1850-1900}

Texts include the following:

- $\quad$ A de M Bidoulac, Orders in Council relating to Deserters, Fugitive Offenders etc (1887);

- $\quad$ WA Burn \& WT Raymond, Law regulating the Volunteer Forces (1882);

- $\quad$ P Burke, Celebrated Naval and Military Trials (1865);

- $\quad$ CM Clode, The Military Forces of the Crown, their Administration and Government (1869);

- $\quad$ CM Clode, The Administration of Justice under Military and Martial Law ( $\left(1^{\text {st }}\right.$ ed, $1872 ; 2^{\text {nd }}$ ed, 1874);

- $\quad$ CM Clode, Statutory Powers of Her Majesty's Principal Secretary of State for the War Dept, Ordnance Branch (1879);

- $\quad$ E Dwyer, Compendium of Militia Laws (1857);

- WF Finlason, Treatise on Martial Law (1866);

- $\quad$ WF Finlason, Commentaries upon Martial Law (1867);

- $\quad$ E Gunter, Outlines of Military Law and Customs of War (1897);

- $\quad$ Manual of Military Law ( $1^{\text {st }}$ ed $1884 ; 8^{\text {th }}$ ed, 1952-3);

- $\quad$ JK Pipon \& JF Collier, Manual of Military Law (1 $1^{\text {st }}$ ed 1860; last ed ( $\left.3^{\text {rd }}\right) 1865$ );

- $\quad$ SC Pratt, Military Law: Its Procedure and Practice ( $1^{\text {st }}$ ed, 1883; last ed $\left(19^{\text {th }}\right.$ ed), 1915);

- $\quad$ H Prendergast, Law relating to Officers in the Army $\left(2^{\text {nd }}\right.$ ed, 1855$)$;

- $\quad$ H Prendergast, Law relating to Officers in the Army (1855);

- $\quad$ TW Saunders, Militia Law (4 $4^{\text {th }}$ ed, 1855);

- $\quad$ PF Shortland, Account of the Laws which govern the Navy (1887);

- $\quad$ P Story, Summary of Military Law and Procedure (1886);

- $\quad$ HB Thomas, Military Force and Institutions of Great Britain and Ireland (1855);

- $\quad$ T Thring, Criminal Law of the Navy $\left(1^{\text {st }}\right.$ ed; 1861 ' $2^{\text {nd }}$ ed, 1877);

- H Tovey, Military Law (1887);

- $\quad$ GJ Wheeler, Foreign Enlistment Act [1870] (1896);

- W Winthrop, Military Law and Precedents ( $2^{\text {nd }}$ ed, 1896).

\section{Texts relating to Military Law: $1900-25$}

Texts of military legislation include the following:

- Admiralty, King's and Queen's Regulations and Admiralty Instructions (1916 (2 vols)-1953 (1 vol);

- Admiralty, Memorandum on Naval Court Martial containing Naval Discipline Act and other Statutes, Naval Court Martial Regulations etc (1910, 1937);

- $\quad$ Air Ministry, King's and Queen's Regulations and Air Council Instructions for the Royal Air Force (1st ed 1924; $3^{\text {rd }}$ ed, 1953);

- $\quad$ Defence of the Realm. Manual of Emergency Legislation (1st ed 1914, last ed, 1919);

- Manual of Air Force Law (1918, rep in 1933 and amended in 1939 \& 1949);

- $\quad$ Munitions of War Acts, Appeals from Tribunals (1916-20, 4 vols).

Also,

- JWS Armstrong, War and Treaty Legislation affecting British property in Germany and Austria and enemy property in the United Kingdom (1922);

- $\quad$ H Baker, Law relating to the Territorial Force (1909);

- $\quad$ WA Burn, Claims against the Military (1903);

- $\quad$ C Cook, Defence of the Realm Manual (1918)

- $\quad$ JA Hall, Law of Naval Warfare (2 ${ }^{\text {nd }}$ ed, 1921); 
- $\quad$ WH Stoker \& H Bentwich, The Military Service Acts Practice (1918);

- $\quad$ R O'Sullivan, Military Law and the Supremacy of the Civil Courts (1921);

- JR Wilkins \& WS Chaney, Handbook of Military Law (1930).

\section{Texts relating to Military Law: 1925-1950}

Texts include the following:

- $\quad$ Air Ministry, King's Regulations and Air Council Instructions as applied to the Women's Royal Air Force (1949);

- J Baker, The Law of Political Uniforms, Public Meetings and Private Armies (1937);

- $\quad$ ST Banning, Military Law (1946);

- J Burke, War Damage Guide (1943);

- J Burke, Encyclopedia of War Damage and Compensation (1941-52);

- J Burke, War Legislation (1939-49);

- $\quad$ FJO Coddington, Young Officer's Guide to Military Law (1940);

- $\quad$ FJO Coddington, Young Officer's Guide to Air Force Law (1942);

- Defence Regulations (21 ${ }^{\text {st }}$ ed, 1954, in force 27 December 1953);

- $\quad$ O'Sullivan, Military Law and the Supremacy of the Civil Courts (1921);

- $\quad$ R Schless, The Reserve and Auxiliary Forces (Protection of Civil Interests) Act 1951 (1951);

- $\quad$ W Senior, Naval History of Law Courts (1927);

- $\quad$ GG Slack and MM Wells, Liability for National Service (2 $2^{\text {nd }}$ ed, 1943);

- $\quad$ T Stephens, Practical Digest of Military Law (1933);

- JR Wilkins \& WS Chaney, Handbook of Military Law (1930).

10. Texts relating to Military Law: 1950

Texts include the following:

- Ministry of Defence (MOD), Manual of Military Law (1 ${ }^{\text {st }}$ ed 1884, last ed (2 pts), 1992).*
- MOD, Manual of Naval Law (2005); *
- MOD, Manual of Armed Conflict (2004); *
- MOD, Manual of Air Force Law (1994); *

- $\quad$ MOD, Manual of Service Law (JSP 830, 2011); ${ }^{387}$

- $\quad$ MOD, The Joint Service Manual of the Law of Armed Conflict (JSP, 383, 2004 with amendments); ${ }^{388}$

- JW Rant, Rant on the Court Martial and Service Law (3 ${ }^{\text {rd }}$ ed, 2009, J Blackett) $3^{389}$

- $\quad$ A Duxbury (ed), Military Justice in the Modern Age (2016);

- $\quad$ APV Rogers, Law on the Battlefield ( $3^{\text {rd }}$ ed, 2013).

[* See now JSP 830 \& P 383]

There are also various legal texts dealing with specialised areas of military law, viz. the following:

\section{Courts Martial}

- $\quad$ Admiralty Court Martial Procedure (Admiralty Memorandum on) (1954);

- $\quad$ SP Adye, Courts Martial ( $1^{\text {st }}$ ed, 1769 ; last ed ( ${ }^{\text {th }}$ ed $\left.), 1810\right)$;

- $\quad$ ST Banning, Military Law made Easy $\left(1^{\text {st }}\right.$ ed, 1901; $22^{\text {nd }}$ ed, 1942);

- WA Burn, Claims against the Military (1903);

- $\quad$ CF Colville, Military Tribunals (1883);

- $\quad$ WF Cox, Guide to Preparation of Cases for District Courts-Martial and Proceedings (1st ed, 1917; last ed 1919);

- $\quad$ G D'Aguilar, Observations on the Practice and the Forms of District, Regimental and Detachment Courts Martial $\left(1^{\text {st }}\right.$ ed 1843 ; last ed $\left.\left(7^{\text {th }}\right), 1868\right)$;

- $\quad$ W Delafon, Naval Courts Martial (1805);

- $\quad$ FRA Griffith, Military Law, Proceedings of Court Martial etc (1841);

- $\quad$ D Hannay, Naval Courts Martial (1914);

- $\quad$ W Hickman, Law and Practice of Naval Courts Martial (1851);

\footnotetext{
387 The are other publications which sit alongside JSP 830

${ }^{388}$ There have been 7 amendments to JSP 383 and a new version will (likely) soon appear.

${ }^{389}$ The $2^{\text {nd }}$ ed had the title 'Courts-Martial, Discipline and the Criminal Process in the Armed Services.'
} 
- W Hough, Precedents in Military Law, including the Practice of Courts Martial (1855);

- W Hough, Practice of Courts Martial (3rd ed, 1835);

- $\quad$ RM Hughes, Duties of Judge Advocates (1845);

- C James, Collection of the Charges, Opinions and Sentences of General Courts Martial from 1795 (1820);

- V Kennedy, Proceedings of General Courts-Martial etc (1825);

- $\quad$ R Liddell, Detail of the Duties of Deputy Judge Adviocate (1805);

- J M'Arthur, Treatise of the Principle and Practice of Naval and Military Courts Martial ( $1^{\text {st }}$ ed, 1792; $3^{\text {rd }}$ ed, 1813);

- O'Beirne, Considerations on the Principles of Naval Discipline and Naval Courts Martial (1781);

- $\quad$ GR Rubin, Murder,Mutiny and the Military: British Court Martial Cases 1940-66 (2005);

- $\quad$ TF Simmons, Constitution and Practice of Courts Martial ( $1^{\text {st }}$ ed, 1843; last ed ( $\left.\left.7^{\text {th }} \mathrm{ed}\right), 1875\right)$;

- $\quad$ HL Stephen \& R Townshend-Stephens, A Digest of the Law of Evidence in Courts Martial (1934);

- JER Stephens et al, Manual of Naval Law and Court Martial Procedure (1 $1^{\text {st }}$ ed, 1901; last ed (4th ed) 1912);

- $\quad$ GW Treadwell, Military Courts Manual (1945);

- $\quad$ AF Tytler, Essay on Military Law and the Practice of Military Courts Martial ( $1^{\text {st }}$ ed, 1800; last ed ( $3^{\text {rd }}$ ed) 1812$)$;

- AF Tytler, Collection of Charges, Opinions and Sentences of Courts Martial from 1795 (1820).

The modern law of courts-martial commenced with the Army Act 1881. Thus, the above legal texts are of historical interest only.

\section{Prize Law}

- $\quad$ TH Acton, Reports of Cases of Appeals in Prize Causes (1811-2);

- $\quad$ T Baty, Prize Law and Continuous Voyage (1915);

- $\quad$ CJ Colombos, Law of Priz e ( ${ }^{\text {rd }}$ ed, 1949);

- $\quad$ A Croke, Remarks on Mr Schlegel's Visitation of Neutral Vessels under Convoy (1801);

- $\quad$ TE Holland, Manual of Naval Prize Law (1888);

- $\quad$ H Hull, Digest of Cases decided in British Prize Courts (1927);

- $\quad$ DI Katchenovsky, Prize Law (trans FT Pratt) (2 $2^{\text {nd }}$ ed, 1867);

- $\quad$ WB Lawrence, Visitation and Search (1858);

- $\quad$ Lloyd's, Reports of Prize Cases (1915-24);

- $\quad$ G Lushington, Naval Prize Law (1866);

- JF Macqueen, Laws of War and Neutrality, Search and Blockade (1862);

- JF Potts, Observations on Matters of Prize and the Practice of the Admiralty Prize Court (1810);

- $\quad$ ES Roscoe, History of the Admiralty Court and Prize Court ( $\left(2^{\text {nd }}\right.$ ed, 1932);

- $\quad$ ES Roscoe, Lord Stowell, His Life and Development of English Prize Law (1916);

- $\quad$ ES Roscoe, Reports of Prize Cases 1745 to 1859 (1905);

- $\quad$ HC Rothery, Prize Droits, a Report of HM Treasury on Droits of the Crown and Admiralty in War (1915);

- JY Searlett, Memorandum to the Presidents of all District and General Courts-Martial (1865);

- JFV Schlegel, Upon the Visitation of Neutral Vessels under Convoy (1801);

- $\quad$ T Spinks, Reports, Admiralty Prize Court and Court of Appeal (1854-6);

- J Story, Notes on the Principles and Practice of the Prize Courts (ed FT Pratt) (1854);

- $\quad$ Tiverton (Visc), Principles and Practice of Prize Law (1914);

- $\quad$ ECM Trehern \& AW Grant, British and Colonial Prize Cases (1916-22);

- $\quad$ T Twiss, Belligerent Rights on the High Seas (1877);

- $\quad \mathrm{H}$ Wheaton, Enquiry into the Validity of the British Claim to a Right of Visitation and Search of American Vessels suspected to be engaged in the African Slave Trade (1858);

- $\quad$ R Wildman, Law of Search and Capture and Prize (1854).

On these matters see GS McBain, Modernising the Law of Prize (2014) Journal of Business Law, no 6, pp 465-83 which article asserts that the law of prize (and bounty) - if not abolished - should be modernised and simplified.

\section{Martial Law, Billeting, Conscription}

Legal texts include:

- C Butler, Legality of Impressing Seamen (1760);

- $\quad$ WG Hartin, Law and Practice of Military Conscription under Military Service Acts 1916-18 (1917-8). 
See also McBain, Martial Law ${ }^{390}$ and GS McBain, Abolishing Obsolete Crown Prerogatives relating to the Military (2011) Nottingham LJ, vol 20, pp 14-37..$^{391}$

\section{Court of Chivalry}

On the Court of Chivalry (also, called the Court of the Earl Marshall), useful texts are:

- $\quad$ G Grazebrook, The Earl Marshall's Court in England (1895);

- $\quad$ GD Squibb, The Law of Arms in England (1953).

On this court, see also GS McBain, Abolishing various Obsolete Courts (2012) Coventry LJ, vol 17, no 1, pp 25-55. ${ }^{392}$

\section{Saltpetre, Letters of Marque \& Murage}

On saltpetre, see the articles by McBain mentioned in 13. ${ }^{393}$ Letters of Marque and Reprisal were a form of Crown licensed privateering as opposed to piracy. They were obsolete by 1820. Murage was a toll imposed for the repair of city and town walls, for defensive (military) purposes. It is long obsolete (since 1688, at least, given the changing nature of warfare).

\section{Castellation \& Military Fortifications}

The Crown has a prerogative to castellate (that is, to build castles or fortified residences). Further, it (often) franchised the same in medieval times. ${ }^{394}$ Both the prerogative - and any franchise - are now obsolete. The Crown also has the right to enter private land belonging to a subject, to erect military fortifications. On these matters, see GS McBain, Expanding Democracy - Transferring the Crown Prerogative to Parliament (2014), Review of European Studies, vol 6, no 1, pp 1-44 and GS McBain, Modernising English Land Law (2019) ILR, vol 8, no 1, p 123.The prerogative to castellate is now obsolete (a castle would need planning permission anyway). The ability to requisition land for military purposes is now statutory.

\section{Law of War}

For legal texts which relate to military law generally (including from an international perspective), see Sweet and Maxwell, A Legal Bibliography of the British Commonwealth (1955-7, see above). The Crown prerogative to declare war and peace is considered in the first article of McBain referred to in $\mathbf{1 6 .}$

NOTE: Many of the articles by McBain referred to above are available online for free.

\section{Copyright}

Copyright for this article is retained by the author(s), with first publication rights granted to the journal.

This is an open-access article distributed under the terms and conditions of the Creative Commons Attribution license (http://creativecommons.org/licenses/by/4.0/).

\footnotetext{
${ }^{390}$ See $\mathrm{n} 43$. This article asserts that the Crown prerogative to impose martial law (i.e. to subject civilians to military law) should be abolished since legislation now governs the matter (Civil Contingencies Act 2004). Further, the whole purpose of subjection to military law was to impose harsher punishments (the death penalty, flogging etc) which punishments have been abolished.

${ }^{391}$ These articles assert that the Crown prerogative (power) to impress for the navy (it was no longer applied after 1814) and for the army (it was, always, more restricted and on a more dubious legal basis) should be abolished since legislation governed the matter in WW I and II. In other words, (conscription) legislation superceded the prerogative. Further, that the Crown prerogative to billet members of the armed forces on the public should also be abolished since it was superceded by legislation (Army Act 1955 etc).

${ }^{392}$ The article asserts that the Court of Chivalry should be abolished and its civil powers ( $r e$ armorial matters) should be assumed by the High Court (its military powers are now long obsolete since distinct military courts martial were established by legislation).

${ }^{393}$ The right of the Crown to dig for saltpetre (potassium nitrate) on private land is unnecessary and should be abolished (the use of saltpetre was obsolete by the $19^{\text {th }}$ century at the latest).

${ }^{394}$ Castellation (from castellatio, the erection of a castle) has no mention in Anglo-Saxon times, see B Thorpe, Ancient Laws and Institutes of England (1840, glossary) (castellatio). However, the Crown asserted such a right (and the need to obtain licence) by c. 1113, see Downer, $\mathrm{n}$ 217, p 117 ('construction of fortifications without permission').
} 